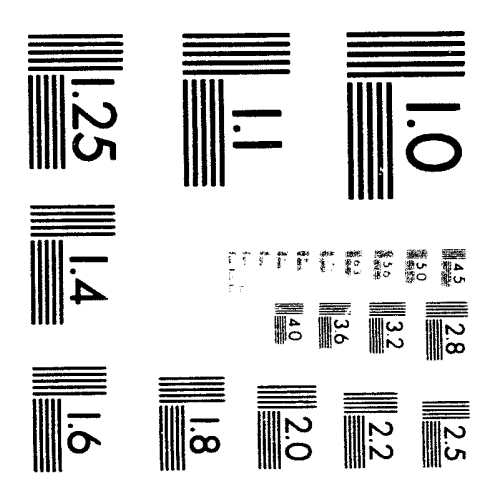




\title{
Drinking Water Program 1992 Annual Report
}

\author{
Brad D. Andersen \\ Laurie J. Peterson-Wright \\ Published August 1993 \\ Idaho National Engineering Laboratory \\ EG\&G Idaho, Inc. \\ Idaho Falls, Idaho 83415
}

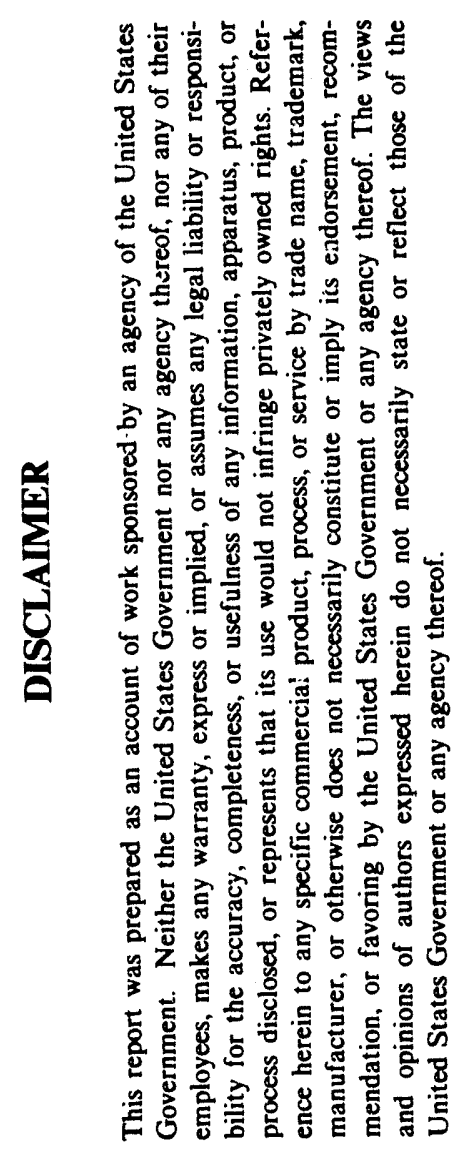

Prepared for the

U.S. Department of Energy

Assistant Secretary for Environmental

Restoration and Waste Management

Under DOE Idaho Operations Office

Contract DE-AC07-761D01570 


\begin{abstract}
EG\&G Idaho, Inc., initiated a monitorin/s progran for drinking water in 1988 for the U.S. Department of Energy at the Idaho National Engineering Laboratory. EG\&G Idaho structured this monitoring program to ensure that they exceeded the minimum regulatory requirements for monitoring drinking water. This program involves tracking the bacteriological, chemical, and radiological parameters that are required for a "community water system" (maximum requirements). This annual report describes the drinking water monitoring activities conducted at the 17 EG\&G Idaho operated production wells and 11 distribution systems. It also contains all of the drinking water parameters that were detected and the regulatory limits that were exceeded during 1992. In addition, ground water quality is discussed as it relates to contaminants identified at the wellhead for EG\&G Idaho production wells.
\end{abstract}




\section{SUMMARY}

The Drinking Water Program (DWP) annual report will focus on drinking water used at the Idaho National Engineering Laboratory (INEL). In addition, ground water quality will be discussed as it relates to the contaminants identified at the wellhead for EG\&G Idaho production wells. The goal of the EG\&G Idaho DWP is to comply with Envirormental Protection Agency (EPA) and State of Idaho regulations, as well as applicable DOE orders.

Sampling is performed under the direction of EGi\& Idaho's Environmental Monitoring (EM) Unit DWP. This program monitors all drinking water at EG\&G Idaho operated facilities located at the INEL. During 1992, personnel conducted drinking water sampling at 17 EG\&G Idaho operated production wells and 11 distribution systems.

The drinking water parameters sampled for in 1992 are monitored once every three years in accordance with community water system standards. These parameters are listed in the Idaho Regulations for Public Drinking Water Systems [Administrative Procedures Act (IDAPA) 16.01. 08100,01.,04., and 12.] Semiannual monitoring for lead and copper was initiated in accordance with 40 CFR 141.80 through 141.90 during May and September of 1992. As of June 7, 1991, the lead and copper rule replaced the existing interim maximum contaminant level (MCL) of $0.050 \mathrm{mg} / \mathrm{L}$ for lead with a treatment technique action level of $0.015 \mathrm{mg} / \mathrm{L}$. Also, proposed parameters for future regulations were monitored to help prevent future noncompliance issues.

Drinking water was monitored and analyzed for bacteriological, radiological, and chemical constituents. Sampling was conducted at production wellheads and distribution systems. The following production wells and distribution systems were sampled:

- Central Facilities Area (CFA) \#1 well, \#2 well, and distribution system
- Main Gate well and distribution system

- Power Burst Facility (PBF) \#1 well, \#2 well, and distribution system

- Experimental Breeder Reactor I (EBR-I) well and distribution system

- Gun Range well and distribution system

- Fire Station \#2 well and distribution system

- Test Reactor Area (TRA) \#1 well, \#3 well, \#4 well, and distribution system

- Test Area North/Test Support Facility (TAN/TSF) \#1 well, \#2 well, an d distribution system

- $\quad$ TAN/Containment Test Facility (TAN/CTF) \#1 well, \#2 well, and distribution system

- $\quad$ TAN/Water Reactor Research Test Facility (WRRTF) well and distribution system

- Radioactive Waste Management Complex (RWMC) well and distribution system.

The State of Idaho and EPA require laboratories to be State of Idaho certified for drinking water analyses or have reciprocity with the State of Idaho (IDAPA 16.01.08100,10). The following laboratories were used for drinking water analyses:

- Montgomery Laboratory, located in Pasadena, California, conducted the chemical analyses.

- Alpha Analytical Laboratory, located in Sparks, Nevada, conducted the volatile organic compound analyses (monthly/quarterly).

- Accu-Lab Research, located in Golden, Colorado, conducted radiological analyses for tritium (quarterly).

- Lockheed Analytical Laboratory, located in Las Vegas, Nevada, conducted the lead and copper analyses (semiannual). 
- Radiological and Environmental Sciences Laboratory (RESL), located at CFA-690, conducted monthly radiological analyses. Their data provide information for ground water quality assessment and the INEL Environmental Surveillance Program.

- The EG\&G Idaho Environmental Hygiene Laboratory, located at CFA-612, conducted monthly bacteriological analyses.

- District 7 Health Department, located in Idaho Falls, conducted bacteriological analyses.

Note: Since the EPA audited both RESL and District 7 Health Department for laboratory certification for drinking water analyses, EG\&G Idaho did not audit these two laboratories.

This annual report lists all drinking water parameters that were detected and the regulatory limits that were exceeded during 1992. The samples were analyzed using approved EPA drinking water methods as listed in the Code of Federal Regulations (40 CFR Parts 141-143). All data undergo technical review, data evaluation, and data assessment before being reported.

Maximum contaminant levels are levels established for primary drinking water standards by EPA Standards. The only parameters that were exceeded for 1992 were trichloroethylene (TCE) at the inactive water system of TAN/WRRTF and coliform bacteria at PBF (June and Novemher), TRA (August and December), TAN/CTF (July and September), and TAN/TSF (July and August). TCE levels at the TAN/WRRTF system have remained constant since they were first detected in 1988. This well is used only to monitor water quality. Personnel at TAN/WRRTF use bottled water, and all drinking fountains have been taken out of service and posted as nonpotable.

Investigations at TAN/TSF, TRA, and PBF where transition phase for determining the source of coliform bacteria have been completed and the actual source of the contamination could not be determined. The information obtained indicates that the coliform bacteria is related to water line deterioration from the older water systems at the INEL and stagnant water. Since TAN and PBF personnel work four ten-hour days, the water system is essentially not used from Thursday evening to Monday morning thus allowing bacteria to build up within the water systems. After the water systems containing the coliform bacteria were flushed, the test results were negative for coliform bacteria (that is, no coliform bacteria present).

In 1988, water samples collected at the wellhead of the TAN/TSF \#1 well exceeded the MCL established for TCE. A sparger system was installed into the TAN/TSF water system to reduce the TCE concentration to acceptable limits. The sparger system has corrected the excessive TCE concentrations and the water system is safe for drinking water.

Sample results from TAN/TSF \# I well are used for ground water quality assessment only and not for drinking water compliance purposes. Samples are collected from the distribution system to demonstrate compliance with the State of Idaho Drinking Water Regulations. Maximum contaminant level limits for TCE have not been exceeded since 1988 in the distribution system.

The data in this report have met the quality assurance objectives of the program (see Appen$\operatorname{dix}$ A). Laboratories that were used during 1992 successfully passed a quality assurance and technical audit before samples were submitted to them. 


\section{ACKNOWLEDGMENTS}

The author gratefully wishes to acknowledge and thank all those who contributed to the preparation of this report: Robert J. Sheehan, Rod D. Grant, Cindy A. Neal, and Dave A. Anderson for technical review, data evaluation, and data assessment; Maurice McLain, Vince E. Daniel and Environmental Monitoring personnel for assisting in the sample collection and preparation; Gerald A. Harris for statistics; Electronic Publications--Site for formatting and proofreading; and Ralph E. Clark for compiling the information, editing, and coordinating the work of the author and text editor to ensure timely completion of this document. 


\section{CONTENTS}

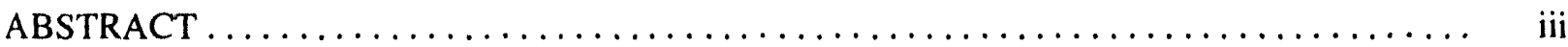

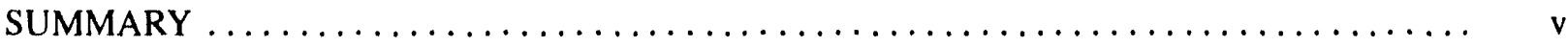

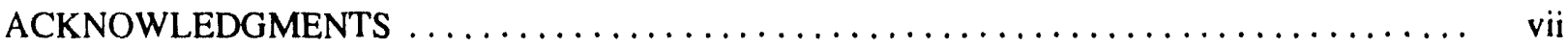

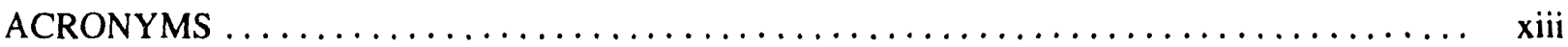

INTRODUCTION $\ldots \ldots \ldots \ldots \ldots \ldots \ldots \ldots \ldots \ldots \ldots \ldots \ldots \ldots \ldots \ldots \ldots \ldots \ldots$

REGIJLATIONS $\ldots \ldots \ldots \ldots \ldots \ldots \ldots \ldots \ldots \ldots \ldots \ldots \ldots \ldots \ldots \ldots \ldots \ldots \ldots$

SAMPLE COLLECTION PROCEDURES $\ldots \ldots \ldots \ldots \ldots \ldots \ldots \ldots \ldots \ldots \ldots \ldots \ldots$

WELLS AND DISTRIBUTION SYSTEMS AND DISCUSSION OF RESULTS $\ldots \ldots \ldots \ldots \ldots$

General Sampling Information $\ldots \ldots \ldots \ldots \ldots \ldots \ldots \ldots \ldots \ldots \ldots \ldots \ldots \ldots \ldots \ldots$

Locations and Summary of Results $\ldots \ldots \ldots \ldots \ldots \ldots \ldots \ldots \ldots \ldots \ldots \ldots$

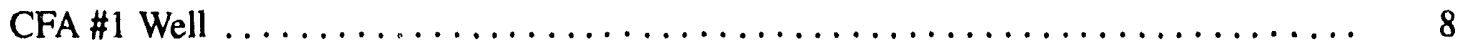

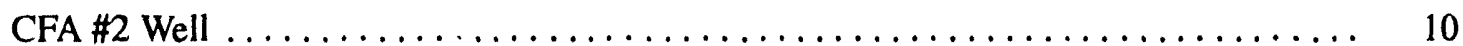

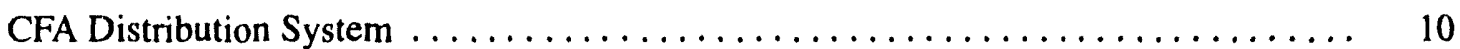

Main Gate Well and Distribution System ........................ 11

PBF\#1 Well ......................................... 11

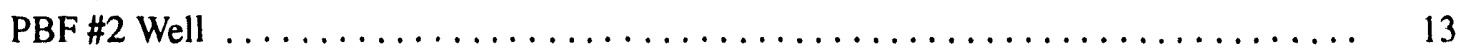

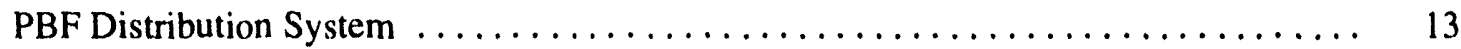

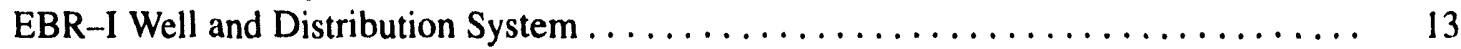

Gun Range Well and Distribution System $\ldots \ldots \ldots \ldots \ldots \ldots \ldots \ldots \ldots \ldots \ldots \ldots$

Fire Station $\# 2$ Well and Distribution System $\ldots \ldots \ldots \ldots \ldots \ldots \ldots \ldots \ldots \ldots \ldots$

TRA \#1 Well ........................................... 16

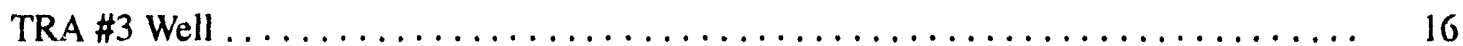

TRA \#4 Well .......................................... 16

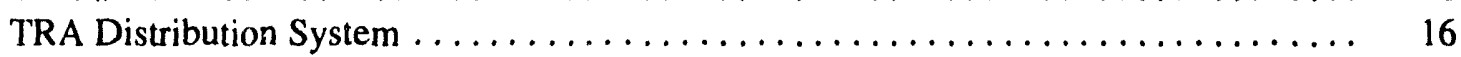

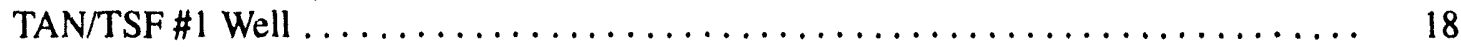

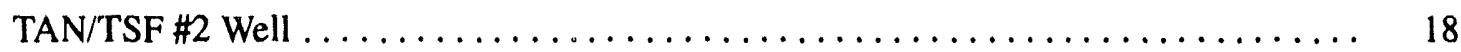

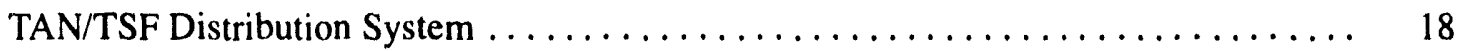

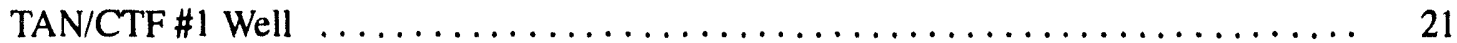

TAN/CTF \#2 Well .................................. 21

TAN/CTF Distribution System ............................. 21

TAN/WRRTF Well ................................... 23

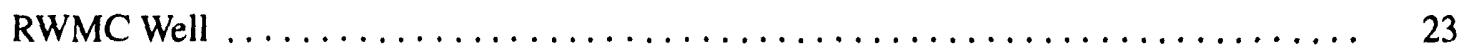

RWMC Distribution System ............................ 23

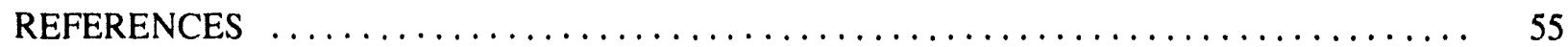

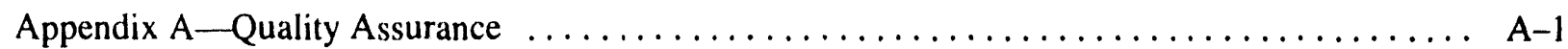

Appendix B-EG\&G Idaho Facilities Water Distribution Systems and Production Well Descriptions $\ldots \ldots \ldots \ldots \ldots \ldots \ldots \ldots \ldots \ldots \ldots \ldots$, B-1 


\section{FIGURES}

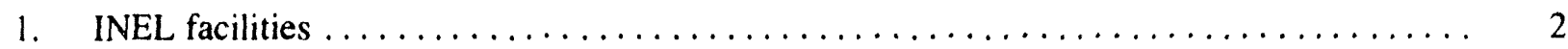

2. Sample collector recording applicable information in the field logbook $\ldots \ldots \ldots \ldots \ldots$

3. Collection of a drinking water sample $\ldots \ldots \ldots \ldots \ldots \ldots \ldots \ldots \ldots \ldots \ldots \ldots$

4. Plot plan of CFA showing the locations of CFA- 651 and $-642 \ldots \ldots \ldots \ldots \ldots \ldots$

5. Monthly concentrations of tritium in CFA drinking water during $1992 \ldots \ldots \ldots \ldots \ldots$

6. Plot plan showing approximate location of the Main Gate well, B27-605 $\ldots \ldots \ldots \ldots$

7. Plot plan of PBF showing the location of PBF-602 and the approximate location of

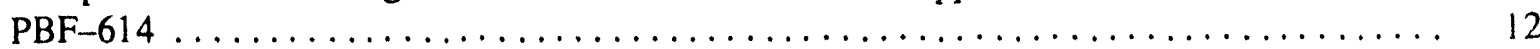

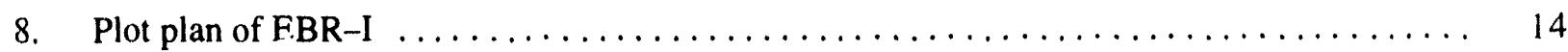

9. Plot plan of the Gun Range showing the location of B21-607 $\ldots \ldots \ldots \ldots \ldots \ldots \ldots \ldots$

10. Plot plan of TRA showing the locations of TRA $-601,-650$, and $-672 \ldots \ldots \ldots \ldots \ldots$

11. Plot plan of TAN/TSF showing the locations of TAN-610, -612 , and $-613 \ldots \ldots \ldots \ldots$

12. Sparger system installed in the water storage tank at TAN/TSF distribution system,

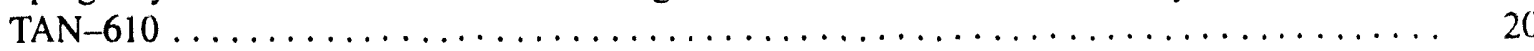

13. Monthly concentrations of TCE in TAN/TSF drinking water during $1992 \ldots \ldots \ldots \ldots$

14. Plot plan of TAN/CTF showing the locations of TAN-632 and $-63 \ldots \ldots \ldots \ldots \ldots \ldots 22$

15. Plot plan of TAN/WRRTF showing the location of TAN-645 $\ldots \ldots \ldots \ldots \ldots \ldots \ldots \ldots$

16. Plot plan of RWMC showing the location of WMF- $603 \ldots \ldots \ldots \ldots \ldots \ldots \ldots \ldots$

17. Monthly concentrations of carbon tetrachloride in RWMC drinking water during $1992 \ldots \ldots 26$

\section{TABLES}

1. List of parameters analyzed for calendar year $1992 \ldots \ldots \ldots \ldots \ldots \ldots \ldots \ldots \ldots$

2. Pertinent drinking water regulatory codes and orders $\ldots \ldots \ldots \ldots \ldots \ldots \ldots \ldots \ldots$

3. Parameters for EG\&G Idaho production wells and distribution systems found to be above the EPA and State of Idaho MCLs for $1992 \ldots \ldots \ldots \ldots \ldots \ldots \ldots \ldots \ldots \ldots \ldots \ldots$

4. 1992 regulated VOCs detected and average concentrations $\ldots \ldots \ldots \ldots \ldots \ldots \ldots \ldots \ldots$

5. 1992 average radiological concentrations from RESL $\ldots \ldots \ldots \ldots \ldots \ldots \ldots \ldots \ldots$ 
6. Results of detected radiological parameters of the drinking water analyses for samples collected at the CFA \#1 well, CFA-651; CFA \#2 well, CFA-642; and distribution system, CFA-641

7. Results of detected nonradiological parameters of the drinking water analyses for samples collected at the CFA \#1 well, CFA-651; CFA \#2 well, CFA-642; and

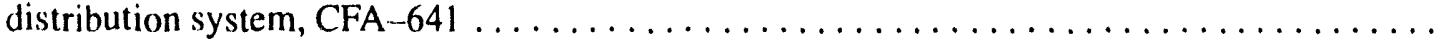

8. Results of the lead and copper sampling at CFA during May and September of $1992 \ldots \ldots .35$

9. Results of detected radiological parameters of the 1992 drinking water analyses for

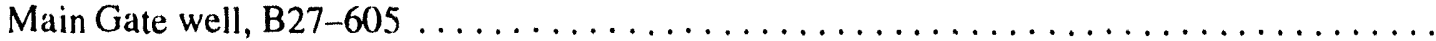

10. Results of detected nonradiological parameters of the 1992 drinking water analyses for Main Güte distribution system, B27-603

11. Results of the lead and copper sampling at the Main Gate during May and September of 1992

12. Results of detected radiological parameters of the drinking water analyses for

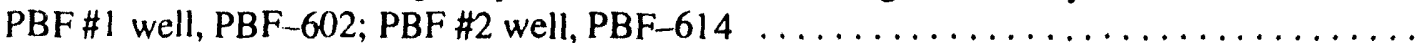

13. Results of detected nonradiological parameters of the drinking water analyses for PBF distribution system, PBF-602 .............................

14. Results of the lead and copper sampling at PBF during May and September of $1992 \ldots \ldots \ldots$

15. Results of detected radiological parameters of the drinking water analyses for

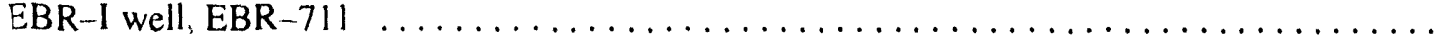

16. Results of detected nonradiological parameters of the drinking water analyses for EBR-I distribution system, EBR-601

17. Results of the lead and copper sampling at EBR-I during May and September of $1992 \ldots \ldots$

18. Results of detected radiological parameters of the drinking water analyses for

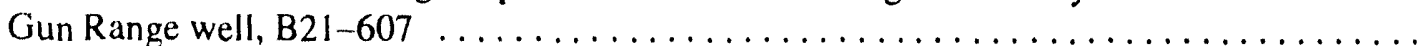

19. Results of detected nonradiological parameters of the drinking water analyses for the

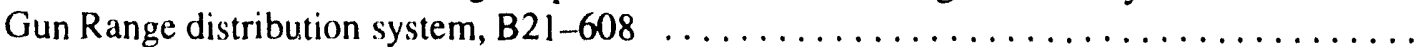

20. Results of lead and copper sampling at the Gun Range distribution system during

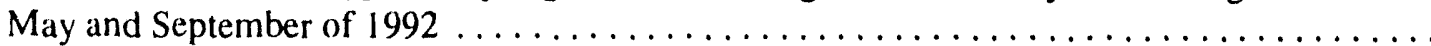

21. Results of detected radiological parameters of the drinking water analyses for the

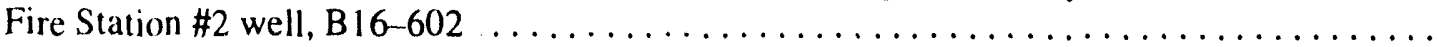

22. Results of detected nonradiological parameters of the drinking water analyses for Fire Station \#2 distribution system, B16-601 .......................

23. Results of detected radiological parameters of the drinking water analyses for the TRA \#1 well, TRA-601; TRA \#3 well, TRA-650; TRA \#4 well, TRA-672; and distribution system, TRA-608 
24. Results of detected nonradiological parameters of the drinking water analyses for

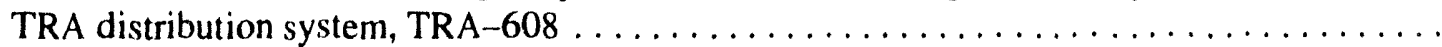

25. Results of lead and copper sampling at the TRA distribution system during May and September of 1992

26. Results of detected radiological parameters of the drinking water analyses for TAN/TSF \#1 well, TAN-612; TAN/TSF \#2 well, TAN-613

27. Results of detected nonradiological parameters of the drinking water analyses for the TAN/TSF \#1 well, TAN-612; TAN/TSF \#2 well, TAN-613; and distribution system,

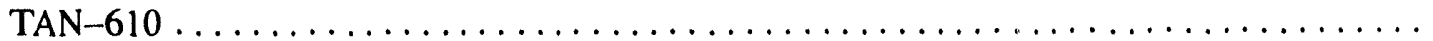

28. Results of lead and copper sampling at the TAN/TSF distribution system during May

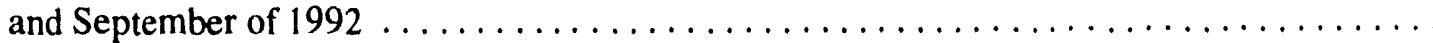

29. Results of detected radiological parameters of the drinking water analyses for TAN/CTF \#1 well, TAN-632; TAN/CTF \#2 well, TAN-639 ..............

30. Results of detected nonradiological parameters of the drinking water analyses for

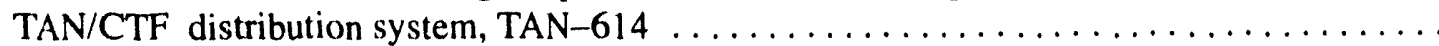

31. Results of lead and copper sampling at the TAN/CTF distribution system during

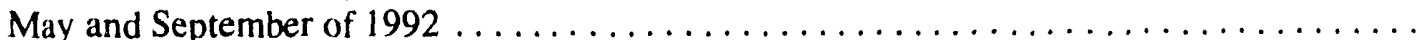

32. Results of detected radiological parameters of the drinking water analyses for TAN/WRRTF well, TAN-644

33. Results of detected nonradiological parameters of the drinking water analyses for TAN/WRRTF distribution system, TAN-645

34. Results of detected radiological parameters of the drinking water analyses for RWMC well, WMF-603

35. Results of detected nonradiological parameters of the drinking water analyses for RWMC well and distribution system, WMF-603

36. Results of lead and copper sampling at the RWMC distribution system during May and September of 1992 


\section{ACRONYMS}

\begin{tabular}{|c|c|c|c|}
\hline ALR & Accu-Lab Research & OMRE & $\begin{array}{l}\text { Organic Moderate Reactor } \\
\text { Experiment }\end{array}$ \\
\hline CFA & Central Facilities Area & & \\
\hline FR & Code of Federal Regulations & PBF & Power Burst Facility \\
\hline & & PCE & tetrachloroethylene \\
\hline CT & carbon tetrachloride & QA & quality assurance \\
\hline CTF & Containment Test Facility & RESI & \\
\hline CY & calendar year & ע & Sciences Laboratory \\
\hline DOE & U.S. Department of Energy & RSD & Relative Standard Deviation \\
\hline DOE-ID & $\begin{array}{l}\text { U.S. Department of Energy Idaho } \\
\text { Operations Office }\end{array}$ & RWMC & $\begin{array}{l}\text { Radioactive Waste Management } \\
\text { Complex }\end{array}$ \\
\hline DWP & Drinking Water Program & SDWA & Safe Drinking Water Act \\
\hline EBR-I & Experimental Breeder Reactor I & SMCL & $\begin{array}{l}\text { secondary maximum contaminant } \\
\text { level }\end{array}$ \\
\hline EHL & Environmental Hygiene Laboratory & & curty Training Facilities \\
\hline $\mathrm{EM}$ & Environmental Monitoring & Sin & 200 \\
\hline EPA & Environmental Protection Agency & TAN & Test Area North \\
\hline ESRP & Eastern Snake River Plain & TCA & 1,1,1-trichloroethane \\
\hline ICPP & Idaho Chemical Processing Plant & TCE & trichloroethylene \\
\hline IDAPA & Idaho Administrative Procedures Act & TTHM & total trihalomethane \\
\hline INEL & Idaho National Engineering & TRA & Test Reactor Area \\
\hline & Laboratory & TSF & Test Support Facility \\
\hline LAL & Lockheed Analytical Laboratory & VOC & volatile organic compound \\
\hline MCL & maximum contaminant level & WRRTF & Water Reactor Research Test Facilit \\
\hline
\end{tabular}




\section{Drinking Water Program 1992 Annual Report}

\section{INTRODUCTION}

The Snake River Plain aquifer, approximately $320 \mathrm{~km}(200 \mathrm{mi})$ long and 32 to $97 \mathrm{~km}$ (20 to $60 \mathrm{mi}$ ) wide, comprises an area of about $25,000 \mathrm{~km}^{2}\left(9650 \mathrm{mi}^{2}\right)$, and is the source of groundwater that underlies the Eastern Snake River Plain (E:RP). The aquifer may contain as much as $2.5 \times 10^{12} \mathrm{~m}^{3}\left(2 \times 10^{9} \mathrm{acre}-\mathrm{ft}\right)$ of water. Discharges of approximately $8 \times 10^{9} \mathrm{~m}^{3}$ $\left(6.5 \times 10^{6}\right.$ acre- $\left.\mathrm{ft}\right)$ occur annually through springs in the Hagerman area, upstream from American Falls Reservoir and through irrigation well withdrawals. Discharges from the springs make a significant contribution to the flow of the Snake River downstream from Twin Falls, Idaho. Aquifer recharge occurs mostly from infiltration of ground irrigation water $\left(6.3 \times 10^{9} \mathrm{~m}^{3}\right.$, $5.1 \times 10^{6}$ acre-ft) and from valley underflow from the recharge area to the north and northeast of the ESRP $\left(1.9 \times 10^{9} \mathrm{~m}^{3}, 1.5 \times 10^{6}\right.$ acre-ft). ${ }^{1}$ Other contributions are from river seepage $\left(1.6 \times 10^{9} \mathrm{~m}^{3}, 1.3 \times 10^{6}\right.$ acre-ft) and infiltration of precipitation $\left(1.0 \times 10^{9} \mathrm{~m}^{3}, 0.6 \times 10^{6} \mathrm{acre}-\mathrm{ft}\right)$.

The depth to the Snake River Plain aquifer varies from $61 \mathrm{~m}(200 \mathrm{ft})$ in the northeast corner of the Idaho National Engineering Laboratory (INEL) to $270 \mathrm{~m}(900 \mathrm{ft})$ in the southeast corner. The thickness of the aquifer is considered to be approximately $76 \mathrm{~m}(250 \mathrm{ft}){ }^{2}$ Ground water in the aquifer flows generally to the southwest, although locally the direction of flow is influenced by recharge from rivers, surface water spreading areas, and heterogeneities in the aquifer. Tracer studies at the INEL indicate that natural flow rates range from 1.5 to $6.1 \mathrm{~m} / \mathrm{d}(5$ to $20 \mathrm{ft} / \mathrm{d}$ ). Aquifer transmissivities range from $3.7 \times 10^{5}$ to $2.2 \times 10^{8} \mathrm{~L} / \mathrm{d} / \mathrm{m}\left(3 \times 10^{4}\right.$ to $1.8 \times 10^{7} \mathrm{gal} / \mathrm{d} / \mathrm{ft}$ ); storage coefficients range from 0.01 to $0.06 .^{3}$

In 1988, in response to a U.S. Department of Energy Idaho Operations Office (DOE-ID) request, EG\&G Idaho, Inc., established an INEL Drinking Water Program (DWP). This program was established for sampling production wells and distribution systems on a routine schedule at facilities operated by EG\&G Idaho. The DWP was structured to ensure that EG\&G Idaho exceeded the minimum regulatory requirements for monitoring drinking water systems. Under the Idaho Regulations for Public Drinking Water Systems [Idaho Administrative Procedures Act (IDAPA) 16.01.08003,32.], ${ }^{4}$ EG\&G Idaho drinking water systems are classified as "nontransient, noncommunity water systems." Regulations for such systems are less stringent than those required for "community water systems." However, EG\&G Idaho has taken a proactive approach to water monitoring by adopting the more stringent regulations of a community water system classification. Regulations governing the DWP are discussed in greater detail in the Regulation section of this document.

Currently, the DWP monitors 17 wells and 11 distribution systems on a routine schedule at the INEL (see Figure 1 for a map of the INEL). Monthly or quarterly drinking water samples are collected from all water systems and are analyzed for the following: (a) radiological contamination, (b) volatile organic compounds (VOCs), (c) coliform bacteria, and (d) other chemical parameters.

Quarterly monitoring was conducted for total trihalomethanes (TTHM) at the CFA water system. TTHM monitoring is required for community water systems that chlorinate their water.

In addition, semiannual monitoring was initiated in 1992 for lead and copper levels, according to EPA's requirements (40 CFR 141.80 to 141.91). As of June 7, 1991, the lead-and-copper rule replaced the existing interim maximum contaminant level (MCL) of $0.050 \mathrm{mg} / \mathrm{L}$ for lead with a treatment technique action level of $0.015 \mathrm{mg} / \mathrm{L}$. 

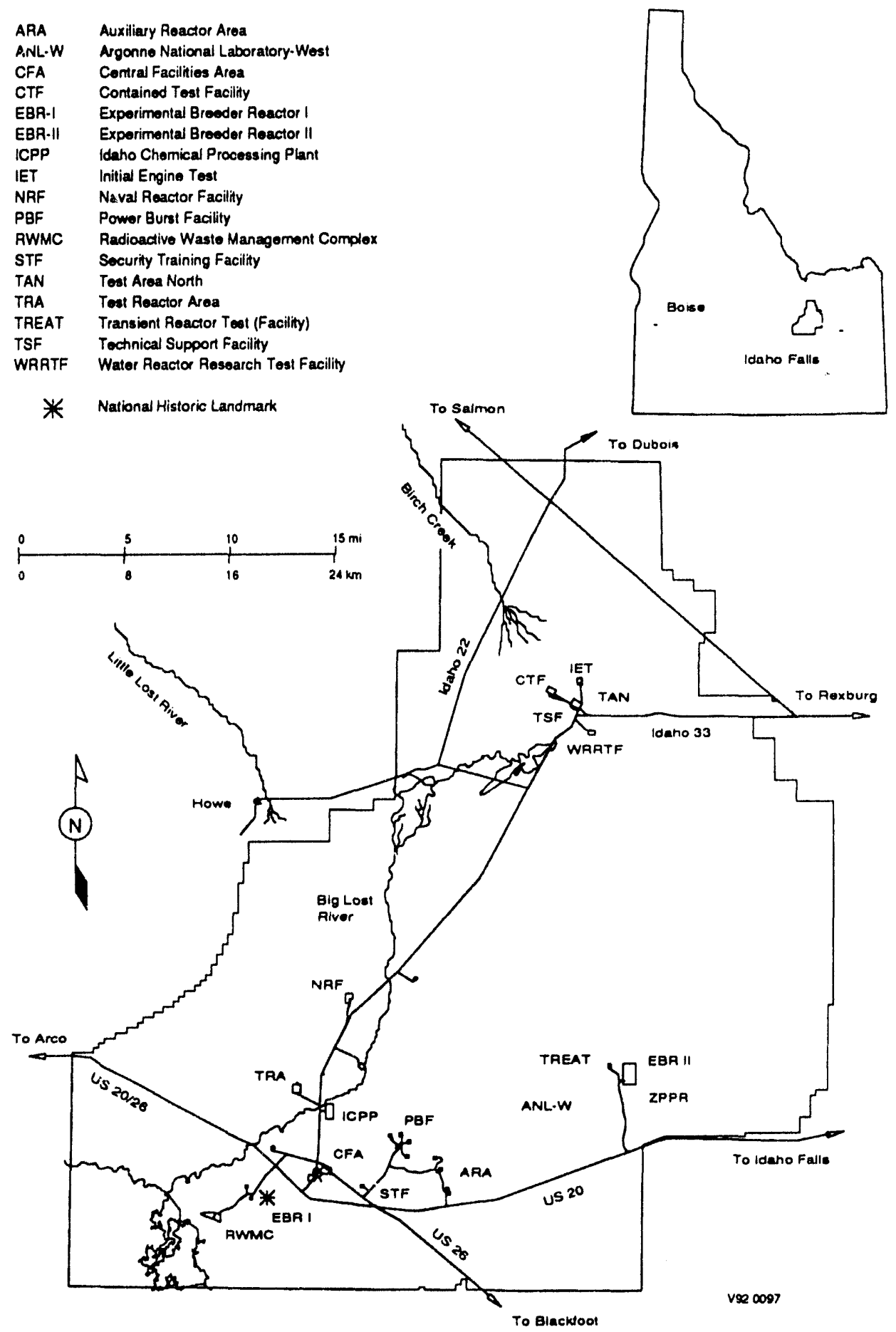

Figure 1. INEL facilities. 
Monthly water samples are collected and analyzed for gross alpha and beta radioactivity and tritium contamination. Radiological analyses are performed by the DOE's Radiological Environmental Sciences Laboratory (RESL), located at CFA-690. RESL provides the certified bottles for water sample collection and sends the sample analysis results to the DWP for ground water quality assessment purposes, as well as the INEL Environmental Surveillance Program.

The State of Idaho requires that drinking water analysis be conducted by a State of Idaho certified laboratory or a laboratory with reciprocity status with the State (IDAPA 16.01.08100,10.). ${ }^{4}$ Therefore, Accu-Lab Research (ALR) in Denver, Colorado, analyzed samples collected in 1992 for tritium at the CFA wells and distribution system. ALR has reciprocity with the State of Idaho for radiological drinking water analysis, and their samples are used for compliance purposes.

All ALR sample analysis results have been comparable to RESL's sample analysis results. All samples analyzed by ALR had radionuclide concentrations under the MCL for drinking water standards. Contamination levels for radiological parameters are determined by averaging laboratory results of drinking water samples from four consecutive quarters of monitoring. Drinking water analysis for radiological contaminants is required only once every four years for community water systems by the State of Idaho (IDAPA 16.01.08100,06.). ${ }^{4}$

The second set of contaminants monitored is VOCs. Samples to be analyzed for VOCs are collected quarterly from almost all active EG\&G Idaho water systems. The exception is the Test Area North/Test Support Facility (TAN/TSF), where trichloroethylene (TCE) has been detected. This water system is on a routine monthly sampling schedule and samples are submitted to Alpha Analytical Laboratory in Sparks, Nevada.

Samples analyzed for coliform bacteria are collected monthly and analyzed by the Industrial Hygiene Laboratory (IHL), located at CFA-612. Occasionally, District 7 Health Department conducts bacteriological analyses for EG\&G Idaho.
Sampling for chemical parameters is done monthly or quarterly, depending on the parameter of interest and regulatory requirements.

During 1992, the DWP collected samples that were an lyzed for organic parameters (herbicides, pesticides, and trihalomethane) listed in IDAPA $16.01 .08100,04$ and $12^{4}$ and also contaminants that may be regulated in the near future. These samples were sent to Montgomery Laboratory in Pasadena, California. See Table 1 for the list of parameters analyzed in 1992.

The results of the analyses performed by the Montgomery Laboratory were reported to the DWP. Personnel verified the accuracy and integrity of the data through a technical review, data evaluation, and data validation assessment.

In addition, Lockheed Analytical Laboratory (LAL) performed analyses for lead and copper, according to the regulations found in 40 CFR 141.80 to 141.90. Samples were collected May 18-22 and September 14-18, 1992.

The following production wells and distribution systems were sampled during 1992:

- Central Facilities Area (CFA) \#1 well, \#2 well, and distribution system

- Main Gate well and distribution system

- Power Burst Facility (PBF) \#1 well, \#2 well, and distribution system

- Experimental Breeder Reactor I (EBR-I) well and distribution system

- Gun Range well and distribution system

- Fire Station \#2 well and distribution system

- Test Reactor Area (TRA) \#1 well, \#3 well, \#4 well, and distribution system

- Test Area North/Test Support Facility (TAN/TSF) \#1 well, \#2 well, and distribution system

- TAN/Containment Test Facility (TAN/CTF) \#1 well, \#2 well, and distribution system

- TAN/Water Reactor Research Test Facility (WRRTF) well and distribution system

- Radioactive Waste Management Complex (RWMC) well and distribution system. 


\section{REGULATIONS}

The INEL is a U.S. Department of Energy (DOE) facility and is therefore required to comply with Federal, state, and site-specific regulations. These regulations include the Code of Federal Regulations (CFR), DOE and DOE-ID orders, Idaho regulations, and INEL site compliance requirements. Table 2 lists regulations that apply to the EG\&G Idaho EM Drinking Water Program.

Table 1 lists the primary drinking water parameters that are specified in the Idaho Regulations for Public Drinking Water Systems. For compliance purposes, samples are collected from the distribution system; and for ground water information, samples are collected from the wellhead. Therefore, all sampling points were not sampled for the complete set of parameters. See specific facility tables for details of specific pas imeters. Sampling for primary standards is required at least once every three years. Maximum contaminant levels are primary drinking water standards and are enforceable regulatory limits.
The Safe Drinking Water Act [40 CFR Part 141.61(a)(1) through (18) $]^{5}$ and the Idaho Regulations for Public Drinking Water Systems (IDAPA $16.01 .08900,03)^{4}$ presently list standards for regulated VOCs and additional unregulated VOCs 40 CFR Part 141.40 (see Table 1). The regulated VOCs have MCLs because of associated health problems at these concentration levels. At this time, the unregulated VOCs have no established regulatory limits. The regulated VOCs were analyzed using EPA Method 524.2 (revision 3). ${ }^{6}$

The INEL is a nuclear facility, which implies that radiological contamination of the drinking water is a possibility. Because of the possibility of radiological contaminants, EG\&G Idaho monitors for gross alpha and beta radioactivity and tritium as recommended for community water systems in the Idaho Regulations for Public Drinking Water Systems (IDAPA 16.01.08100,06). ${ }^{4}$ Radiological analysis of the drinking water samples is conducted by RESL, located at CFA-690, and ALR in Denver, Colorado. 


\section{SAMPLE COLLECTION PROCEDURES}

The DWP follows established procedures for sample collection and analytical methodology which includes the following: (a) use of standard operating procedures, which are based on EPA sampling protocols, (b) specific site training, (c) use of approved Environmental Protection Agency (EPA) analytical tnethods, (d) collecting quality control samples, and (e) conducting data validation.

Standard operating procedures were followed to ensure consistent collection of representative samples. The following is a description of the sampling techniques used and the quality control measures taken in accordance with DWP standard operating procedures. ${ }^{7}$

Sampling personnel wear a new pair of vinyl or latex gloves for each well and/or distribution system sampled to reduce the possibility of contaminating the samples during the collection process. Field measurements such as $\mathrm{pH}$, conductivity, and temperature are taken using a portable water quality detector.

Each day before the water quality detector is used, the detector is standardized as recommended by the manufacturer. This water quality detector is used to ensure that the water has stabilized before the collecting process begins. Readings are taken at the wellhead for 1-2 minute intervals until the readings are consistently within \pm 0.05 units for the $\mathrm{pH}$ and $\pm 10 \mu \mathrm{mhos} / \mathrm{cm}^{2}$ for conductivity. Consistent readings indicate the water has stabilized. When wells rather than distribution systems are being sampled, three well bore volumes are purged from the drinking water well prior to sample collection. This helps to ensure that the sample collected is representative of the water being analyzed.

The bottles used to collect the samples are purchased precleaned to EPA approved protocols A, $B$, or $C$ and inspected by Quality Inspectors ensuring that the bottles have been precleaned and are certified. The parameter of interest determines the bottle-type used and EPA cleaning protocol for each type. The bottles are documented with preassigned lot numbers ensuring traceability. Sampling personnel add preservative to the bottles that require preservation, to minimize biological and chemical degradation. Adding the preservative to the bottles before going into the field helps minimize contamination of the samples.

After the sampling is completed, each sample set is placed in its own cooler with blue ice or ice to preserve the sample, if required, until it reaches the laboratory. To ensure high quality sample collection and documentation, one sample team member collects the samples while the other sample team member records all applicable information about the sampling activities in the field logbook (see Figure 2).

Specific site training is required for collection of representative samples. Personnel are trained for sampling procedures and field quality control practices on a task-specific basis. ${ }^{7}$ The samples for this report were collected directly from the wellhead for ground water quality information and throughout the distribution system for compliance purposes.

Sampling person tel collect samples to be analyzed for radiologi al parameters from the wellhead and distributio: systems. Sampling from the wellhead provides infor nation about the ground water quality but would $n$, indicate contamination in the distribution system. Due to possible interference and bias that might be introduced by the pump and associated piping, these results may not be representative of the Snake River Plain aquifer. Sampling from the distribution system ensures that the quality of the drinking water that the personnel drink meets or exceeds health standards set forth by the regulatory agenties. 


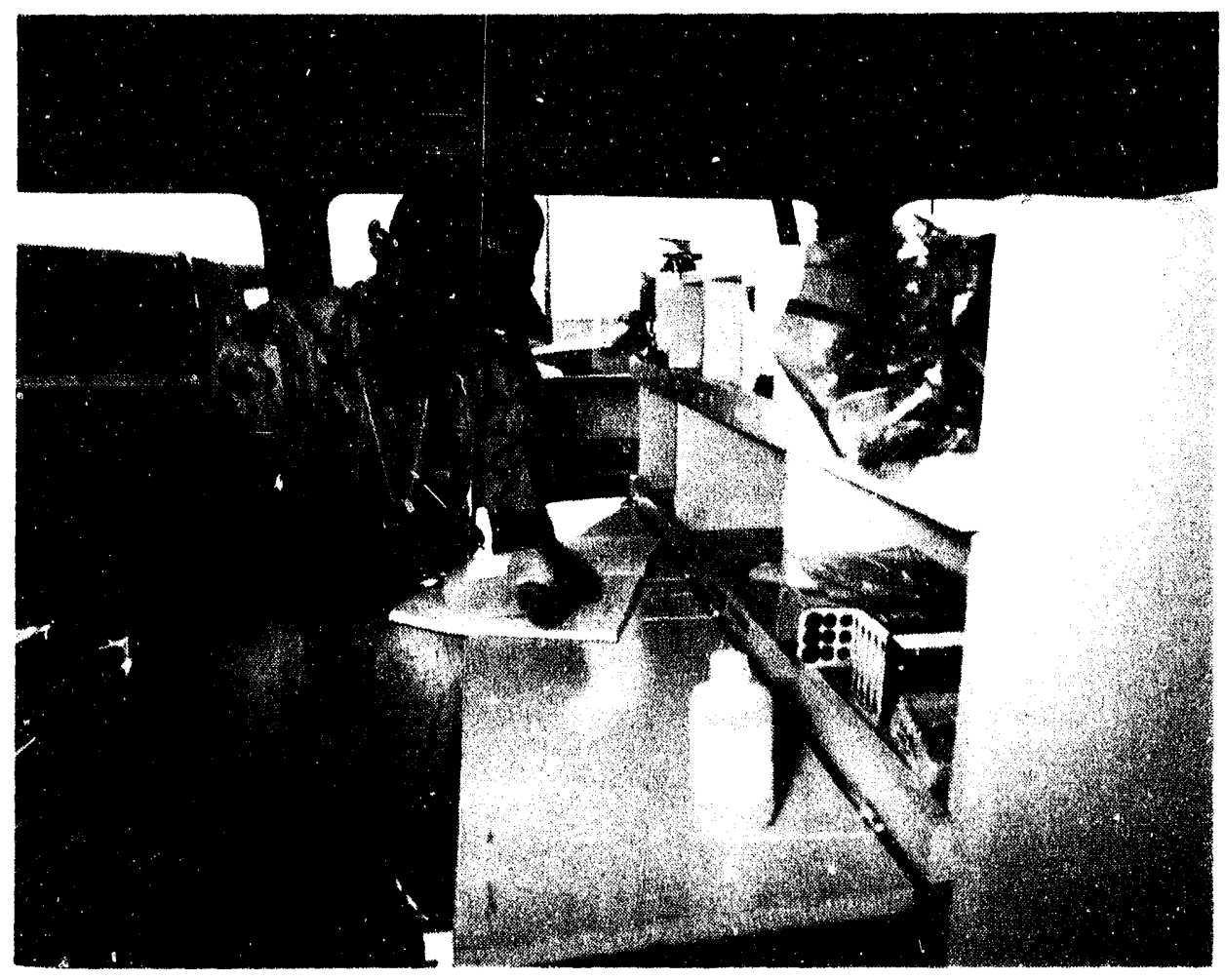

Figure 2. Sample collector recording applicate information in the field loghook.

Sampling for water qualiby parameters is done monthly, quaterly, or annually, depending on the parameter of interest and regulatory require ments. Fegre 3 shows the collecteon of a drink ing watce sample. All watter bystems in servate all leceli ldaho areas are sampled quarterly for $\checkmark(x)$ In addution. TTHMs were montered yuat

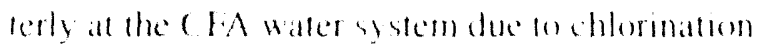
of thes system. Quartioly sampling was condected for organic dronking Water contamminnts listed in

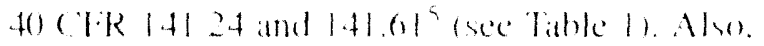
lead and copper were mommened for all tacier;

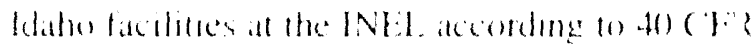
Pant 1.41.8016 1.41.91. Batctersolegteal sampling incomderked on a monthly sthedule lo ensure the water is safe tor human comsumpurom. Results of beth simpling and (juality assurance (Q) A analy ses ate stored into the dronking water monterme datablase. Contrate laterateres perform the and

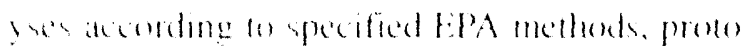

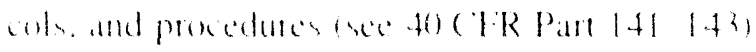

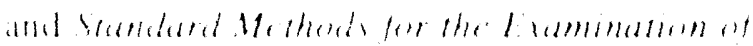

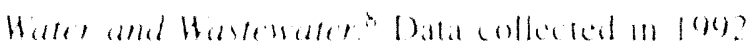
hase becen reporked to the State of ldature
The DWP uses H:PA approved analytical meth ods for drinhing water analyses in complance with IDAPA 16.01.0810(9).10. "These EPA methods have specifie detection limits and holding lumes that ane listed in 40) (PR Pant $141143^{5}$ and Standard Methods for the Eamination of Water and Wastewater. The Regulations sechon of thes decument lists the primary drinking water parameters of interest and the specific LPA meth. ods that were used for the analyes.

Quality control samples (duplacales trop blanks, and yphest are collected and eent as blend samples to ensure that bats does not enter into the analyses at the laboratory. The labosatory alow runs quality control samples as required by the EPA metheds. Quality control samples provide a check on the fiekl sampling lechnigues, sample shyment, and lateratory handling and analyses.

All data wed for complance purpeses is vall dited in accordante with the Drinking Witter Pro. geram Plan ohjectrese? Personnel as sgned w pertom data valdatson are howledgeable of

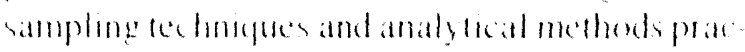
leced. 


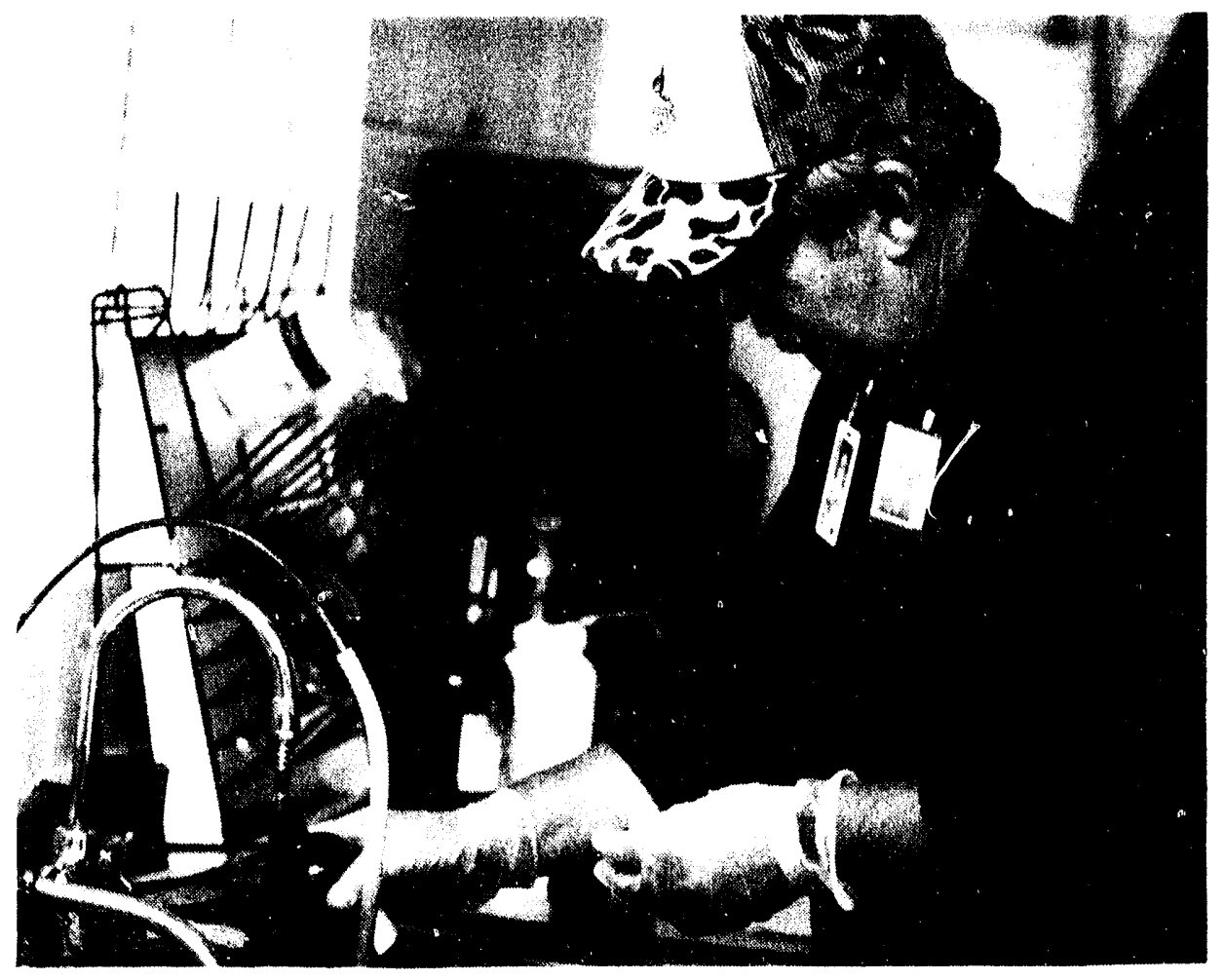

Figure 3. Collection of a driving water sample.

7 


\section{WELI.S AND DISTRIBUTION SYSTEMS AND DISCUSSION OF RESULTS}

\section{General Sampling Information}

The following sections describe the location of the 11 distribution systems and 17 INEL, EG\&G Idaho operated, drinking water wells that were sampled during 1992. These wells and distribution systems are located at: CFA, Main Gate, PBF, EBR-I, Gun Range, Fire Station (inactive), TRA, TAN, and RWMC.

The analytical results for each of the 17 wells and 11 distribution systems are also described and tabulated in the following subsections. See Appendix B for a detailed description of each production well.

During the quarterly organic sampling campaign, 10 drinking water distribution systems were sampled. Sampling occurred at the following water systems: EBR-1, Fire Station \#2, Main Gate, TAN/ CTF, Gun Range, RWMC-603, PBF, TRA, TAN/TSF, and CFA. The TAN/WRRTF distribution system was not sampled because it has been designated as an inactive water system.

Analytical results of the water samples collected during 1992 indicated that coliform bacteria and TCE were detected at concentrations exceeding the MCL established for each parameter (see Table 3).

Tatle 4 shows the VOC averages for EG\&G Idaho water systems detected in 1992. In addition to TCE, concentrations of tetrachloroethylene, trichloroethane, and carbon tetrachloride were detected but did not exceed the MCL established for each parameter. Radiological analyses results for gross alpha, gross beta, and tritium concentrations at each facility are listed in Table 5.

\section{Locations and Summary of Results}

\section{CFA \#1 Well}

The CFA \#1 well, located in CFA-651, is part of the CFA water system (see Figure 4). The CFA \#1 well is primarily used as a back-up system for CFA \#2 well and for fire protection. When CFA \#1 well is used, the water is mixed with CFA \#2 well water in the water storage tank before entering the distribution system. The CFA \#I well water is not chlorinated.

Th: CFA \#1 well was completed at a depth of $639 \mathrm{ft}$ with the water level at $468 \mathrm{ft}$ and has been in service since July 1942 . This well is equipped with a $150-\mathrm{hp}$, submersible pump and is capable of pumping water at 650 gallons per minute (gpm).

Water samples were collected at the CFA \# 1 well house for radiological analyses by RESL. Samples are collected for measuring ground water quality and not for compliance purposes. For compliance purposes, data obtained from the distribution system is used.

Figure 5 illustrates the monthly tritium concentrations. Tritium contamination in this well is believed to be due to previous disposal of waste water from 1952 until 1984 at the Idaho Chemical Processing Plant (ICPP) and from 1952 until 1982 at TRA. ${ }^{3}$ Tritium continues to be released into the groundwater via percolation ponds at ICPP and TRA.

The results of the detected parameters of the sample analyses for CFA \#1 well are listed in Tables 6 and 7. 


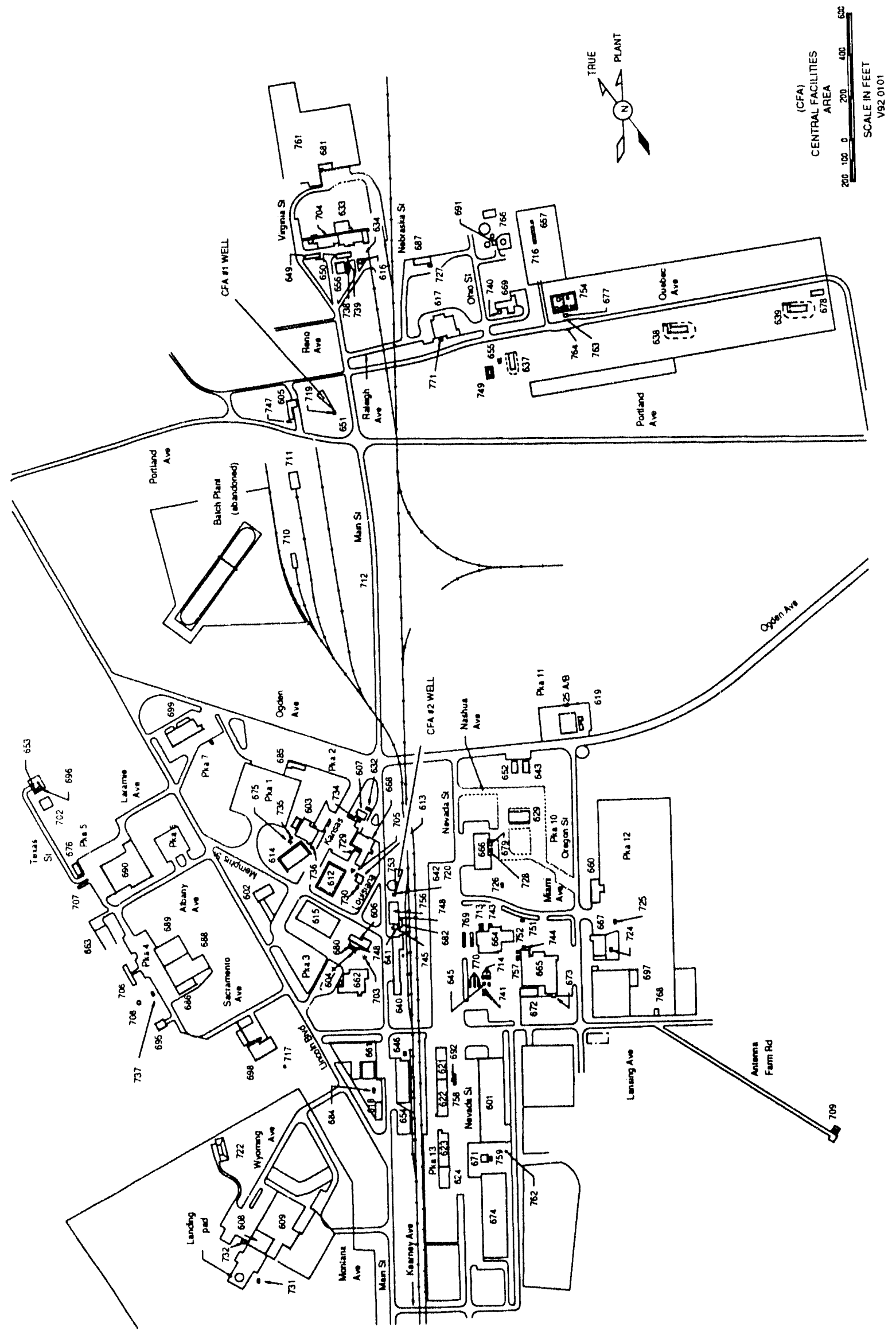

Figure 4. Plot plan of CFA showing the locations of CFA-651 and -642 . 


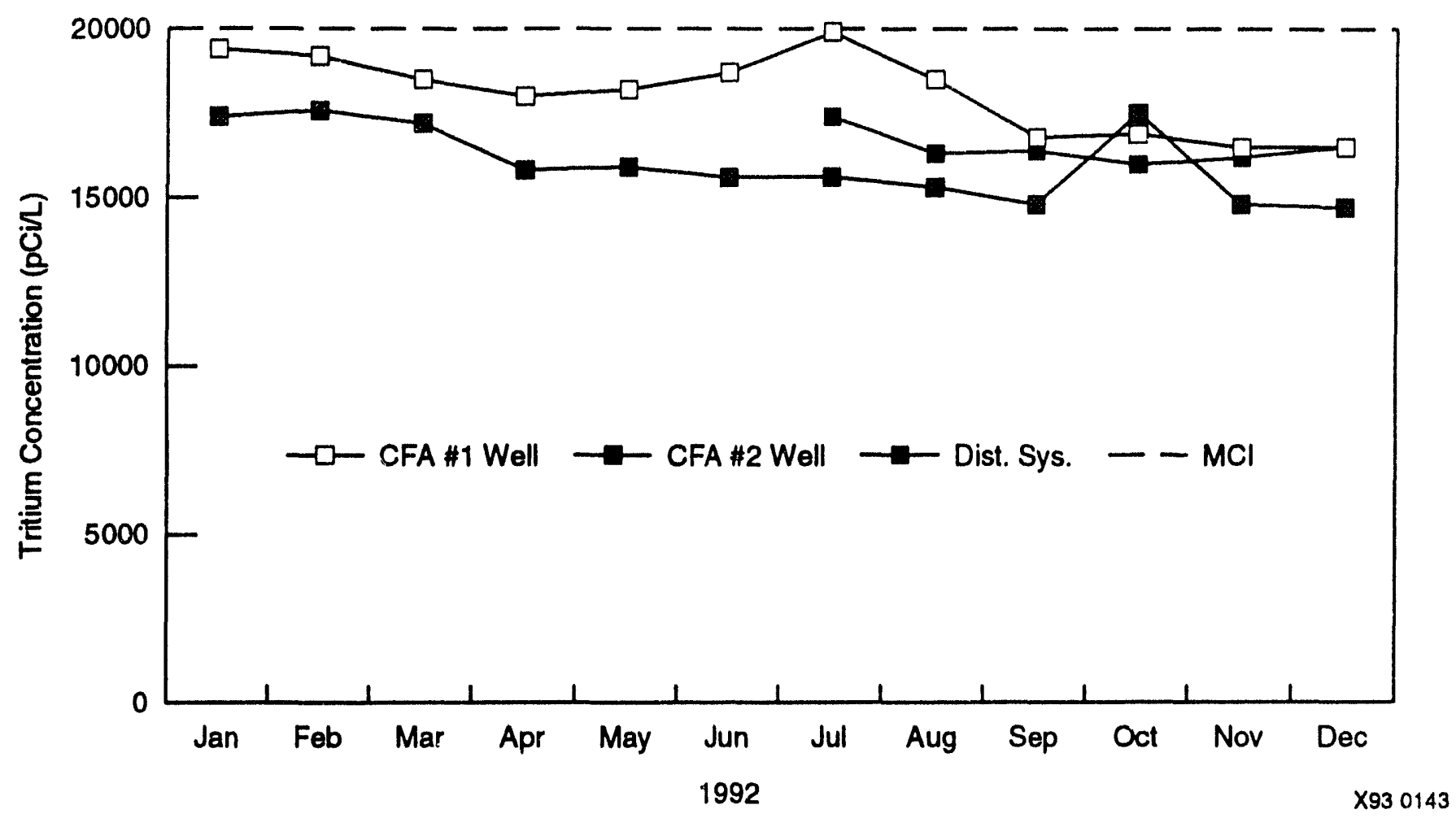

Figure 5. Monthly concentrations of tritium in CFA drinking water during 1992.

\section{CFA \#2 Well}

The CFA \#2 well, located in CFA-642, is a potable drinking water source and serves approximately 1500 people on a daily basis (see Figure 4). The well water is continuously disinfected with chlorine.

The CFA \#2 well was completed at a depth of $681 \mathrm{ft}$ with the water level at $471 \mathrm{ft}$ and has been in service since May 1944. This well is equipped with a 125-hp, submersible pump and is capable of pumping water at $600 \mathrm{gpm}$.

No parameters were detected at levels exceeding the Federal or State regulated MCLs at the CFA wells. Figure 5 illustrates the monthly tritium concentrations. Tritium contamination for this well is believed to enter into this system from the same sources described for the CFA \#1 well. The results of the 1992 drinking water analyses are listed in Tables 6 and 7.

\section{CFA Distribution System}

The CFA distribution system, located in CFA-641 was analyzed for the following parameters:

- Bacteriological (coliform bacteria), monthly on a rotated schedule to ensure each building was sampled at least once during the year

- TTHMs and VOCs, quarterly

- Gross alpha, beta, and tritium, monthly (from July to December) for RESL

- Tritium, quarterly by Accu-Lab

- Organic drinking water standards, quarterly (quarters 3 and 4 for 1992)

- Lead and copper, May and September of 1992.

The parameters detected in the CFA water system for 1992 are listed in Tables 6 and 7. Table 8 lists the results of the lead and copper sampling at 
CFA during May and September of 1992. No $\mathrm{MCL}$ drinking water standards were exceeded at the CFA wells or distribution systems for 1992 .

At the point of entry to the distribution system, RESL's mean average concentration of tritium was $16,470 \mathrm{pCi} / \mathrm{L}$ for 1992 . Results for samples sent to ALR indicated that the mean concentration at the point of entry to the distribution system for 1992 was $17,750 \mathrm{pCi} / \mathrm{L}$. Figure 5 illustrates the monthly tritium concentrations.

\section{Main Gate Well and Distribution System}

The Main Gate well, located in B27-605, which is the main entrance of the INEL, supplies drinking water to visitors and personnel (see Figure 6).
The Main Gate well was completed at a depth of $644 \mathrm{ft}$ with the water level at $489 \mathrm{ft}$ and has been in service since January 1985. This well is equipped with a 5-hp, submersible pump and is capable of pumping water at $20 \mathrm{gpm}$. The Main Gate well water is not chlorinated.

No Federal or State MCLs were exceeded at the Main Gate well or distribution system in 1992. This result is consistent with prior monitoring results. The results of the 1992 Main Gate well and distribution system drinking water analyses are listed in Tables 9, 10, and 11.

\section{PBF \#1 Well}

The PBF \#1 well, located in PBF-602, is one of two wells that supply water to the PBF area (see Figure 7). There are approximately 120 people using the $\mathrm{PBF}$ water system.

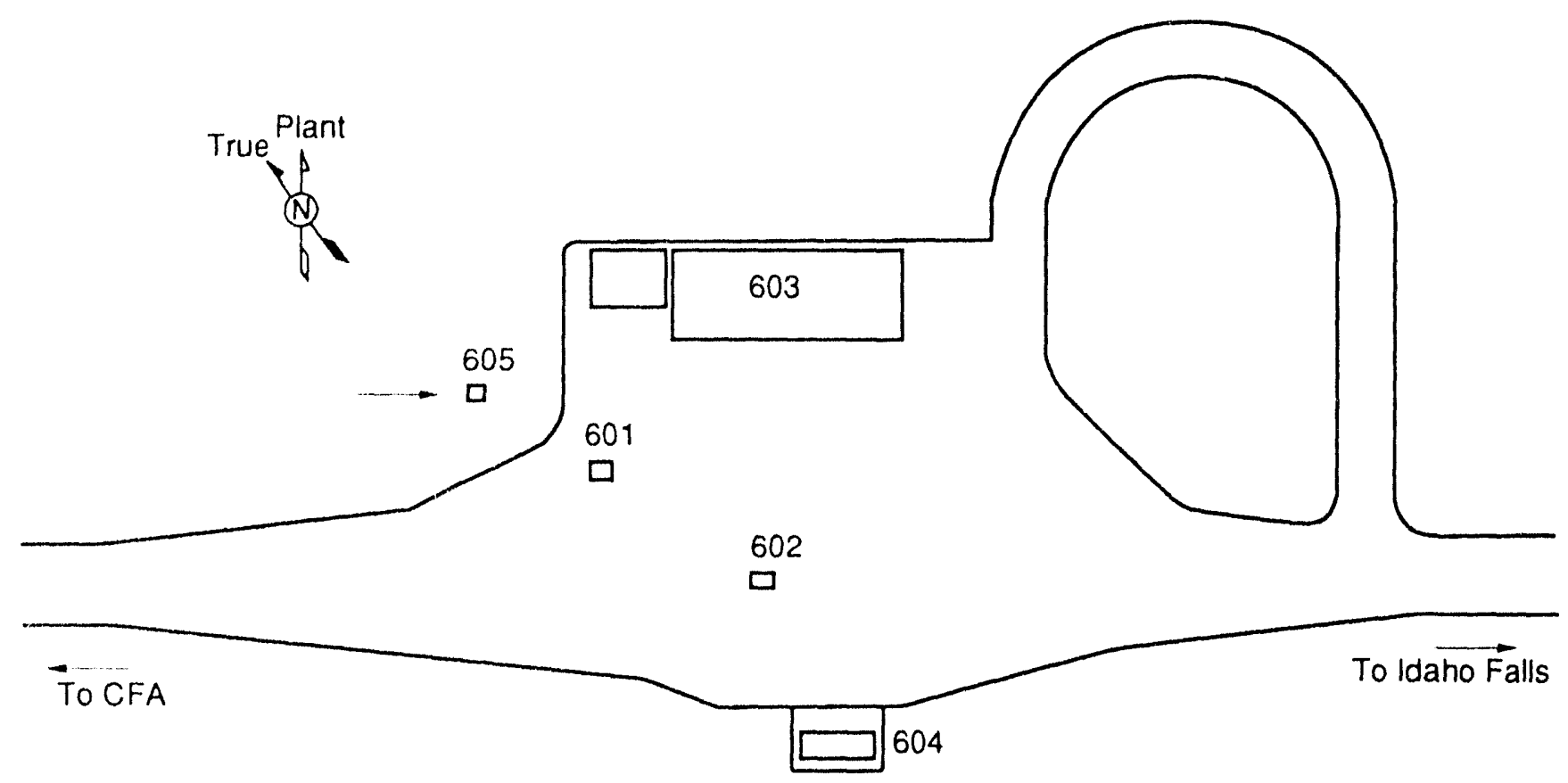

V920024

B27 Main Gate

Figure 6. Plot plan showing approximate location of the Main Gate well, B27-605. 


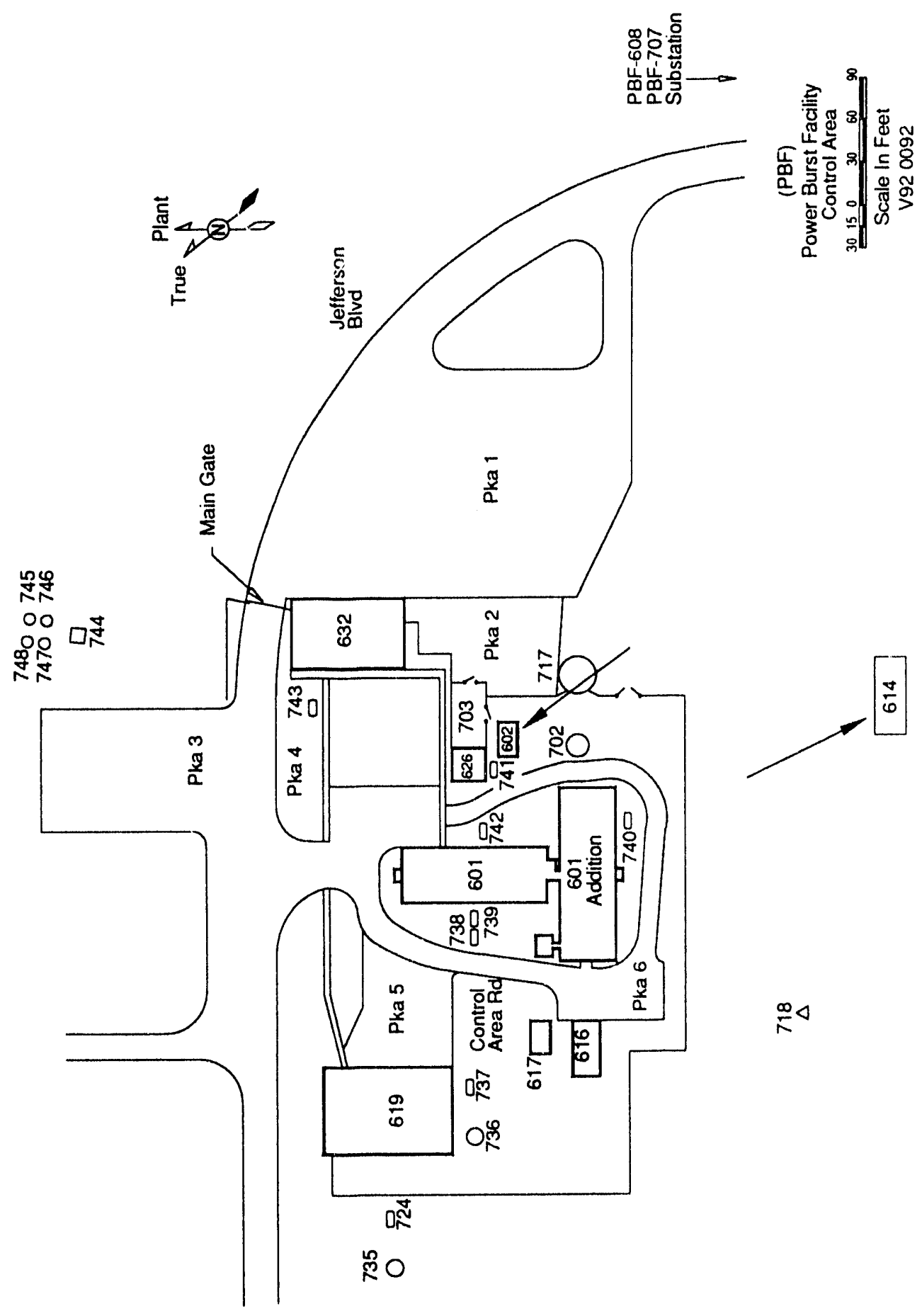

Figure 7. Plot plan of PBF showing the location of PBF-602 and the approximate location of PBF-614. 
The PBF \#1 well was completed at a depth of $653 \mathrm{ft}$ with the water level at $456 \mathrm{ft}$ and has teen in service since February 1955. This well is equipped with a 80-hp, submersible pump and is capable of pumping water at $400 \mathrm{gpm}$.

None of the parameters of concern were detected at concentrations exceeding the Federal and State MCLs. The 1992 data are consistent with previous data. The drinking water at PBF has consistently met the drinking water quality standards. The concentration of detected parameters of the 1992 drinking water analyses for the PBF \#I well are listed in Tabies 12 and 13.

\section{PBF \#2 Well}

The PBF \#2 well, located in PBF-614, is one of two wells that supply all the water to the PBF area (see Figure 7). There are approximately 120) people using the PBF water system.

The PBF \#2 well was completed at a depth of $1,217 \mathrm{ft}$ with the water level at $463 \mathrm{ft}$ and has been in service since April 1960. This well is equipped with a line-shaft pump, driven by a 200-hp motor and is capable of pumping water at $800 \mathrm{gpm}$.

Tables 12 and 13 list the parameters that were detected during 1992. No MCLs were exceeded.

\section{PBF Distribution System}

The water from both wells flows into a water storage tank, and then is distributed to all facilities located at PBF. Water samples analyzed for coliform bacteria are collected on a monthly schedule. Coliform bacteria was detected in the PBF water system for the months of June and November. After the water systems containing coliform bacteria have been flushed, the test results have been negative for coliform bacteria. An investigation was conducted to determine the source of coliform bacteria, but the actual source of contamination could not be determined. The information that was gathered through the investigation suggests that the presence of coliform bacteria is related to water line deterioration of the older water systems at the INEL and stagnant water. No other parameters analyzed exceeded the MCLs established for those parameters by the
State of Idaho and the EPA. The concentration of detected parameters for the PBF distribution system are listed in Tables 12 and 13. Table 14 lists the results of the lead and copper sampling at PBF during May and September of 1992.

\section{EBR -1 Well and Distribution System}

The EBR-I well is located in the Experimental Breeder Reactor (EBR) area (see Figure 8). The EBR-I well was completed at a depth of $1075 \mathrm{ft}$ with the water level at $596 \mathrm{ft}$ and has been in service since May 1949. This well is equipped with a 200-hp, submersible pump and is capable of pumping water at $800 \mathrm{gpm}$.

Samples collected from the EBR-I water system were collected from the wellhead and distribution system. There were no MCLs exceeded at the wellhead or distribution system. Concentrations of detected parameters for 1992 drinking water analyses of EBR-I are listed in Tables 15, 16 , and 17.

\section{Gun Range Well and Distribution System}

The Gun Range well, located in B21-607 at the Gun Range on the INEL, supplies drinking water to visitors and personnel (see Figure 9). The Gun Range well was completed at a depth of $620 \mathrm{ft}$ with the water level at $508 \mathrm{ft}$ and has been in service since January 1990. This well is equipped with a 5-hp, submersible pump and is capable of pumping water at $20 \mathrm{gpm}$.

The Gun Range water system was inactive for 1992 due to general bacteria problems detected in 1991. General bacteria is classified as a secondary drinking water standard. Secondary drinking water standards pertain to the aesthetic quality of water (i.e., odor, color, and taste). Investigations were conducted to determine the source of general bacteria. General bacteria growth that was seen in this system is believed to be the result of natural bacteria growth. Since it has not been possible to rid the system of general bacteria, a chlorination system will be installed in 1993 to correct the problem. No MCL (including coliform bacteria) was exceeded either at the wellhead and/or the distribution system for 1992 drinking water analyses. Parameters detected for 1992 at the Gun Range arc listed in Tables 18, 19, and 20. 


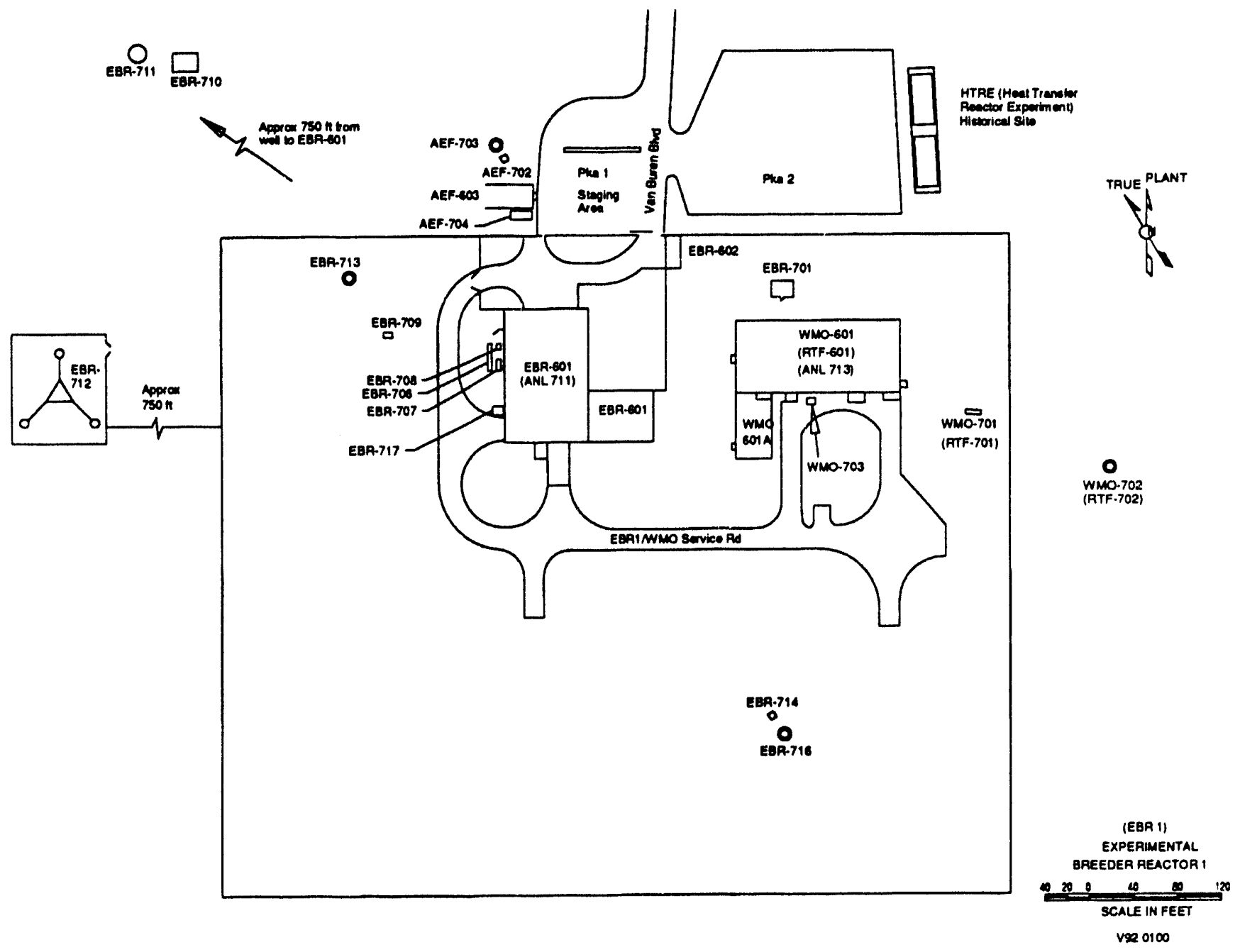

Figure 8. Plot plan of EBR-I. 


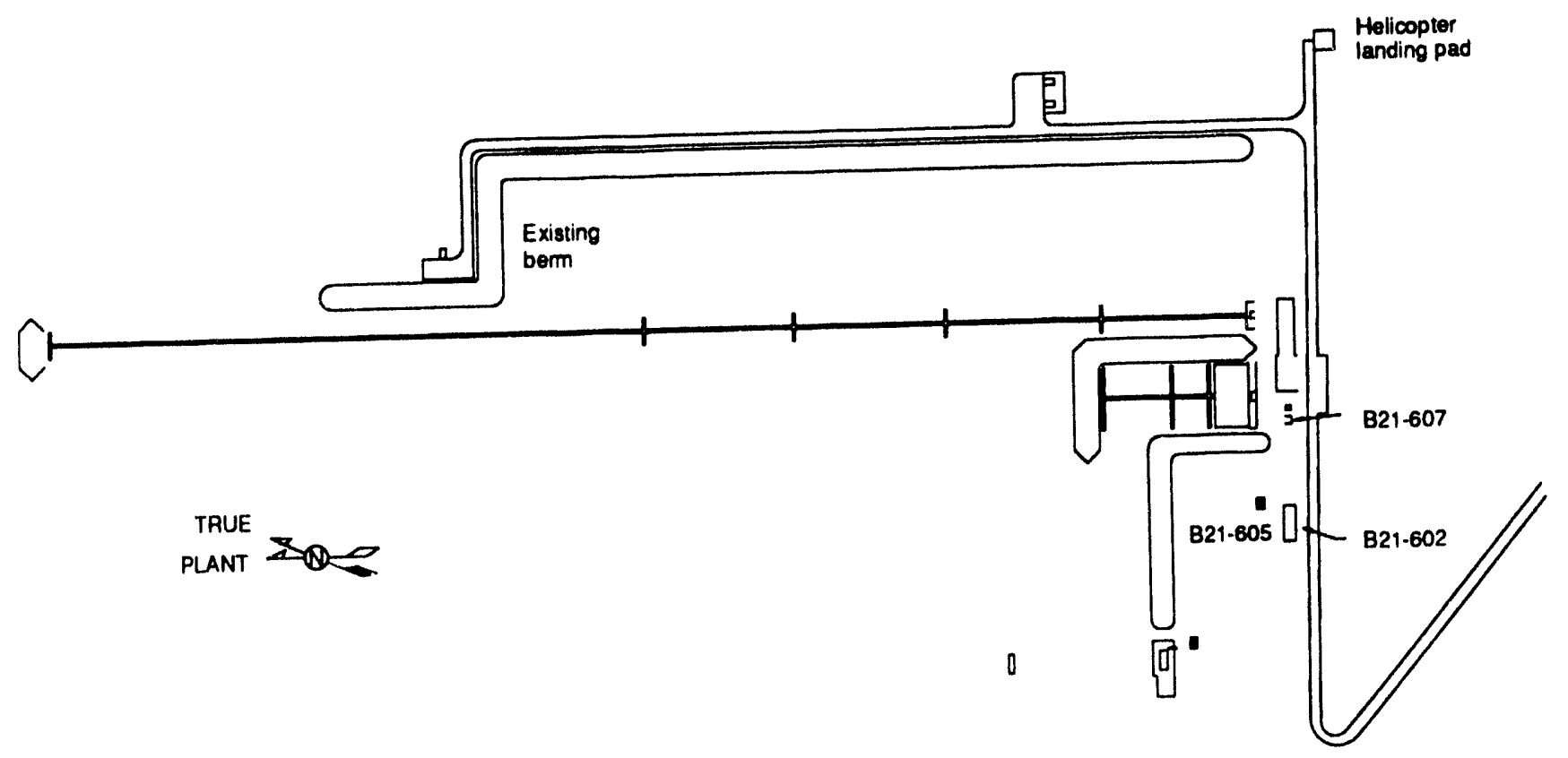

GUN RANGE

$10050 \quad 100 \quad 200 \quad 300$

SCALE IN FEET

V92 0099

Figure 9. Plot plan of the Gun Range showing the location of B21-607. 


\section{Fire Station \#2 Well and Distribution System}

The Fire Station \#2 well, is located in B16-602, approximately two miles north of ICPP on Lincoln Boulevard. A site-specific map of the Fire Station is not available. The Fire Station \#2 well was completed at a depth of $516 \mathrm{ft}$ with the water level at $420 \mathrm{ft}$ and has been in service since December 1957. This well is equipped with a line-shaft pump, driven by a 75-hp motor and is capable of pumping water at $400 \mathrm{gpm}$. This water system is inactive and does not supply drinking water to personnel and is used for ground water monitoring information purposes.

All contaminants detected for 1992 were below the MCLs established for the respective parameters. Parameters detected at the Fire Station water system during the drinking water analyses are listed in Tables 21 and 22.

\section{TRA \#1 Well}

The TRA \#1 well, located in TRA-601, is one of three wells monitored at TRA (see Figure 10). The TRA \#1 well was completed at a depth of $600 \mathrm{ft}$ with the water level at $453 \mathrm{ft}$ and has been in service since February 1950. This well is equipped with a line-shaft pump, driven by a 700-hp motor and is capable of pumping water at $3200 \mathrm{gpm}$. The TRA water supply from all wells serves approximately 539 personnel. Tables 23 and 24 list the parameters that were detected for 1992. No MCL was exceeded.

\section{TRA \#3 Well}

The TRA \#3 well, located in TRA-650, is one of three wells tested at TRA (see Figure 10). The TRA \#3 well was completed at a depth of $602 \mathrm{ft}$ with the water level at $456 \mathrm{ft}$ and has been in service since March 1957. This well is equipped with a line-shaft pump driven by a 700-hp motor and is capable of pumping water at $3800 \mathrm{gpm}$. Tables 23 and 24 list the parameters that were detected for 1992. No MCL was exceeded.

\section{TRA \#4 Well}

The TRA \#4 well, located in TRA-642, is one of three wells monitored at TRA (see Figure 10). The TRA \#4 well was completed at a depth of $965 \mathrm{ft}$ with the water level at $463 \mathrm{ft}$ and has been in service since July 1963 . This well is equipped with a line-shaft pump driven by a 350-hp motor and is capable of pumping water ac $2000 \mathrm{gpm}$. Tables 23 and 24 list the parameters that were detected for 1992. No MCL was exceeded.

\section{TRA Distribution System}

The TRA \#1, \#3, and \#4 well water is pumped into storage tanks at TRA and then is distributed as one source. TRA-608 is the point of entry where the water from the 3 wells is distributed throughout the TRA water system. This is where most of the samples are collected (except for coliform bacteria, which is done on a monthly rotating schedule for each building).

Water samples analyzed for coliform bacteria are collected routinely on a monthly schedule. Coliform bacteria was detected in the TRA water system for the months of August and December. Investigations were conducted to try to determine the source of bacteria. In August, a drinking fountain was identified as a single point source for coliform bacteria. The drinking fountain was tagged out of service and then replaced with a new one. The new drinking fountain and the TRA water system were resampled. No coliform bacteria was detected from the resampling effort. In December, stagnant water in one of the storage tanks was believed to be the source of coliform bacteria detected in the system. After flushing and chlorinating the water system and recirculating all of the water from the storage tank, the presence of coliform bacteria was not detected in the water system. Results for parameters detected at TRA are listed in Tables 23 and 24 . Table 25 lists the results of lead and copper sampling at the TRA distribution system during May and September of 1992. 


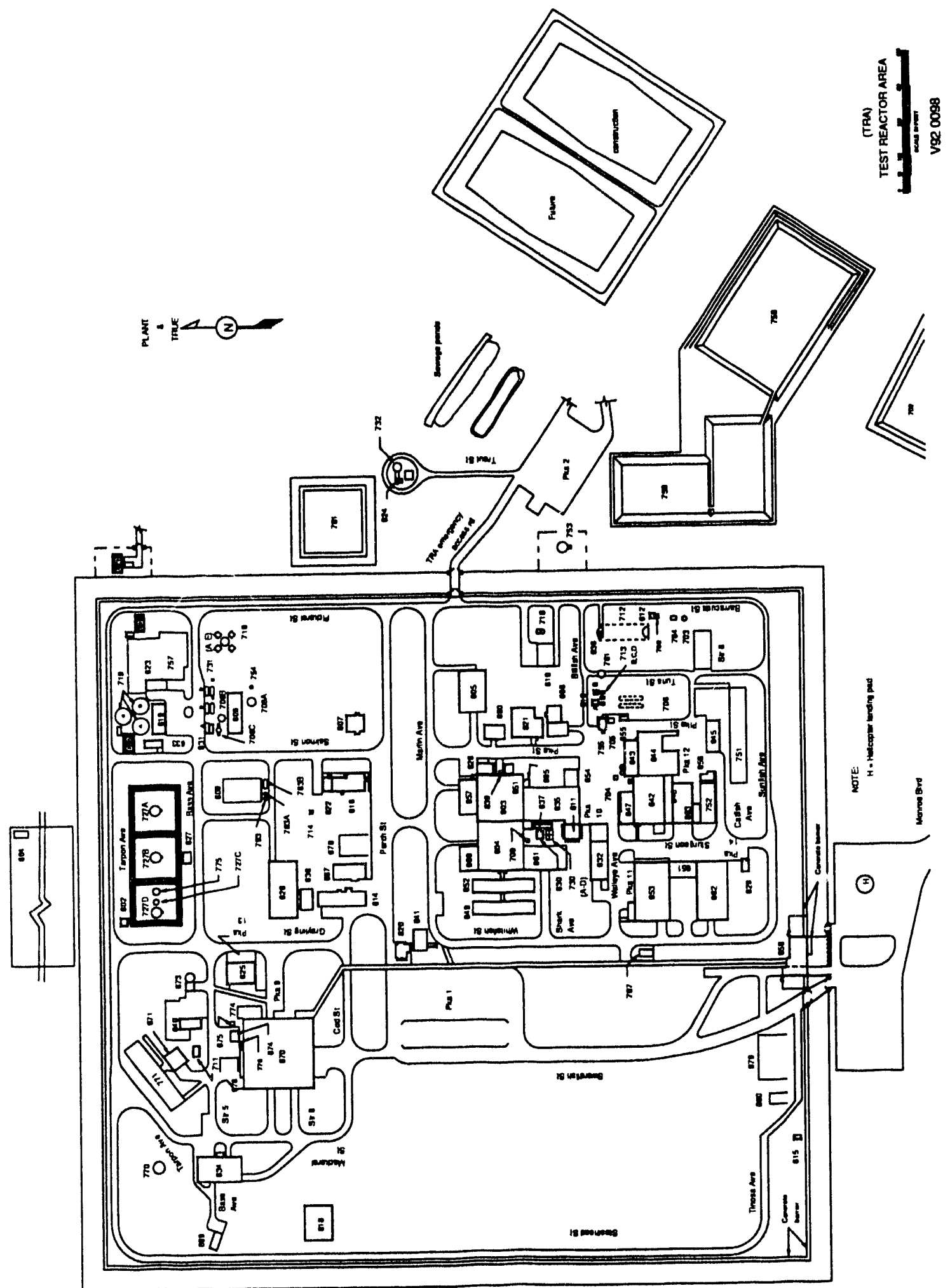

Figure 10. Plot plan of TRA showing the locations of TRA-601, -650 , and -672 . 


\section{TAN/TSF \#1 Well}

The TAN/TSF \#1 well is located in TAN-612 (see Figure 11). The TSF \#1 well was completed at a depth of $360 \mathrm{ft}$ with the water level at $208 \mathrm{ft}$ and has been in service since January 1953. This well is equipped with a line-shaft pump driven by a 80-hp motor and is capable of pumping water at $1000 \mathrm{gpm}$.

Concentrations of TCE averaged $9.1 \mu \mathrm{g} / \mathrm{L}$, which exceeds the MCL of $5.0 \mu \mathrm{g} / \mathrm{L}$. Since the installation of a sparger system (see Figure 12), which volatilizes TCE from the water, the MCL has not been exceeded at the entry point of the distribution system for water consumption. Tables 26 and 27 list the parameters detected during 1992.

The TAN injection wells are considered to be the most likely source of the TCE contamination. Figure 13 illustrates the concentrations of TCE in the two wells during 1992. The differences in concentrations of TCE between the two wells are probably related to different usage rates of the wells, proximity to the contamination source, and ground water mobility.

\section{TAN/TSF \#2 Well}

The TAN/TSF \#2 well is located in TAN-613 (see Figure 11). The TAN/TSF water system from all wells serves approximately 450 people. The TSF \#2 well was completed at a depth of $340 \mathrm{ft}$ with the water level at $211 \mathrm{ft}$ and has been in service since August 1953. This well is equipped with a line-shaft pump driven by a 80-hp motor and is capable of pumping water at $1000 \mathrm{gpm}$. Tables 26 and 27 list the parameters detected during 1992. No MCLs were exceeded. See Figure 13 for TCE concentration during 1992.

\section{TAN/TSF Distribution System}

The TAN/TSF distribution system is located in TAN-610 (see Figure 11) and is the point of entry for water entering the distribution system. In 1987, TCE was detected at both TAN/TSF $\# 1$ and \#2 wells, which supply water to the employees at TSF. In 1988, a sparger system was installed in the water storage tank reducing the TCE concentrations, providing drinking water safe for consumption. Concentrations of TCE have decreased in the distribution system since the introduction of the sparger system. The average concentration for TCE was $1.6 \mu \mathrm{g} / \mathrm{L}$ at the point of entry to the distribution system. Sampling has also been conducted at drinking fountains downstream from the sparger, to verify the effectiveness of the system at the point of consumption.

To date, the system has proven to be very effective, as Figure 13 illustrates. Monitoring will continue monthly to verify the efficiency and effectiveness of the sparger system to ensure the water remains safe for human consumption. Tables 26 and 27 list the parameters detected during 1992. Table 28 lists the results of lead and copper sampling at the TAN/TSF distribution system during May and September of 1992. Water samples analyzed for coliform bacteria are collected routinely on a monthly schedule. Coliform bacteria was detected in the TAN/TSF water system for the months of July and August. Investigations conducted were not successful in determining the actual source of coliform bacteria. The presence of coliform bacteria is believed to result from a combination of old deteriorating pipes and stagnant water build up. The work schedule for personnel at TAN is four tenhour days, Monday through Thursday. The water system is not used from Thursday night until Monday morning. Environmental Monitoring has recommended to TAN management that the water system be flushed and personnel should run water in the buildings for four to five minutes. The presence of coliform bacteria has not been detected in the water system at TAN since implementing the procedure of purging the water system. No other MCL drinking water standards were exceeded. 


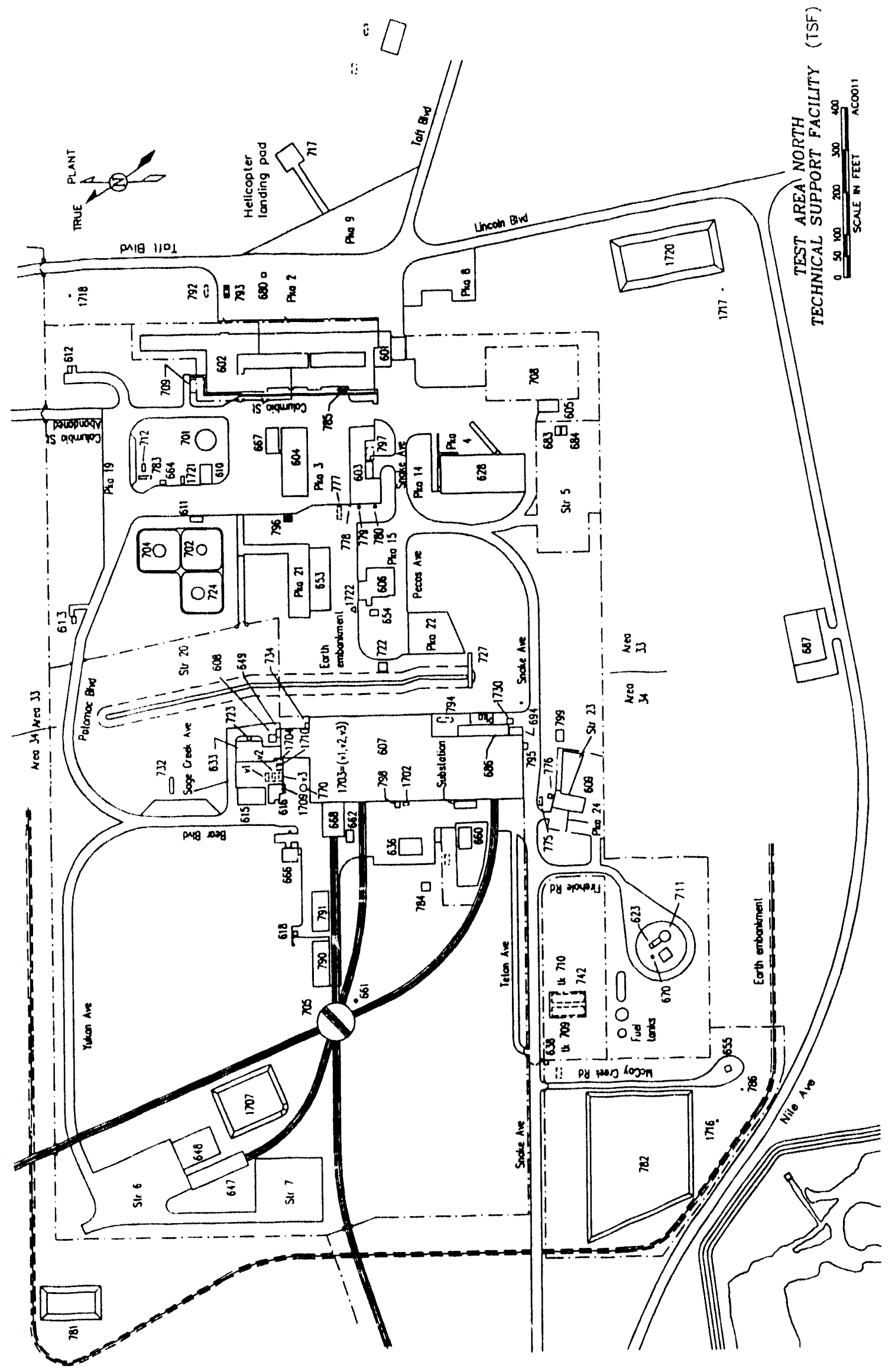

Figure 11. Plot plan of TAN/TSF showing the locations of TAN-610, -612 , and -613 . 

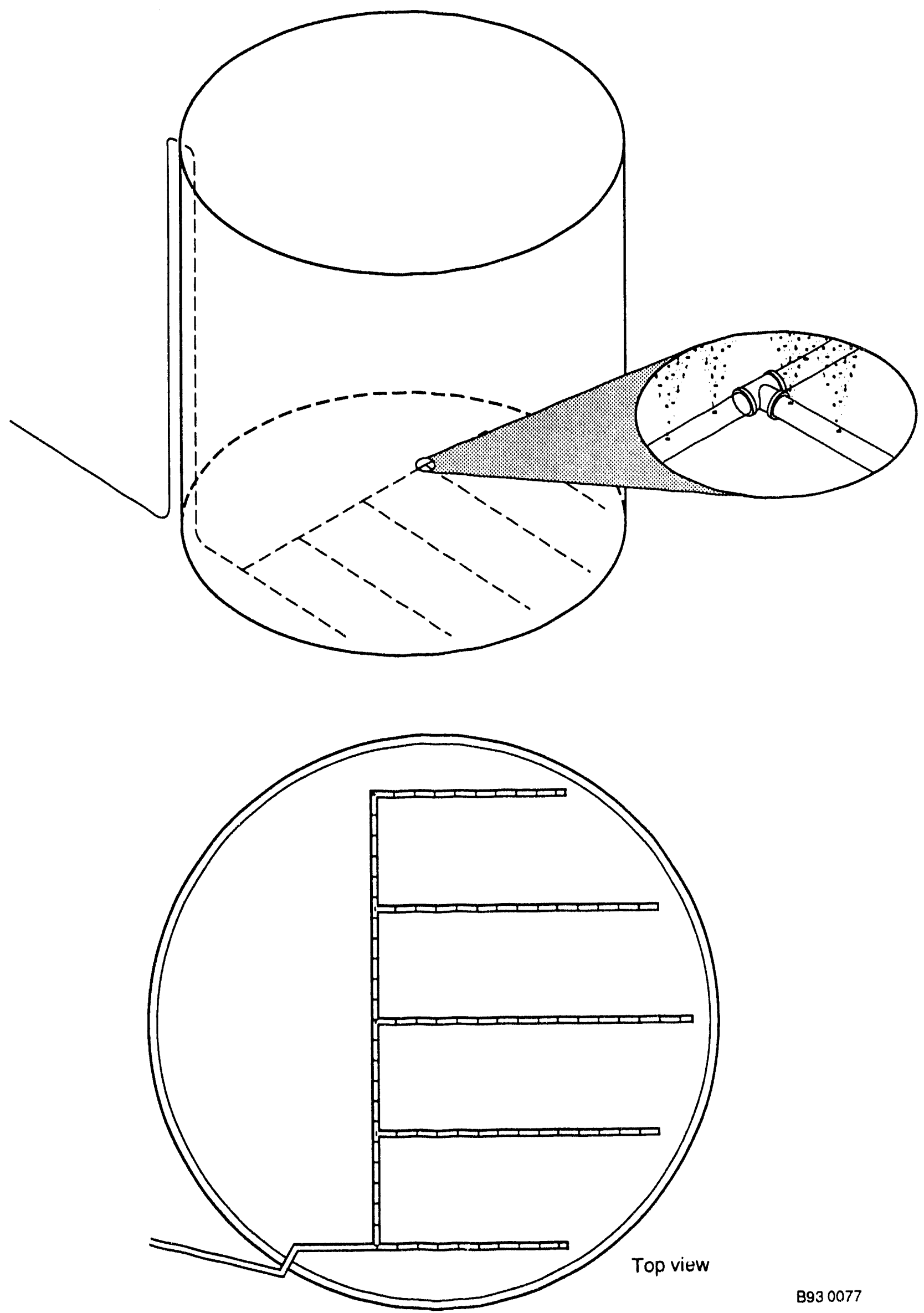

В93 0077

Figure 12. Sparger system installed in the water storage tank at TAN/TSF distribution system, TAN-610. 


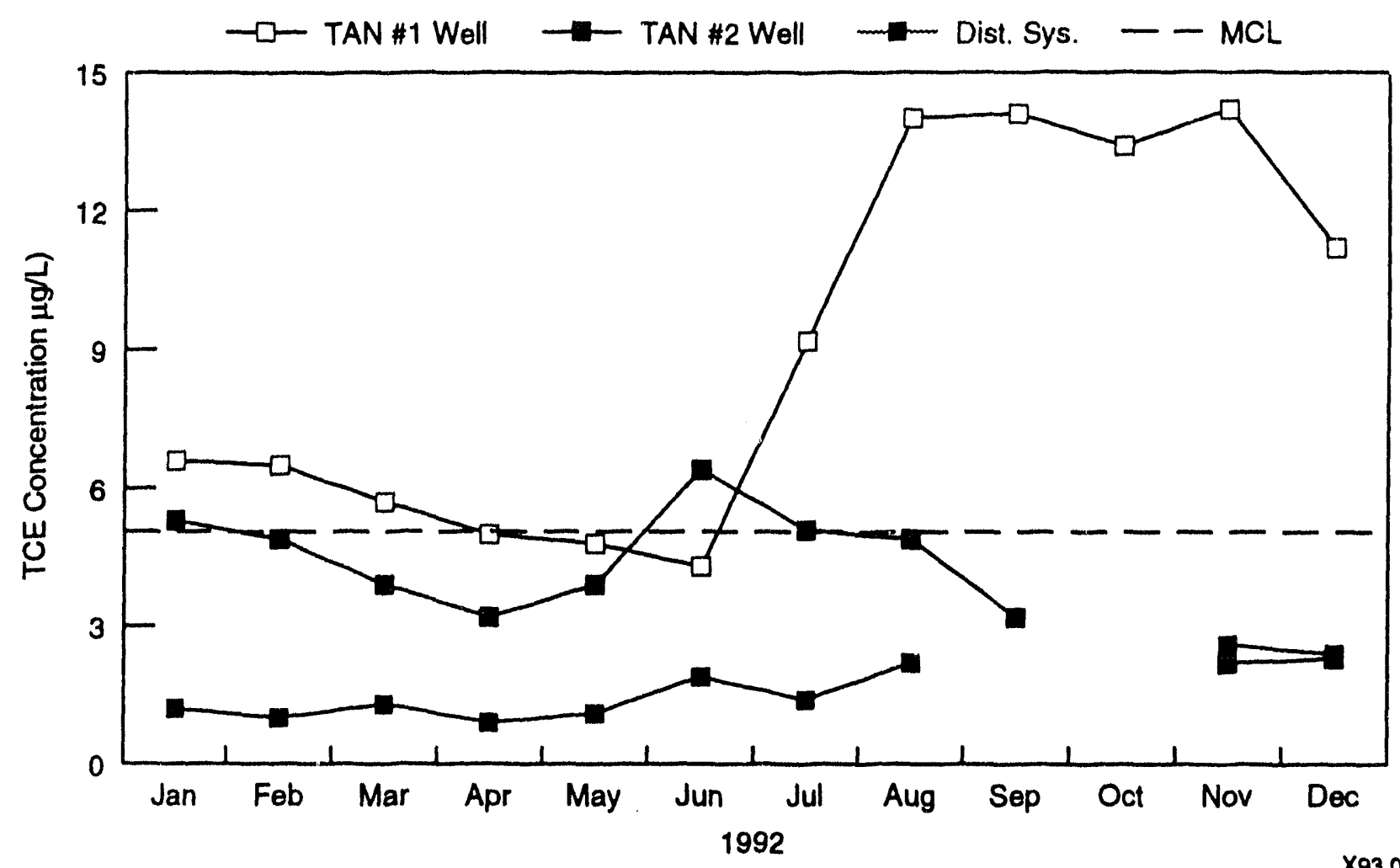

Figure 13. Monthly concentrations of TCE in TAN/TSF drinking water during 1992.

X230142

\section{TAN/CTF \#1 Well}

The TAN/CTF \#1 well is located in TAN-632 (see Figure 14). The TAN/CTF water system from all wells serves approximately 350 people. The CTF \#1 well was completed at a depth of 330 $\mathrm{ft}$ with the water level at $199 \mathrm{ft}$ and has been in service since November 1957. This well is equipped with a line-shaft pump driven by a 100-hp motor and is capable of pumping water at $1000 \mathrm{gpm}$. The detected parameters for the drinking water analyses are listed in Tables 29 and 30. No MCLs were exceeded.

\section{TAN/CTF \#2 Well}

The TAN/CTF \#2 well is located in the proximity of TAN-639 (see Figure 14). The TAN/CTF water system serves approximately 350 people. The CTF \#2 well was completed at a depth of 455 $\mathrm{ft}$ with the water level at $200 \mathrm{ft}$ and has been in service since April 1958. This well is equipped with a line-shaft pump driven by a 100-hp motor and is capable of pumping water at $1000 \mathrm{gpm}$. Tables 29 and 30 list the parameters detected during 1992. No MCLs were exceeded.

\section{TAN/CTF Distribution System}

The TAN/CTF distribution system, located in TAN-614, serves approximately 350 people each day. Water from TAN/CTF \#1 and \#2 wells is pumped into a storage tank and then is distributed throughout the system. Samples are collected from the distribution system to ensure the water is safe for consumption. Water samples analyzed for coliform bacteria are collected routinely on a monthly schedule. Coliform bacteria was detected in the TAN/CTF water system for the months of July and September. Investigations conducted determined that the source of coliform bacteria was an isolated case related to the drinking fountain. In September, stagnant water in a storage tank was believed to be the source of coliform bacteria detected in the system. Since that time, coliform bacteria has not been detected in the water system. Tables 29 and 30 list the parameters that were detected during 1992. Table 31 lists the results of lead and copper sampling at the TAN/CTF distribution system during May and September of 1992. No other MCLs were exceeded. 


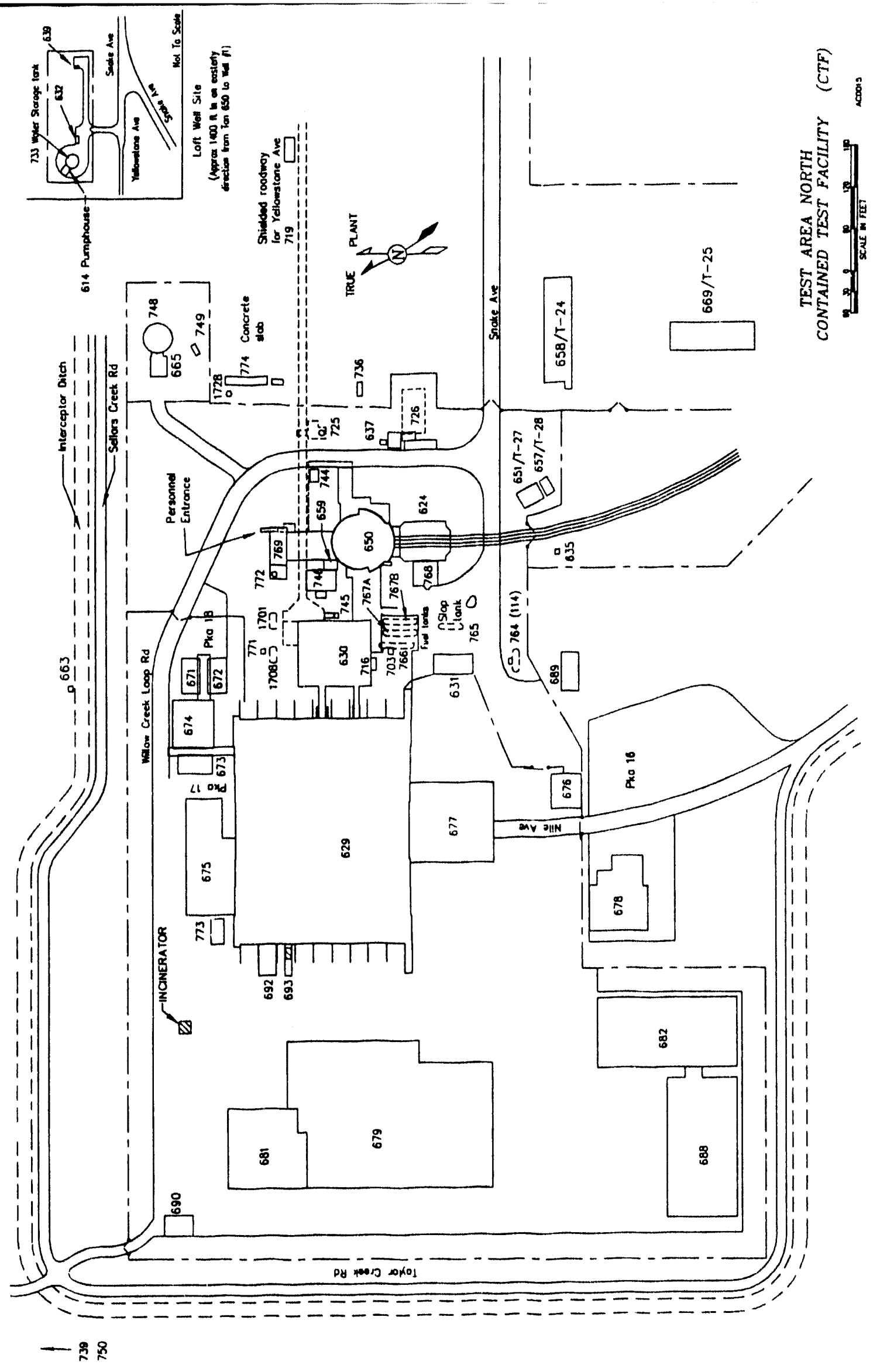

Figure 14. Plot plan of TAN/CTF showing the locations of TAN-632 and -639 (upper right hand corner). 


\section{TAN/WRRTF Well}

The TAN/WRRTF well, located near TAN-644, is inactive and does not supply drinking water to personnel (see Figure 15). The WRRTF well was completed at a depth of $309 \mathrm{ft}$ with the water level at $209 \mathrm{ft}$ and has been in service since July 1956. This well is equipped with a line-shaft pump driven by a 50-hp motor and is capable of pumping water at $4(X) \mathrm{gpm}$. The well is used for ground water information purposes.

Trichloroethylene was detected in the TAN/WRRTF distribution system at a concentration exceeding the MCL. The concentration of TCE has remained consistent each month since having been first detected in 1988. The well at TAN/WRRTF is sampled for analyses of radiological constituents for trend analyses. Water from this well is not used as a drinking water source. The drinking fountains have been taken out of service to prevent personnel from consuming the water. Personnel assigned to TAN/ WRRTF use bottled water. The bottled water consumed by the personnel at TAN/WRRTF is sampled monthly for bacteriological analyses, as is all bottled water, to ensure the quality of water that the EG\&G Idaho personnel are drinking is safe. The well has been put on inactive status by the State of Idaho, EG\&G Idaho, and DOE-ID. Detected parameters for drinking water analyses at TAN/WRRTF are listed in Tables 32 and 3.3.

\section{RWMC Well}

The RWMC well, located in WMF-603, serves 107 people (see Figure 16). The RWMC well was completed at a depth of $685 \mathrm{ft}$ with the water level at $568 \mathrm{ft}$ and has been in service since November 1974. This well is equipped with a line-shaft pump driven by a 75-hp motor and is capable of pumping water at $240 \mathrm{gpm}$. Carbon tetrachloride was discovered in this well in 1987. Monthly monitoring was conducted from 1989 to 1990. Concentrations of carbon tetrachloride remained consistent at $1.7 \mu \mathrm{g} / \mathrm{L}$ for 1992 , which is less than the $\mathrm{MCL}$ of $5.0 \mu \mathrm{g} / \mathrm{L}$. Figure 17 shows the quarterly concentrations of carbon tetrachloride in RWMC drinking water during 1992. The production well at the RWMC is being monitored for trends and VOC regulatory limits; however, at this time sampling has been reduced to quarterly sampling because detected concentrations are stable and are less than the MCL. Tables 34 and 35 list the parameters that were detected during 1992. No MCL was exceeded.

\section{RWMC Distributlon System}

The concentration of carbon tetrachloride was $0.73 \mu \mathrm{g} / \mathrm{L}$ for 1992 which is less than the MCL of $5.0 \mu \mathrm{g} / \mathrm{L}$. The results of the detected parameters for the RWMC well are listed in Tables 34,35 , and 36. 


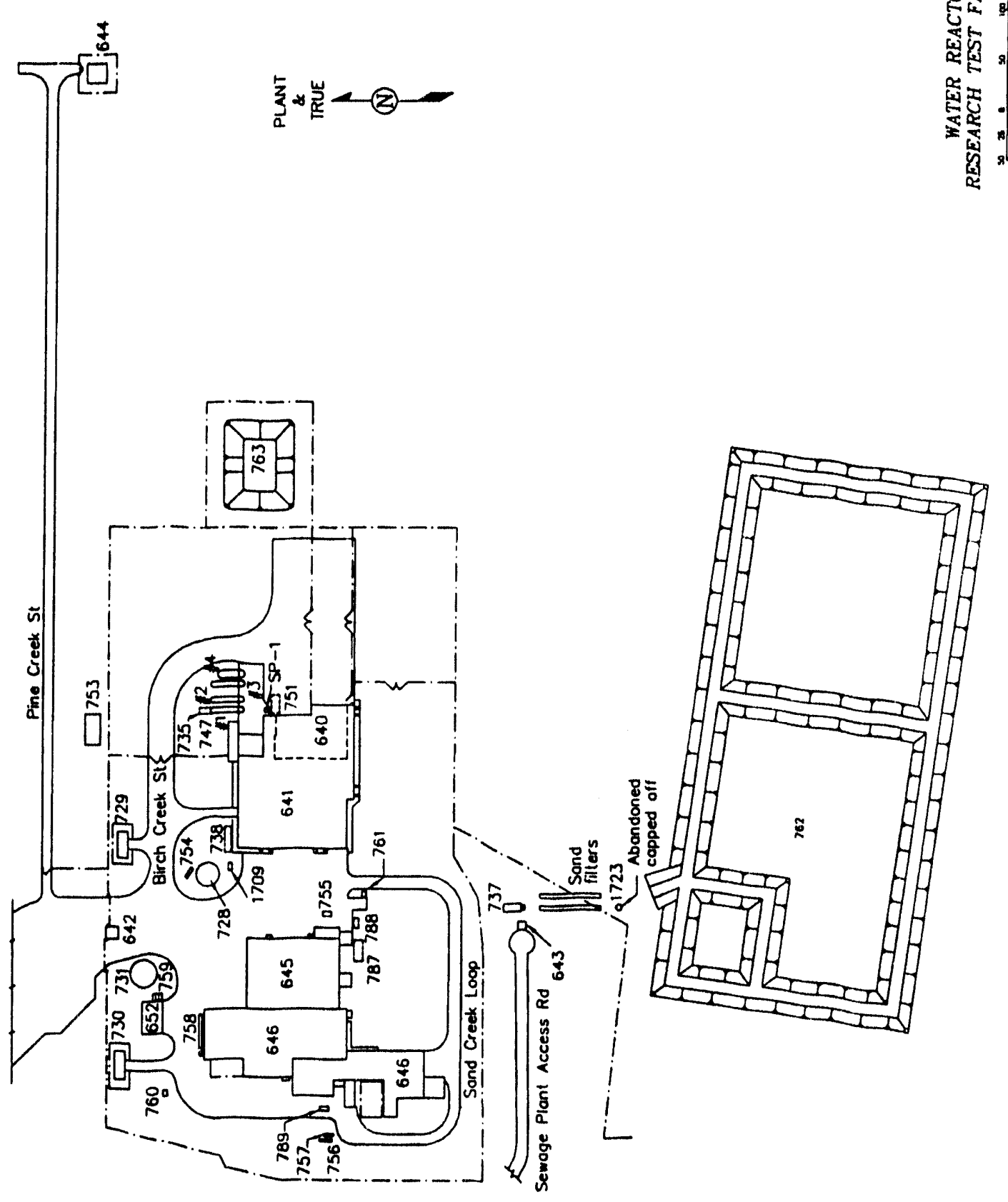

Figure 15. Plot plan of TAN/WRRTF showing the location of TAN-645. 

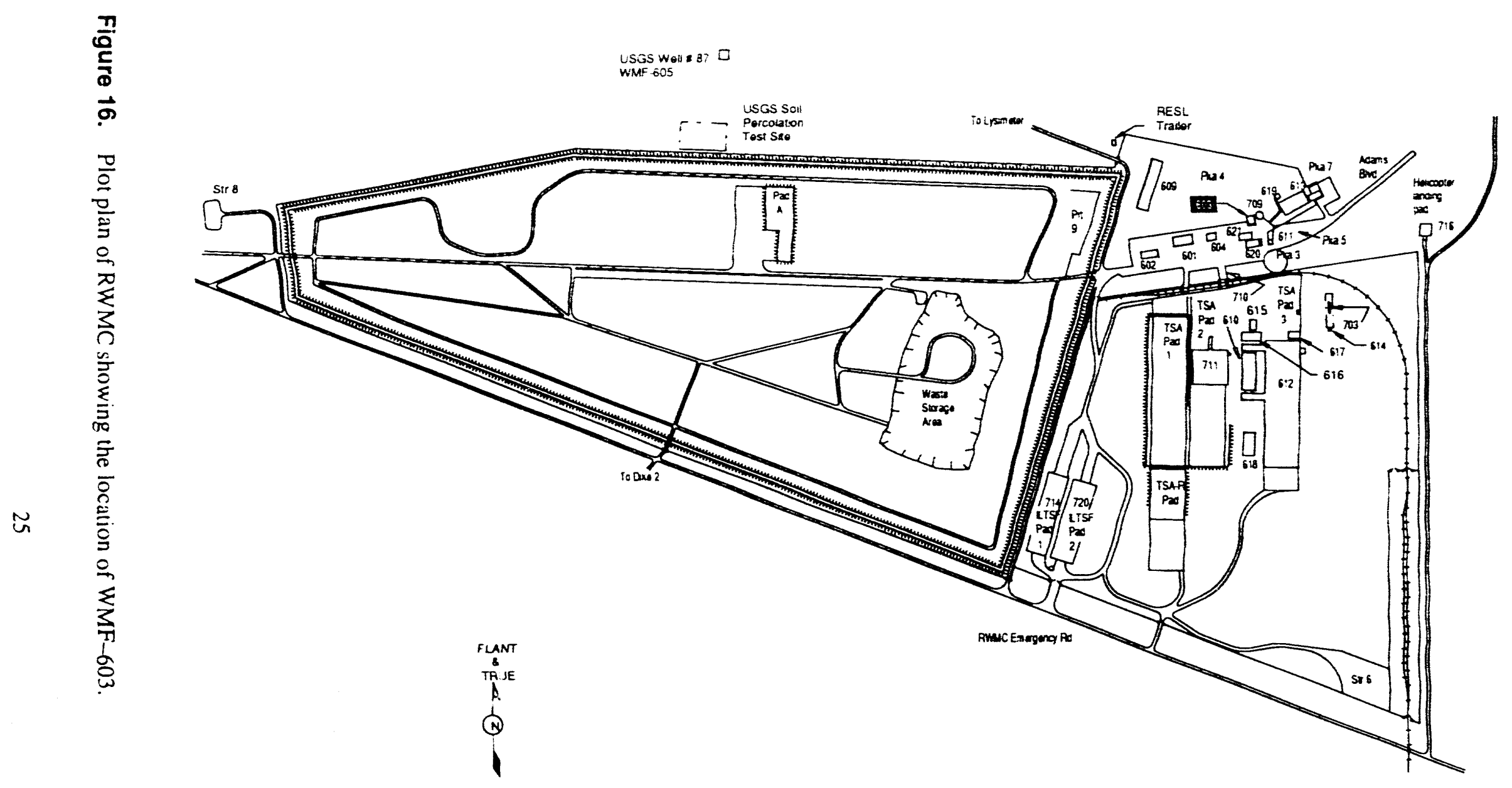
RADIOACTIVE WASTE MANAGEMENT CONPLEX $\underbrace{200000 \quad 200}_{\text {SCALE IN FEET }}$ v92 0095 


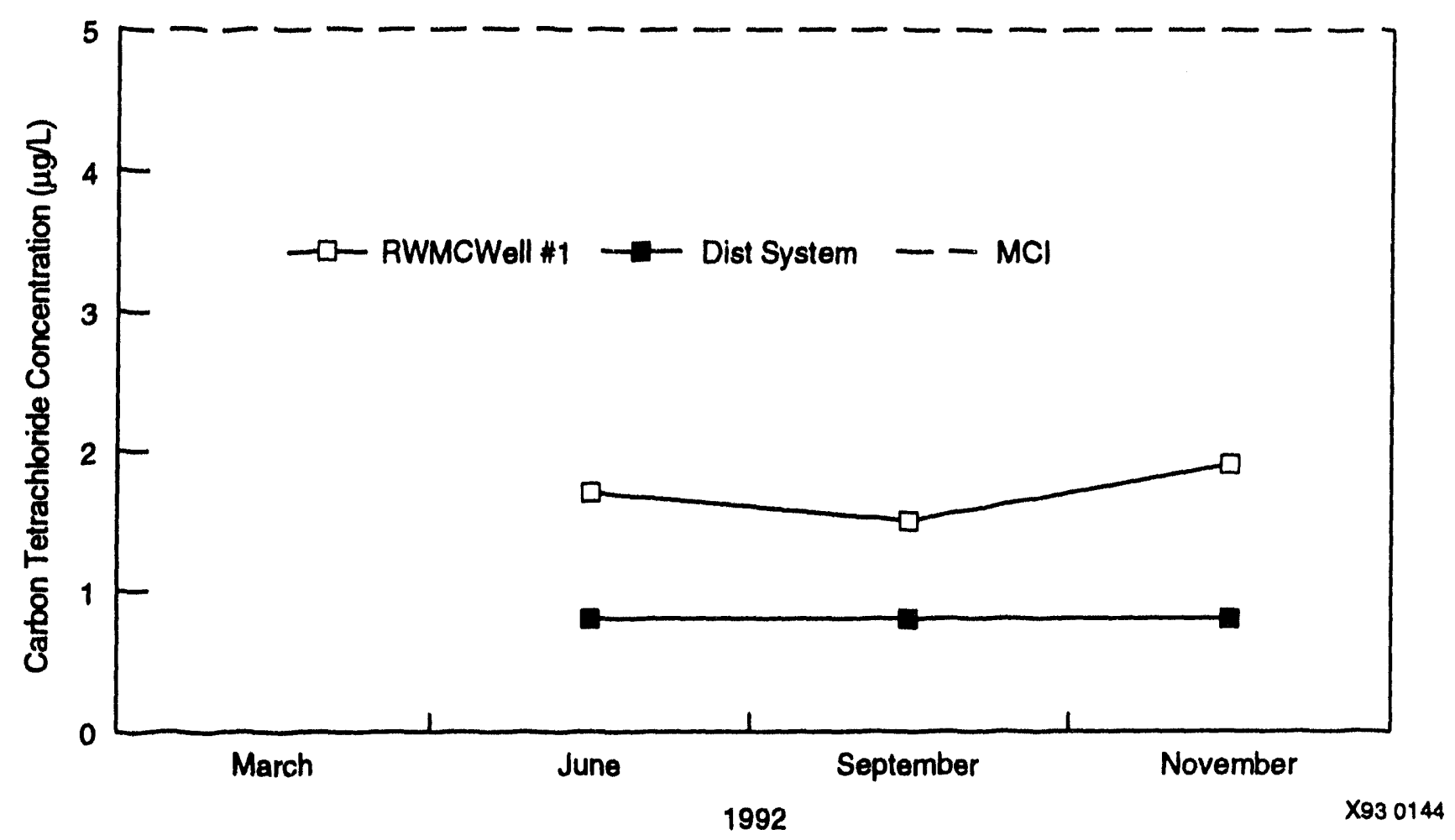

Figure 17. Monthly concentrations of carbon tetrachloride in RWMC drinking water during 1992. 
Table 1. List of parameters analyzed for calendar year 1992.

Primary drinking water parameters

Coliform Bacteria, Copper, Lead, and Organics

Coliform bacteria

Chlorthalonil

Copper

Delta-BHC

Lead

P,P' DDD

2,4-D

$\mathrm{P}, \mathrm{P}^{\prime} \mathrm{DDE}$

$2,4,5-\mathrm{T}$

$\mathrm{P}, \mathrm{P}^{\prime} \mathrm{DDT}$

2,4,5-TP (Silvex)

Dieldrin

Aldrin

Endrin Aldehyde

Alachlor

Endrin

Aldicarb Sulfoxide

Endosulfan I, II

Aldicarb

Endosulfan Sulfate

Aldicarb Sulfone

Heptachlor

Dalapon (Dowpon)

Heptachlor Epoxide

Dinoseb

Lindane

Pentachlorophenol

Methoxychlor

Pichloram

Toxaphene

Atrazine

Ethylene dibromide (EDB)

Bromacil

1,2-Dibromo-3-Chloropropane (DBCP)

Dimethoate

Thiobencarb

Molinate

3-Hydroxycarbofuran

Prometryn

Baygon

Simazine

Carbofuran (Furadan)

Chlordane

Carbaryl 
Table 1. (continued).

\section{Primary drinking water parameters}

Methiocarb

Methomyl

Oxamyl (Vydate)
PCB $1016,1221,1232,1242,1248,1254,1260$

Arochlor

Alpha-BHC

Beta-BHC
Gross Alpha

(including radium 226, excluding radon and uranium)
Gross Beta

Tritium

Regulated VOCs (Quarterly Monitoring)

Benzene

CIS-1,2-Dichloroethylene

Vinyl Chloride

1,2-Dichloropropane

Carbon Tetrachlcride

Ethylbenzene

1,2-Dichloroethane

(Mono) Chlorobenzene

Trans-1,2-Dichloroethylene
1,1,1-Trichloroethane (TCA)

0-Dichlorobenzene

para-Dichlorobenzene

Styrene

Trichloroethylene

Tetrachloroethylene (PCE)

1,1-Dichloroethylene

Toluene

Xylenes (total)

Unregulated VOCs (Quarterly Monitoring)

Chloroform $^{\mathrm{a}}$

Bromodichloromethane $\mathrm{a}^{\mathrm{a}}$

Chlorodibromomethane ${ }^{a}$
Bromoforma

m-Dichlorobenzene

Dichloromethane 
Table 1. (continued).

Primary water parameters

\section{Unregulated VOCs (Quarterly Monitoring) continued}

1,1-Dichloroethane

1,1,2,2-Tetrachloroethane

Bromobenzene

1,2,4-Trimethylbenzene

1,2,3-Trichlorobenzene

n-Butylbenzene

Dibromomethane

1,1-Dichloropropene

1,1,1,2-Tetrachloroethane

Chloroethane

1,1,2-Trichloroethane

2,2-Dichlororpropane

o-Chlorotoluene

p-Chlorotoluene

1,3-Dichloropropene

1,2,4-Trichlorobenzene
n-Propylbenzene

Napthalene

1,3-Dichloropropane

Chloromethane

Bromomethane

Hexachlorobutadiene

1,3,5-Trimethylbenzene

p-Isopropyltoluene

Isopropylbenzene

Tert-butylbenzene

Sec-butylbenzene

Fluorotrichloromethane

Dichlorodifluoromethane

Bromochloromethane

1,2,3-Trichloropropane

a. This parameter is a constituent of the total trihalomethanes. 
Table 2. Pertinent drinking water regulatory codes and orders.

Title

1. DOE 5400.5 Part Da

2. IDAPA 16.01.08000 16.01.08999b

3. 40 CFR $141-143^{C}$

4. Section 2.2.9d
Radiation Protection of the Public and the Environment

Idaho Regulations for Public Drinking Water Systems

a. DOE Order 5400.5, Part D - This DOE policy was written to provide a level of protection for people consuming drinking water at the INEL. The level of protection should be no less than the equivalence of the confidence levels listed in 40 CFR Part 141. This policy is upheld whether the INEL is operated by DOE, or through a DOE contractor such as EG\&G Idaho.

b. IDAPA 16.01.08000-.08999, Idaho regulations for Public Drinking Water Systems - The INEL drinking water must meet the standards of the Idaho regulations to be in compliance. The regulations list the parameters to be analyzed and the frequency at which the analyses should take place. The scope of the regulations is to provide a degree of assurance that public drinking water systems are protected from contamination and maintained free from contaminants that may injure the health of the consuming public.

c. 40 CFR Parts 141-143 - All states are required to comply with the Safe Drinking Water Act (SDWA) set forth by EPA, and the state regulations must be at least as stringent as the federal regulations to be in compliance. The drinking regulations for Idaho are as strict as the SDWA; therefore, the Idaho regulations have primacy.

d. DOE-ID Environmental Compliance Planning Manual, Section 2.2.9 - This section provides guidelines to the INEL contractor (EG\&G Idaho) for frequency and selection of parameters monitored in a community drinking water system. These guidelines are in accordance with the Idaho Regulations for Public Drinking Water Systems (IDAPA 16.01.08100,). 
Table 3. Parameters for EG\&G Idaho production wells and distribution systems found to be above the EPA and State of Idaho MCLs for 1992.

\begin{tabular}{|c|c|c|c|}
\hline Parameter & Location & $\begin{array}{l}\text { Results } \\
(\mathrm{mg} / \mathrm{L})\end{array}$ & $\begin{array}{l}\mathrm{MCL} \\
(\mathrm{mg} / \mathrm{L})\end{array}$ \\
\hline \multirow[t]{4}{*}{ Coliform Bacteria } & $\begin{array}{l}\text { PBF Water } \\
\text { System }\end{array}$ & $(P)^{a}$ June/Nov. & $\mathrm{pb}$ \\
\hline & $\begin{array}{l}\text { TSF Water } \\
\text { System }\end{array}$ & (P) July/August & $P$ \\
\hline & $\begin{array}{l}\text { TRA Water } \\
\text { System }\end{array}$ & (P) August/December & $\mathbf{P}$ \\
\hline & CTF Water System & (P) July/September & $\mathbf{P}$ \\
\hline Trichloroethylene $^{c}$ (TCE) & $\begin{array}{l}\text { TAN/WRRTF, Water } \\
\text { System }\end{array}$ & 0.00658 & 0.005 \\
\hline TCE & TAN/TSFd \#1, Well 612 & 0.0091 & 0.005 \\
\hline
\end{tabular}

a. Presence of coliform bacteria.

b. Coliform bacteria was detected at the following systems during 1992: PBF, TSF, TRA, and CTF water system. The detection of coliform bacteria at the CTF water system (July and September) was limited to stagnant water and an isolated case (drinking fountain). Also, at TRA (August) the coliform bacteria was limited to a drinking fountain.

At PBF (June and November), TSF (July and August), and TRA (December), the coliform bacteria was throughout the water systems. Coliform bacteria could be due to many reasons, but through investigations the main reason at the INEL is old piping (water systems), and stagnant water which causes bacteria build up.

c. At the TAN/WRRTF distribution system, located at building 645 , the trichlorethylene (TCE) was $0.00658 \mu \mathrm{g} / \mathrm{L}$ and the MCL is $0.005 \mu \mathrm{g} / \mathrm{L}$. The concentration of TCE at TAN/WRRTF, 645, has been identified since the beginning of 1988 and is consistent with previous data. At WRRTF, all drinking fountains are tagged out. Bottled water is provided for personnel at WRRTF.

d. At the TAN/TSF well \#1, located at building 612 , the TCE concentration was $0.0091 \mathrm{mg} / \mathrm{L}$ for 1992 . This concentration level is at the wellhead, which is before the sparger system which removes TCE from the water. The sparger system reduces the TCE concentration below the $\mathrm{MCL}$ of $0.005 \mathrm{mg} / \mathrm{L}$ thereby making the water safe for consumption. The actual TCE concentration at the point of entry to the distribution system for public consumption is $0.0016 \mathrm{mg} / \mathrm{L}$. 
Table 4. 1992 regulated VOCs detected and average concentrations.

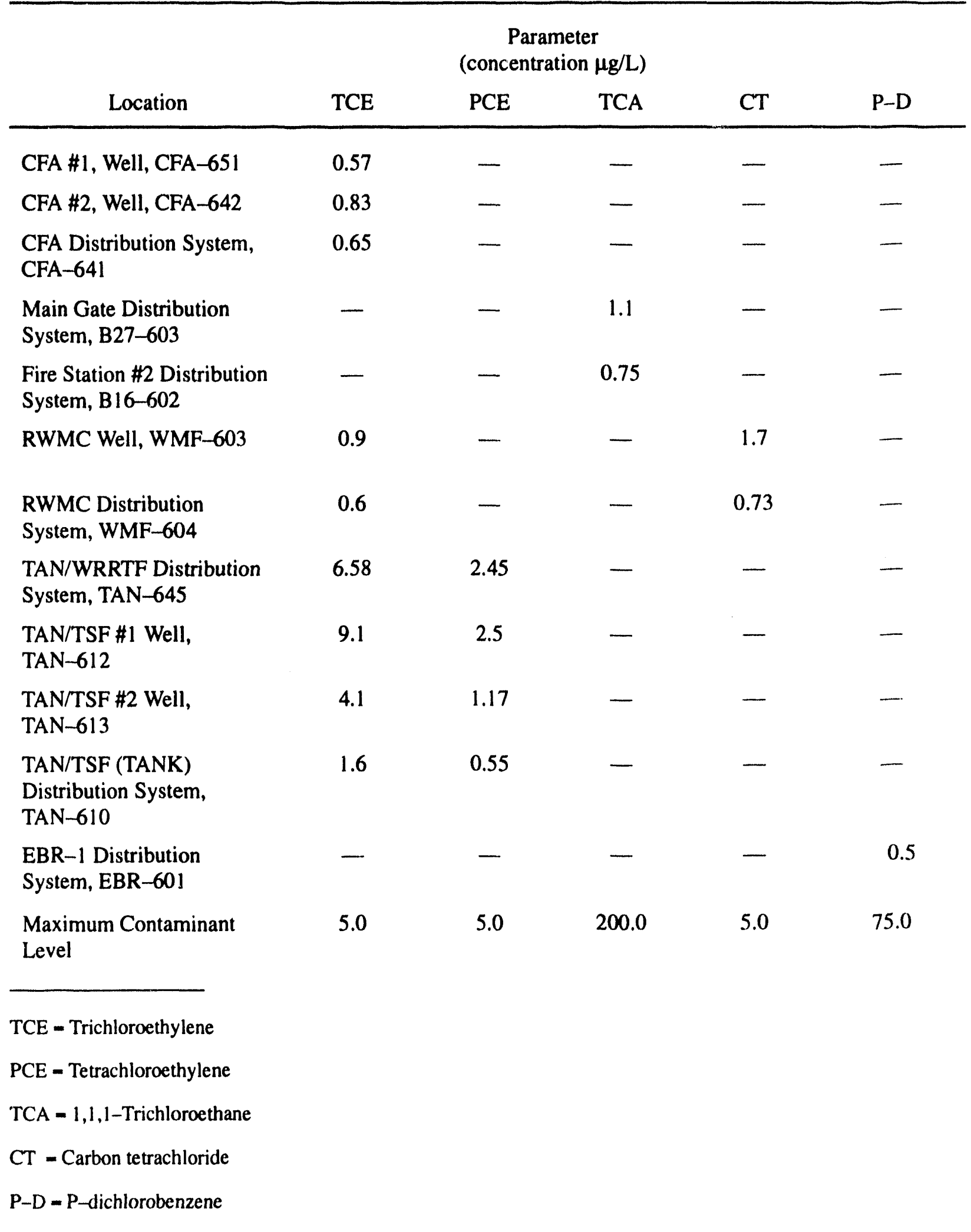

Note: Water systems at TAN/CTF, EBR-I, Gun Range, PBF, and TRA had no detection of regulated VOCs in 1992. 
Table 5. 1992 average radiological concentrations from RESL.

Parameter

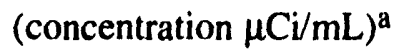

Location

Gross Alphab

Gross Betab

Tritium $^{b}$

Two quarters of sampling:

CFA (July 1, 1992 to December 30, 1992)

$7.167 \mathrm{E}-10$

$5.50 \mathrm{E}-10$

$1.647 \mathrm{E}-05$

Distribution System, CFA-641 a

Four quarters and/or monthly sampling:

CFA \#1 Well, CFA-651

CFA \#2, Well, CFA-642

Main Gate Well, B27-605

Fire Station \#2 Well, B16-602

RWMC Well, WMF-603

TAN/WRR'TF Well, TAN-645

TAN/TSF \#I Well, TAN-612

TAN/TSF \#2 Well, TAN-613

TAN/CTF Well, TAN-632

TAN/CTF Well, TAN-639

$1.25 \mathrm{E}-09$

2.108 E-09

$1.792 \mathrm{E}-05$

$9.175 \mathrm{E}-10$

$2.083 \mathrm{E}-09$

$1.602 \mathrm{E}-05$

$1.25 \mathrm{E}-09$

$1.892 \mathrm{E}-09$

$-2.083 \mathrm{E}-08$

$8.90 \mathrm{E}-10$

$6.00 \mathrm{E}-10$

-2.800 E-08

$1.65 \mathrm{E}-09$

$1.125 \mathrm{E}-09$

$1.567 \mathrm{E}-06$

$1.318 \mathrm{E}-09$

1.827 E-09

$-9.091 \mathrm{E}-10$

$1.092 \mathrm{E}-09$

$1.00 \mathrm{E}-09$

$7.417 \mathrm{E}-08$

$1.291 \mathrm{E}-09$

$1.755 \mathrm{E}-09$

$3.455 \mathrm{E}-08$

$1.275 \mathrm{E}-09$

$1.908 \mathrm{E}-09$

$-2.167 \mathrm{E}-08$

TRA \#1 Well, TRA-601

$1.117 \mathrm{E}-09$

$1.442 \mathrm{E}-09$

$-8.167 \mathrm{E}-08$

TRA \#3 Well, TRA-650

$1.245 \mathrm{E}-09$

$2.218 \mathrm{E}-09$

$-9.091 \mathrm{E}-10$

TRA \#4 Well, TRA-672

$1.370 \mathrm{E}-09$

$9.100 \mathrm{E}-10$

$7.600 \mathrm{E}-08$

TRA Distribution System, TRA-608

$1.182 \mathrm{E}-09$

$2.082 \mathrm{E}-09$

$-3.364 \mathrm{E}-08$

PBF \#1 Well, PBF-602

$1.383 \mathrm{E}-09$

$1.308 \mathrm{E}-09$

$-1.500 \mathrm{E}-08$

PBF \#2 Well, PBF-614

$1.158 \mathrm{E}-09$

$1.642 \mathrm{E}-09$

$-2.167 \mathrm{E}-08$

EBR-I Well, EBR-711

$1.233 \mathrm{E}-09$

$1.642 \mathrm{E}-09$

$-4.000 \mathrm{E}-08$

Gun Range Well, B21-607

$1.300 \mathrm{E}-09$

$7.50 \mathrm{E}-10$

$-7.083 \mathrm{E}-08$

Maximum Contaminant Level (MCL) pCi/L

$1.667 \mathrm{E}-09$

$9.500 \mathrm{E}-10$

$4.375 \mathrm{E}-06$

15

50

20,000

a. To convert $\mu \mathrm{Ci} / \mathrm{mL}$ to $\mathrm{pCi} / \mathrm{L}$, multiply the $\mu \mathrm{Ci} / \mathrm{mL}$ unit by $10^{9}$.

b. Estimated random uncertainty report is one standard deviation. 
Table 6. Results of detected radiological parameters of the drinking water analyses for samples collected at the CFA \#1 well, CFA-651; CFA \#2 well, CFA-642; and distribution system, CFA-641.

\begin{tabular}{llccc}
\hline \multicolumn{1}{c}{ Location $^{\mathrm{a}}$} & Parameter $^{\mathrm{b}}$ & $\begin{array}{c}\text { No. of months } \\
\text { monitored }\end{array}$ & $\begin{array}{c}\text { Results } \\
(\mathrm{pCi} / \mathrm{L})\end{array}$ & $\begin{array}{c}\mathrm{MCL} \\
(\mathrm{pCi} / \mathrm{L})\end{array}$ \\
\hline \multirow{2}{*}{ CFA \#1 Well } & Tritium & 12 & $19,000^{c}$ & 20,000 \\
& Gross Alpha & 12 & $1.25^{\mathrm{d}}$ & 15 \\
& Gross Beta & 12 & $2.11^{\mathrm{d}}$ & 50 \\
& Tritium & 12 & $17,920^{\mathrm{d}}$ & 20,000 \\
CFA \#2 Well & Tritium & 12 & $17,250^{\mathrm{c}}$ & 20,000 \\
& Gross Alpha & 12 & $0.917^{\mathrm{d}}$ & 15 \\
& Gross Beta & 12 & $2.09 \mathrm{~d}$ & 50 \\
CFA Distribution & Tritium & 12 & $16,020^{\mathrm{d}}$ & 20,000 \\
System & Tritium & 4 quarters & $17,750^{\mathrm{c}}$ & 20,000 \\
& Gross Alpha & 6 & $0.716^{\mathrm{d}}$ & 15 \\
& Gross Beta & 6 & 0.55 & 50 \\
& Tritium & 6 & $16,470^{\mathrm{d}}$ & 20,000
\end{tabular}

a. Wells were only sampled for VOCs and radiological constituents. The distribution system was sampled for all parameters listed in Table 1.

b. Only the parameters detected are listed.

c. Accu-Lab data: counting error-The variability of the radioactive disintegration process at the $95 \%$ confidence level is 1.960 .

d. RESL data: The estsimated random uncertainty is 1.00 .

Table 7. Results of detected nonradiological parameters of the drinking water analyses for samples collected at the CFA \#1 well, CFA-651; CFA \#2 well, CFA-642; and distribution system, CFA-641.

\begin{tabular}{|c|c|c|c|}
\hline Location $^{\text {a }}$ & Parameter ${ }^{b}$ & $\begin{array}{l}\text { Resultsc } \\
(\mathrm{mg} / \mathrm{L})\end{array}$ & $\begin{array}{l}\mathrm{MCL} \\
(\mathrm{mg} / \mathrm{L})\end{array}$ \\
\hline CFA \#I Well & Trichloroethylene & 0.00057 & 0.005 \\
\hline CFA \#2 Well & Trichloroethylene & 0.00083 & 0.005 \\
\hline $\begin{array}{l}\text { CFA Distribution } \\
\text { System }\end{array}$ & $\begin{array}{l}\text { Trichloroethylene } \\
\text { TTHM }\end{array}$ & $\begin{array}{l}0.00065 \\
0.0046\end{array}$ & $\begin{array}{l}0.005 \\
0.10\end{array}$ \\
\hline \multicolumn{4}{|c|}{$\begin{array}{l}\text { a. Wells were only sampled for VOCs and radiological constituents. The distribution system was sampled for all parameters liste } \\
\text { in Table } 1 .\end{array}$} \\
\hline \multicolumn{4}{|c|}{ b. Only the parameters detected are listed. } \\
\hline c. Four quarters & & & \\
\hline
\end{tabular}


Table 8. Results of the lead and copper sampling at CFA during May and September of 1992.

\begin{tabular}{|c|c|c|c|c|}
\hline Location & Parameter & $\begin{array}{l}\text { May Results } \\
(\mathrm{mg} / \mathrm{L})\end{array}$ & $\begin{array}{l}\text { Sept. Results } \\
(\mathrm{mg} / \mathrm{L})\end{array}$ & $\begin{array}{c}\mathrm{MCL} \\
(\mathrm{mg} / \mathrm{L})\end{array}$ \\
\hline \multirow[t]{4}{*}{ CFA-674 } & Lead & 0.0028 & 0.0021 & 0.015 \\
\hline & Copper & 0.0047 & 0.0093 & 1.3 \\
\hline & Lead & 0.0077 & 0.0028 & 0.015 \\
\hline & Copper & 0.0093 & 0.012 & 1.3 \\
\hline \multirow{2}{*}{ CFA-663 } & Lead & 0.0063 & 0.0043 & 0.015 \\
\hline & Copper & 0.280 & 0.350 & 1.3 \\
\hline \multirow[t]{4}{*}{ CFA-602 } & Lead & 0.0022 & 0.0008 & 0.015 \\
\hline & Copper & 0.012 & 0.003 & 1.3 \\
\hline & Lead & 0.0035 & 0.0006 & 0.015 \\
\hline & Copper & 0.011 & 0.0045 & 1.3 \\
\hline \multirow[t]{6}{*}{ CFA-607 } & Lead & 0.0045 & 0.0007 & 0.015 \\
\hline & Copper & 0.0048 & 0.0059 & 1.3 \\
\hline & Lead & 0.013 & 0.005 & 0.015 \\
\hline & Copper & 0.041 & 0.0055 & 1.3 \\
\hline & Lead & - & 0.0012 & 0.015 \\
\hline & Copper & - & 0.0066 & 1.3 \\
\hline \multirow[t]{4}{*}{ CFA-674 } & Lead & - & 0.0063 & 0.015 \\
\hline & Copper & - & 0.009 & 1.3 \\
\hline & Lead & - & 0.005 & 0.015 \\
\hline & Copper & - & 0.018 & 1.3 \\
\hline \multirow[t]{6}{*}{ CFA-606 } & Lead & 0.0013 & 0.001 & 0.015 \\
\hline & Copper & 0.0037 & 0.0089 & 1.3 \\
\hline & Lead & 0.0047 & 0.0017 & 0.015 \\
\hline & Copper & 0.014 & 0.0044 & 1.3 \\
\hline & Lead & 0.011 & 0.0 & 0.015 \\
\hline & Copper & 0.010 & 0.0048 & 1.3 \\
\hline \multirow[t]{4}{*}{ CFA-681 } & Lead & 0.0048 & 0.002 & 0.015 \\
\hline & Copper & 0.100 & 0.046 & 1.3 \\
\hline & Lead & - & 0.0015 & 0.015 \\
\hline & Copper & - & 0.058 & 1.3 \\
\hline \multirow[t]{2}{*}{ CFA-643 } & Lead & 0.0014 & 0.0 & 0.015 \\
\hline & Copper & 0.026 & 0.032 & 1.3 \\
\hline CFA-615 & Lead & 0.0024 & 0.0016 & 0.015 \\
\hline
\end{tabular}


Table 8. (continued).

\begin{tabular}{lllll}
\hline Location & Parameter & $\begin{array}{c}\text { May Results } \\
(\mathrm{mg} / \mathrm{L})\end{array}$ & $\begin{array}{c}\text { Sept. Results } \\
(\mathrm{mg} / \mathrm{L})\end{array}$ & $\begin{array}{c}\text { MCL } \\
(\mathrm{mg} / \mathrm{L})\end{array}$ \\
\hline & Copper & 0.390 & 0.390 & 1.3 \\
& Lead & 0.0043 & 0.0011 & 0.015 \\
& Copper & 0.580 & 0.340 & 1.3 \\
& Lead & 0.0053 & 0.0013 & 0.015 \\
CFA-614 & Copper & 0.440 & 0.320 & 1.3 \\
& Lead & 0.0045 & - & 0.015 \\
CFA-612 & Copper & 0.200 & - & 1.3 \\
& Lead & 0.0035 & - & 0.015 \\
CFA-663 & Copper & 0.017 & - & 1.3 \\
& Lead & 0.0084 & - & 0.015 \\
& Copper & 0.380 & - & 1.3 \\
CFA-652 & Lead & 0.0019 & 0.015 \\
& Copper & 0.023 & 1.3 \\
\hline
\end{tabular}

Table 9. Results of detected radiological parameters of the 1992 drinking water analyses for Main Gate well, B27-605.

\begin{tabular}{llccc}
\hline \multicolumn{1}{c}{ Location $^{\mathrm{a}}$} & Parameter & $\begin{array}{c}\text { No. of months } \\
\text { monitored }\end{array}$ & $\begin{array}{c}\text { Results } \\
(\mathrm{pCi} / \mathrm{L})\end{array}$ & $\begin{array}{c}\text { MCL } \\
(\mathrm{pCi} / \mathrm{L})\end{array}$ \\
\hline Main Gate Well & $\begin{array}{l}\text { Gross Alpha } \\
\text { Gross Beta }\end{array}$ & 12 & 1.25 & 15 \\
& Tritium & 12 & 1.89 & 50 \\
& & & 20,000 \\
a. The Main Gate well was sampled only for the radiological parameters listed in Table 1. & \\
b. RESL data: The estsimated random uncertainty is 1.00. & & \\
\hline
\end{tabular}


Table 10. Results of detected nonradiological parameters of the 1992 drinking water analyses for Main Gate distribution system, B27-603.

\begin{tabular}{|c|c|c|c|}
\hline Location $^{\mathrm{a}}$ & Parameter ${ }^{b}$ & $\begin{array}{l}\text { Results }^{c} \\
(\mathrm{mg} / \mathrm{L})\end{array}$ & $\begin{array}{l}\mathrm{MCL} \\
(\mathrm{mg} / \mathrm{L})\end{array}$ \\
\hline $\begin{array}{l}\text { Main Gate } \\
\text { Distribution } \\
\text { System }\end{array}$ & 1,1,1-Trichloroethane & 0.0011 & 0.200 \\
\hline \multicolumn{4}{|c|}{$\begin{array}{l}\text { a. The Main Gate distribution system was sampled for all parameters listed in Table 1, except for the radiological } \\
\text { parameters. }\end{array}$} \\
\hline \multicolumn{4}{|c|}{ b. Only the parameters detected are listed. } \\
\hline
\end{tabular}

Table 11. Results of the lead and copper sampling at the Main Gate during May and September of 1992.

\begin{tabular}{lllll}
\hline \multicolumn{1}{c}{ Location } & Parameter & $\begin{array}{c}\text { May Results } \\
(\mathrm{mg} / \mathrm{L})\end{array}$ & $\begin{array}{c}\text { Sept. Results } \\
(\mathrm{mg} / \mathrm{L})\end{array}$ & $\begin{array}{c}\text { MCL } \\
(\mathrm{mg} / \mathrm{L})\end{array}$ \\
\hline $\begin{array}{l}\text { Main Gate } \\
\text { Distribution }\end{array}$ & Lead & 0.0035 & 0.0058 & 0.015 \\
System & Copper & 0.170 & 0.083 & 1.3 \\
& Lead & 0.0032 & 0.0049 & 0.015 \\
& Copper & 0.170 & 0.027 & 1.3 \\
& Lead & 0.0048 & 0.0018 & 0.015 \\
& Copper & 0.026 & 0.025 & 1.3 \\
& Lead & 0.0054 & 0.0019 & 0.015 \\
& Copper & 0.080 & 0.150 & 1.3 \\
& Lead & 0.0053 & 0.012 & 0.015 \\
& Copper & 0.049 & 0.140 & 1.3 \\
\hline
\end{tabular}


Table 12. Results of detected radiological parameters of the drinking water analyses for PBF \#I well, PBF-602; PBF \#2 well, PBF-614.

\begin{tabular}{|c|c|c|c|c|}
\hline Location $^{a}$ & Parameter & $\begin{array}{c}\text { No. of months } \\
\text { monitored }\end{array}$ & $\begin{array}{l}\text { Results }^{b} \\
(\mathrm{pCi} / \mathrm{L})\end{array}$ & $\begin{array}{c}\mathrm{MCL} \\
(\mathrm{pCi} / \mathrm{L})\end{array}$ \\
\hline \multirow[t]{3}{*}{ PBF \#1 Well } & Gross Alpha & 12 & 1.158 & 15 \\
\hline & Gross Beta & 12 & 1.642 & 50 \\
\hline & Tritium & 12 & $<0$ & 20,000 \\
\hline \multirow[t]{3}{*}{ PBF \#2 Well } & Gross Alpha & 12 & 1.233 & 15 \\
\hline & Gross Beta & 12 & 1.642 & 50 \\
\hline & Tritium & 12 & $<0$ & 20,000 \\
\hline
\end{tabular}

Table 13. Results of detected nonradiological parameters of the drinking water analyses for PBF distribution system, PBF-602.

\begin{tabular}{lccc}
\multicolumn{1}{c}{ Location $^{\mathrm{a}}$} & Parameter $^{\mathrm{b}}$ & Results & MCL \\
\hline $\begin{array}{l}\text { PBF Distribution } \\
\text { System }\end{array}$ & Coliform Bacteria & $\mathrm{pc}$ & $\mathrm{P}$
\end{tabular}

\footnotetext{
a. The distribution system was sampled for all parameters listed in Table 1, except for the radiological parameters.

b. Only the parameters detected are listed.

c. P - Presence for coliform bacteria only for June and November.
} 
Table 14. Results of the lead and copper sampling at PBF during May and September of 1992.

\begin{tabular}{|c|c|c|c|c|}
\hline Location & Parameter & $\begin{array}{c}\text { May Results } \\
(\mathrm{mg} / \mathrm{L})\end{array}$ & $\begin{array}{l}\text { Sept. Results } \\
(\mathrm{mg} / \mathrm{L})\end{array}$ & $\begin{array}{c}\mathrm{MCL} \\
(\mathrm{mg} / \mathrm{L})\end{array}$ \\
\hline \multirow[t]{6}{*}{ PBF-612 } & Lead & 0.0016 & 0.0 & 0.015 \\
\hline & Copper & 0.0044 & 0.0027 & 1.3 \\
\hline & Lead & 0.012 & 0.0011 & 0.015 \\
\hline & Copper & 0.016 & 0.0019 & 1.3 \\
\hline & Lead & 0.0014 & 0.0019 & 0.015 \\
\hline & Copper & 0.0021 & 0.0021 & 1.3 \\
\hline \multirow[t]{8}{*}{ PBF-601 } & Lead & 0.0012 & 0.0021 & 0.015 \\
\hline & Copper & 0.051 & 0.049 & 1.3 \\
\hline & Lead & 0.0013 & - & 0.015 \\
\hline & Copper & 0.013 & - & 1.3 \\
\hline & Lead & 0.011 & 0.002 & 0.015 \\
\hline & Copper & 0.340 & 0.013 & 1.3 \\
\hline & Lead & 0.0024 & 0.0082 & 0.015 \\
\hline & Copper & 0.030 & 0.051 & 1.3 \\
\hline \multirow[t]{8}{*}{ PBF-632 } & Lead & 0.0012 & 0.0 & 0.015 \\
\hline & Copper & 0.0041 & 0.0064 & 1.3 \\
\hline & Lead & 0.0027 & 0.0011 & 0.015 \\
\hline & Copper & 0.0061 & 0.0042 & 1.3 \\
\hline & Lead & 0.0011 & - & 0.015 \\
\hline & Copper & 0.0053 & 0.003 & 1.3 \\
\hline & Lead & - & 0.0014 & 0.015 \\
\hline & Copper & - & 0.0045 & 1.3 \\
\hline
\end{tabular}


Table 15. Results of detected radiological parameters of the drinking water analyses for EBR-I well, EBR-711.

\begin{tabular}{llccc}
\hline Location & Parameter & $\begin{array}{c}\text { No. of months } \\
\text { monitored }\end{array}$ & $\begin{array}{c}\text { Results }^{\mathrm{b}} \\
(\mathrm{pCi} / \mathrm{L})\end{array}$ & $\begin{array}{c}\text { MCL } \\
(\mathrm{pCi} / \mathrm{L})\end{array}$ \\
\hline \multirow{2}{*}{ EBR-I Well } & Gross Alpha & 12 & 1.3 & 15 \\
& Gross Beta & 12 & 0.75 & 50 \\
& Tritium & 12 & $<0$ & 20,000
\end{tabular}

a. The EBR-I well was sampled only for the radiological parameters listed in Table 1.

b. RESL data: The estimated random uncertainty is 1.00 .

Table 16. Results of detected nonradiological parameters of the drinking water analyses for EBR-I distribution system, EBR-601.

\begin{tabular}{lll}
\hline \multicolumn{1}{c}{ Lacation $^{\mathrm{a}}$} & $\begin{array}{l}\text { Results } \\
(\mathrm{mg} / \mathrm{L})\end{array}$ & $\begin{array}{l}\text { MCL } \\
(\mathrm{mg} / \mathrm{L})\end{array}$ \\
\hline $\begin{array}{l}\text { EBR-I } \\
\text { Distribution } \\
\text { System }\end{array}$ & $0.0005^{\mathrm{c}}$ & 0.075 \\
\hline $\begin{array}{l}\text { Para-Dichlorobenzene } \\
\text { ters. }\end{array}$ & \\
b. Only the parameters detected are listed. \\
c. Detected only once in 4 quarters of monitoring.
\end{tabular}


Table 17. Results of the lead and copper sampling at EBR-I during May and September of 1992.

\begin{tabular}{lllll}
\hline \multicolumn{1}{c}{ Location } & Parameter & $\begin{array}{c}\text { May Results } \\
(\mathrm{mg} / \mathrm{L})\end{array}$ & $\begin{array}{c}\text { Sept. Results } \\
(\mathrm{mg} / \mathrm{L})\end{array}$ & $\begin{array}{c}\text { MCL } \\
(\mathrm{mg} / \mathrm{L})\end{array}$ \\
\hline $\begin{array}{llll}\text { EBR-1 } \\
\text { Distribution }\end{array}$ & Lead & 0.0078 & 0.0047 & 0.015 \\
System & Copper & 0.017 & 0.067 & 1.3 \\
& Lead & 0.0055 & 0.012 & 0.015 \\
& Copper & 0.022 & 0.100 & 1.3 \\
& Lead & 0.0031 & 0.0018 & 0.015 \\
& Copper & 0.012 & 0.007 & 1.3 \\
& Lead & 0.005 & 0.0048 & 0.015 \\
& Copper & 0.075 & 0.015 & 1.3 \\
& Lead & 0.0026 & 0.0035 & 0.015 \\
& Copper & 0.0072 & 0.016 & 1.3 \\
\hline
\end{tabular}

Table 18. Results of detected radiological parameters of the drinking water analyses for Gun Range well, B21-607.

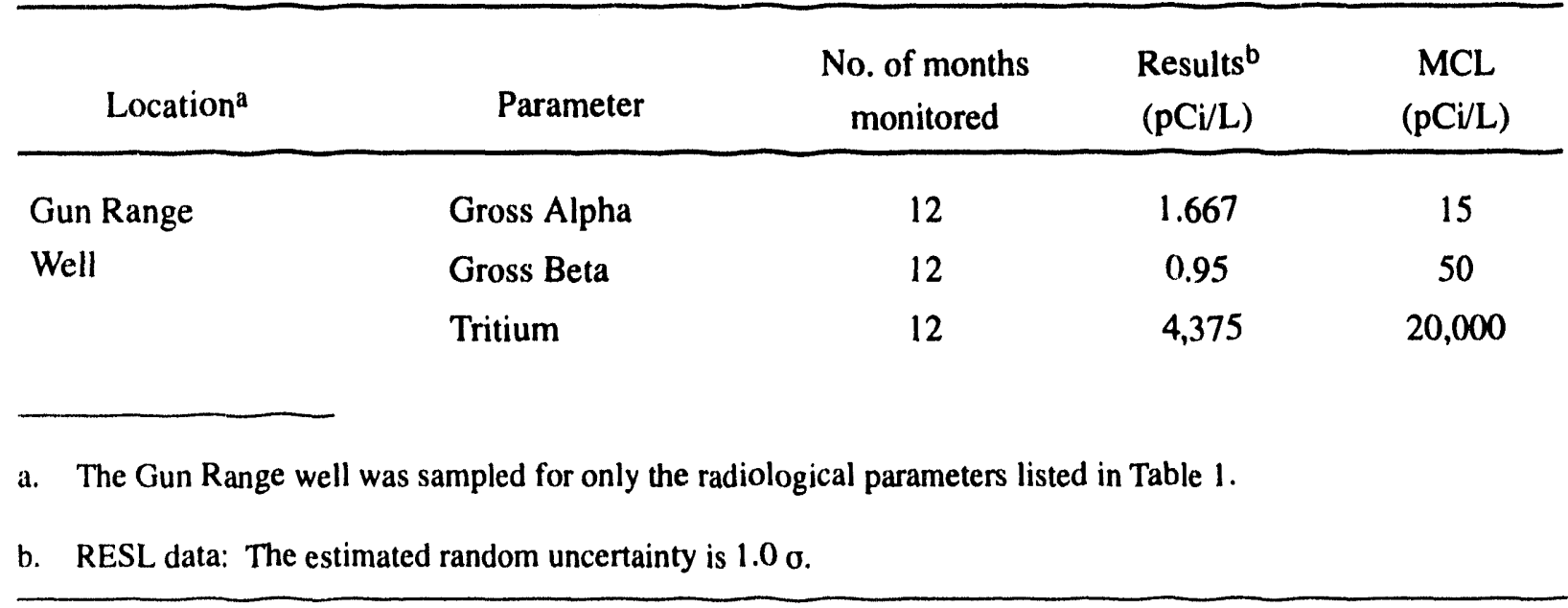


Table 19. Results of detected nonradiological parameters of the drinking water analyses for the Gun Range distribution system, B21 -608 .

\begin{tabular}{llll}
\hline & & \\
& & Results & MCL \\
Location $^{\mathrm{a}}$ & Parameter $^{\mathrm{b}}$ & $(\mathrm{mg} / \mathrm{L})$ & $(\mathrm{mg} / \mathrm{L})$ \\
\hline
\end{tabular}

Gun Range

No Detections

Distribution

System

a. The Gun Range distribution system was sampled for all parameters listed in Table 1, except for the radiological parameters.

b. Only the parameters detected are listed.

Table 20. Results of lead and copper sampling at the Gun Range distribution system during May and September of 1992.

\begin{tabular}{lllll}
\hline \multicolumn{1}{c}{ Location } & Parameter & $\begin{array}{c}\text { May Results } \\
(\mathrm{mg} / \mathrm{L})\end{array}$ & $\begin{array}{c}\text { Sept. Results } \\
(\mathrm{mg} / \mathrm{L})\end{array}$ & $\begin{array}{c}\text { MCL } \\
(\mathrm{mg} / \mathrm{L})\end{array}$ \\
\hline Gun Range & Lead & 0.0029 & 0.0038 & 0.015 \\
Distribution & Copper & 0.074 & 0.420 & 1.3 \\
System & Lead & 0.0025 & 0.0025 & 0.015 \\
& Copper & 0.048 & 0.400 & 1.3 \\
& Lead & 0.0034 & 0.0016 & 0.015 \\
& Copper & 0.190 & 0.180 & 1.3 \\
& Lead & 0.0034 & 0.0032 & 0.015 \\
& Copper & 0.370 & 0.310 & 1.3 \\
& Lead & 0.0029 & 0.0034 & 0.015 \\
& Copper & 0.200 & 0.300 & 1.3 \\
\hline
\end{tabular}


Table 21. Results of detected radiological parameters of the drinking water analyses for the Fire Station \#2 well, B16-602.

\begin{tabular}{llccc}
\hline \multicolumn{1}{c}{ Location $^{\mathrm{a}}$} & Parameter & $\begin{array}{c}\text { No. of months } \\
\text { monitored }\end{array}$ & $\begin{array}{c}\text { Results } \\
(\mathrm{pCi} / \mathrm{L})\end{array}$ & $\begin{array}{c}\mathrm{MCL} \\
(\mathrm{pCi} / \mathrm{L})\end{array}$ \\
\hline Fire Station \#2 Well & Gross Alpha & 10 & 0.89 & 15 \\
& Gross Beta & 10 & 0.60 & 50 \\
& Tritium & 10 & $<0$ & 20,000
\end{tabular}

a. The Fire Station $\# 2$ well was sampled for only the radiological parameters listed in Table 1.

b. RESL data: The estimated random uncertainty is $1.0 \mathrm{o}$.

Table 22. Results of detected nonradiological parameters of the drinking water analyses for Fire Station \#2 distribution system, B16-601.

\begin{tabular}{llc}
\hline \multicolumn{1}{c}{ Location $^{\mathrm{a}}$} & $\begin{array}{l}\text { Results } \\
(\mathrm{mg} / \mathrm{L})\end{array}$ & $\begin{array}{c}\text { MCL } \\
(\mathrm{mg} / \mathrm{L})\end{array}$ \\
\hline $\begin{array}{l}\text { Fire Station } \# 2 \\
\text { Distribution } \\
\text { System }\end{array}$ & 0.00075 & 0.2 \\
\hline $\begin{array}{l}\text { a. The Fire Station \#2 distribution system was sampled for all parameters listed in Table 1, except for the radiological, } \\
\text { lead, and copper parameters. }\end{array}$ & \\
b. Only the parameters detected are listed.
\end{tabular}


Table 25. Results of lead and copper sampling at the TRA distribution system during May and September of 1992.

\begin{tabular}{|c|c|c|c|c|}
\hline Location & Parameter & $\begin{array}{l}\text { May Results } \\
(\mathrm{mg} / \mathrm{L})\end{array}$ & $\begin{array}{l}\text { Sept. Results } \\
(\mathrm{mg} / \mathrm{L})\end{array}$ & $\begin{array}{c}\mathrm{MCL} \\
(\mathrm{mg} / \mathrm{L})\end{array}$ \\
\hline \multirow[t]{12}{*}{ TRA-679 } & Lead & 0.0 & 0.0032 & 0.015 \\
\hline & Copper & 0.430 & 0.620 & 1.3 \\
\hline & Lead & 0.0 & 0.0 & 0.015 \\
\hline & Copper & 0.370 & 0.250 & 1.3 \\
\hline & Lead & 0.0 & 0.0 & 0.015 \\
\hline & Copper & 0.350 & 0.240 & 1.3 \\
\hline & Lead & 0.0 & 0.0015 & 0.015 \\
\hline & Copper & 0.360 & 0.310 & 1.3 \\
\hline & Lead & 0.0 & 0.0 & 0.015 \\
\hline & Copper & 0.280 & 0.210 & 1.3 \\
\hline & Lead & 0.0 & 0.0 & 0.015 \\
\hline & Copper & 0.280 & 0.210 & 1.3 \\
\hline \multirow[t]{4}{*}{ TRA-680 } & Lead & 0.0017 & 0.0017 & 0.015 \\
\hline & Copper & 0.510 & 0.350 & 1.3 \\
\hline & Lead & 0.0011 & 0.0 & 0.015 \\
\hline & Copper & 0.530 & 0.450 & 1.3 \\
\hline \multirow[t]{6}{*}{ TRA-614 } & Lead & 0.004 & 0.0037 & 0.015 \\
\hline & Copper & 0.018 & 0.0095 & 1.3 \\
\hline & Lead & 0.008 & 0.011 & 0.015 \\
\hline & Copper & 0.110 & 0.120 & 1.3 \\
\hline & Lead & 0.0037 & 0.0062 & 0.015 \\
\hline & Copper & 0.083 & 0.070 & 1.3 \\
\hline \multirow[t]{2}{*}{ TRA-608 } & Lead & 0.0 & 0.0018 & 0.015 \\
\hline & Copper & 0.064 & 0.086 & 1.3 \\
\hline \multirow[t]{4}{*}{ TRA-609 } & Lead & 0.011 & 0.011 & 0.015 \\
\hline & Copper & 0.250 & 0.270 & 1.3 \\
\hline & Lead & - & 0.0039 & 0.015 \\
\hline & Copper & - & 0.230 & 1.3 \\
\hline \multirow[t]{4}{*}{ TRA-647 } & Lead & 0.0024 & 0.014 & 0.015 \\
\hline & Copper & 0.140 & 0.089 & 1.3 \\
\hline & Lead & 0.0012 & 0.0023 & 0.015 \\
\hline & Copper & 0.0064 & 0.120 & 1.3 \\
\hline
\end{tabular}


Table 25. (continued).

\begin{tabular}{lllll}
\hline Location & Parameter & $\begin{array}{c}\text { May Results } \\
(\mathrm{mg} / \mathrm{L})\end{array}$ & $\begin{array}{c}\text { Sept. Results } \\
(\mathrm{mg} / \mathrm{L})\end{array}$ & $\begin{array}{c}\text { MCL } \\
(\mathrm{mg} / \mathrm{L})\end{array}$ \\
\hline TRA-647 & Lead & 0.0029 & 0.010 & 0.015 \\
(continued) & Copper & 0.016 & 0.038 & 1.3 \\
& Lead & 0.005 & 0.0087 & 0.015 \\
& Copper & 0.077 & 0.032 & 1.3 \\
& Lead & 0.0013 & 0.0071 & 0.015 \\
& Copper & 0.014 & 0.016 & 1.3 \\
& Lead & 0.0 & - & 0.015 \\
& Copper & 0.022 & - & 1.3 \\
\hline
\end{tabular}

Table 26. Results of detected radiological parameters of the drinking water analyses for TAN/TSF \#1 well, TAN-612; TAN/TSF \#2 well, TAN-613.

\begin{tabular}{llccc}
\hline \multicolumn{1}{c}{ Location $^{\mathrm{a}}$} & \multicolumn{1}{c}{ Parameter } & $\begin{array}{c}\text { No. of months } \\
\text { monitored }\end{array}$ & $\begin{array}{c}\text { Results } \\
\text { (pCi/L) }\end{array}$ & $\begin{array}{c}\text { MCL } \\
\text { (pCi/L) }\end{array}$ \\
\hline TAN/TSF \#1 Well & Gross Alpha & 12 & 1.09 & 15 \\
& Gross Beta & 12 & 1.00 & 50 \\
& Tritium & 12 & 74.0 & 20,000 \\
TAN/TSF \#2 Well & Gross Alpha & 11 & 1.29 & 15 \\
& Gross Beta & 11 & 1.76 & 50 \\
& Tritium & 11 & 35.0 & 20,000 \\
& & & & \\
a. Wells were only sampled for VoCs and radiological parameters. & & \\
b. RESL data: The estimated random uncertainty is 1.0 0. &
\end{tabular}


Table 27. Results of detected nonradiological parameters of the drinking water analyses for the TAN/TSF \#1 well, TAN-612; TAN/TSF \#2 well, TAN-613; and distribution system, TAN-610.

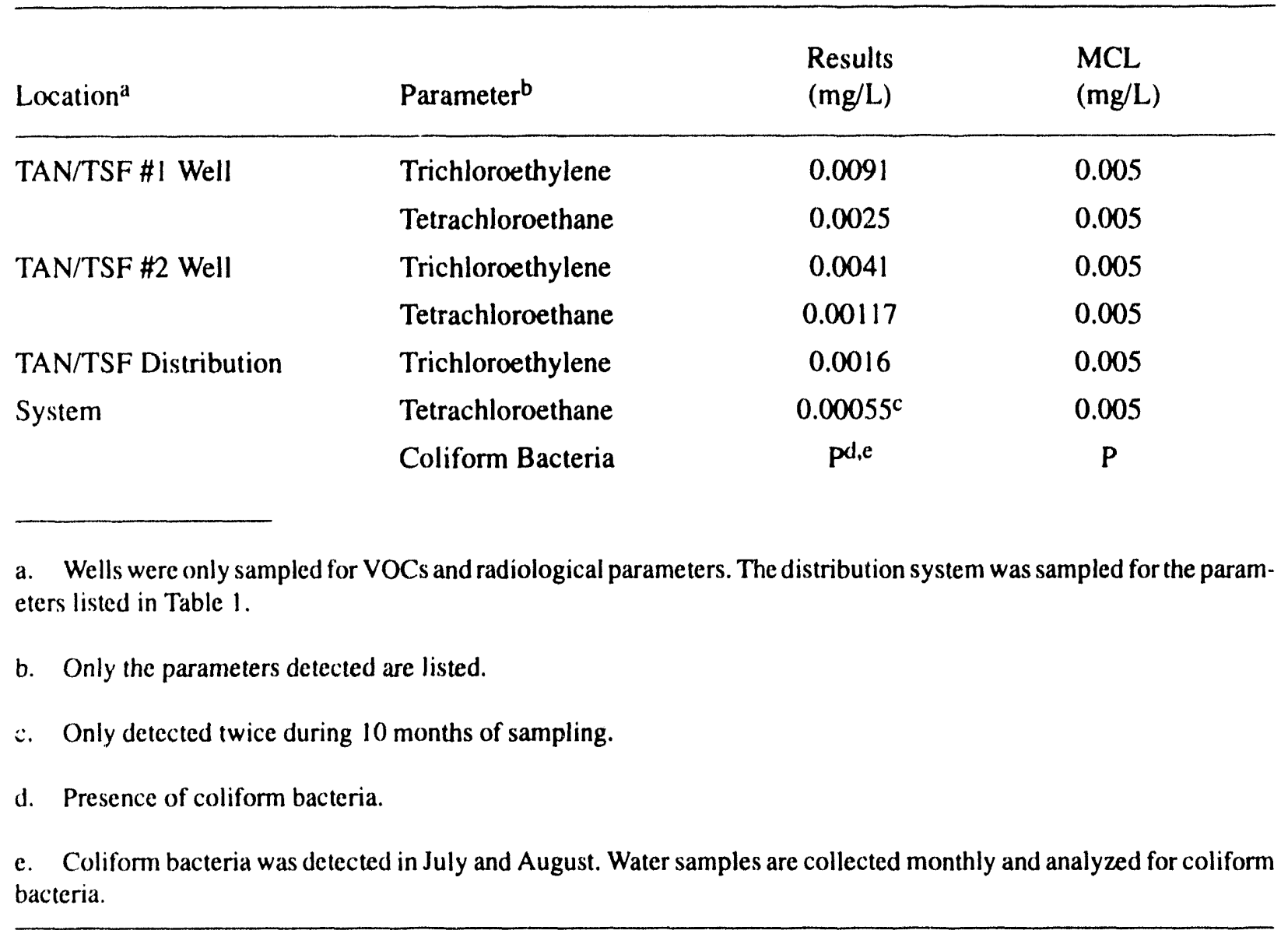


Table 28. Results of lead and copper sampling at the TAN/TSF distribution system during May and September of 1992.

\begin{tabular}{|c|c|c|c|c|}
\hline Location & Parameter & $\begin{array}{c}\text { May Results } \\
(\mathrm{mg} / \mathrm{L})\end{array}$ & $\begin{array}{c}\text { Sept. Results } \\
(\mathrm{mg} / \mathrm{L})\end{array}$ & $\begin{array}{c}\mathrm{MCL} \\
(\mathrm{mg} / \mathrm{L})\end{array}$ \\
\hline \multirow[t]{6}{*}{ TAN/TSF-653 } & Lead & 0.0034 & 0.0056 & 0.015 \\
\hline & Copper & 0.098 & 0.110 & 1.3 \\
\hline & Lead & 0.0049 & 0.0052 & 0.015 \\
\hline & Copper & 0.094 & 0.130 & 1.3 \\
\hline & Lead & 0.0052 & 0.008 & 0.015 \\
\hline & Copper & 0.095 & 0.088 & 1.3 \\
\hline \multirow[t]{4}{*}{ TAN/TSF-602 } & Lead & 0.0026 & 0.0038 & 0.015 \\
\hline & Copper & 0.120 & 0.011 & 1.3 \\
\hline & Lead & 0.0015 & 0.0015 & 0.015 \\
\hline & Copper & 0.066 & 0.010 & 1.3 \\
\hline \multirow[t]{4}{*}{ TAN/TSF-687 } & Lead & 0.0059 & 0.0038 & 0.015 \\
\hline & Copper & 0.034 & 0.034 & 1.3 \\
\hline & Lead & 0.0037 & 0.0032 & 0.015 \\
\hline & Copper & 0.015 & 0.033 & 1.3 \\
\hline \multirow[t]{4}{*}{ TAN/TSF-615 } & Lead & 0.0024 & - & 0.015 \\
\hline & Copper & 0.012 & - & 1.3 \\
\hline & Lead & 0.0024 & - & 0.015 \\
\hline & Copper & 0.011 & - & 1.3 \\
\hline \multirow[t]{2}{*}{ TAN/TSF-607 } & Lead & 0.0043 & 0.0083 & 0.015 \\
\hline & Copper & 0.018 & 0.020 & 1.3 \\
\hline \multirow[t]{2}{*}{ TAN/TSF-653 } & Lead & 0.0024 & 0.0025 & 0.015 \\
\hline & Copper & 0.069 & 0.093 & 1.3 \\
\hline
\end{tabular}


Table 29. Results of detected radiological parameters of the drinking water analyses for TAN/CTF \#I well, TAN-632; TAN/CTF \#2 well, TAN-639.

\begin{tabular}{llccc}
\hline \multicolumn{1}{c}{ Location $^{\mathrm{a}}$} & Parameter & $\begin{array}{c}\text { No. of months } \\
\text { monitored }\end{array}$ & $\begin{array}{c}\text { Results } \\
(\mathrm{pCi} / \mathrm{L})\end{array}$ & $\begin{array}{c}\text { MCL } \\
(\mathrm{pCi} / \mathrm{L})\end{array}$ \\
\hline TAN/CTF \#1 Well & Gross Alpha & 12 & 1.28 & 15 \\
& Gross Beta & 12 & 1.91 & 50 \\
& Tritium & 12 & $<0$ & 20,000 \\
TAN/CTF \#2 Well & Gross Alpha & 12 & 1.12 & 15 \\
& Gross Beta & 12 & 1.44 & 50 \\
& Tritium & 12 & $<0$ & 20,000 \\
& & & & \\
a. Wells were only sampled for radiological constituents listed in Table 1. & & \\
b. RESL data: The estimated random uncertainty is $1.0 \mathrm{o}$. & & \\
\hline
\end{tabular}

Table 30. Results of detected nonradiological parameters of the drinking water analyses for TAN/CTF distribution system, TAN-614.

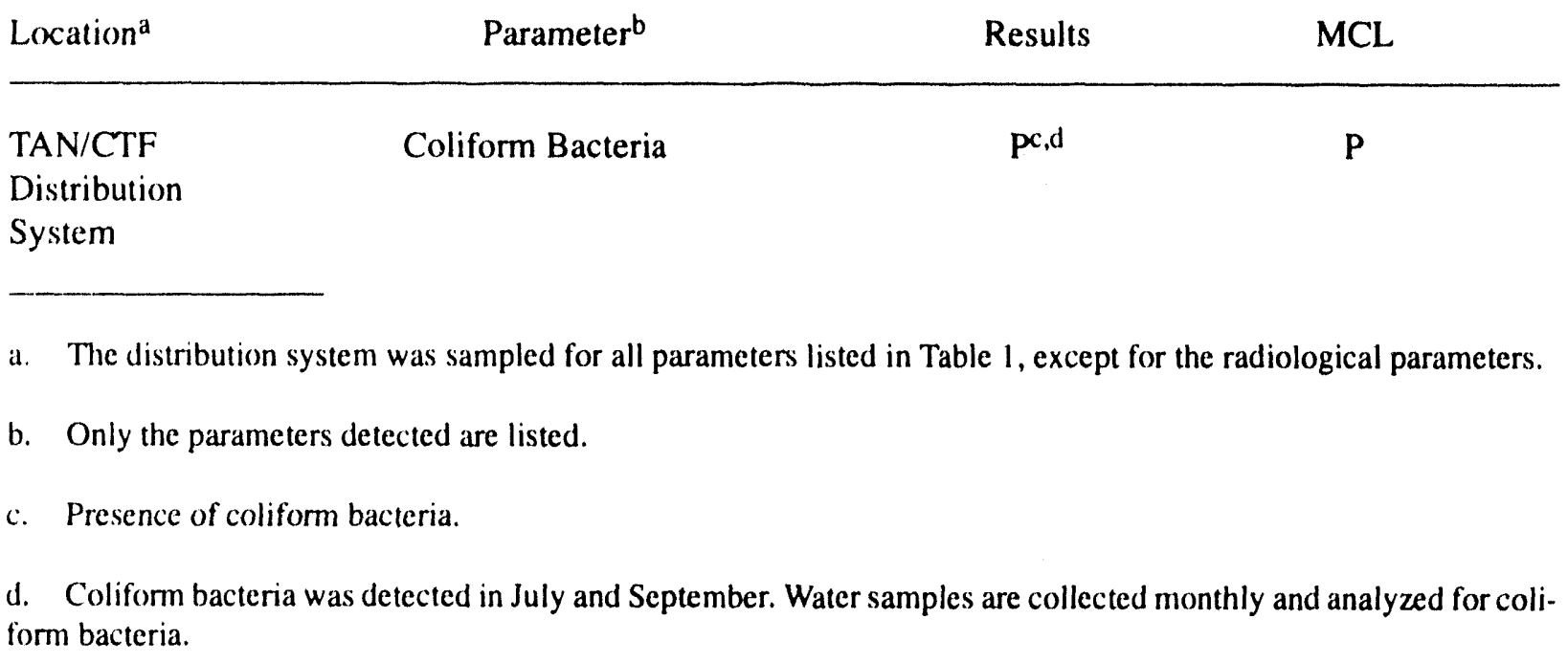


Table 31. Results of lead and copper sampling at the TAN/CTF distribution system during May and September of 1992.

\begin{tabular}{cllll}
\hline Location & Parameter & $\begin{array}{c}\text { May Results } \\
(\mathrm{mg} / \mathrm{L})\end{array}$ & $\begin{array}{c}\text { Sept. Results } \\
(\mathrm{mg} / \mathrm{L})\end{array}$ & $\begin{array}{c}\text { MCL } \\
(\mathrm{mg} / \mathrm{L})\end{array}$ \\
\hline TAN/CTF-678 & Lead & 0.0014 & 0.0018 & 0.015 \\
& Copper & 0.097 & 0.110 & 1.3 \\
& Lead & 0.0029 & 0.0037 & 0.015 \\
& Copper & 0.074 & 0.089 & 1.3 \\
& Lead & 0.0023 & 0.0029 & 0.015 \\
& Copper & 0.076 & 0.065 & 1.3 \\
& Lead & 0.0012 & 0.0017 & 0.015 \\
& Copper & 0.097 & 0.094 & 1.3 \\
& Lead & 0.0029 & 0.0026 & 0.015 \\
& Copper & 0.100 & 0.130 & 1.3 \\
& Lead & 0.0033 & 0.0023 & 0.015 \\
& Copper & 0.070 & 0.079 & 1.3 \\
& Lead & 0.002 & 0.0014 & 0.015 \\
& Copper & 0.110 & 0.120 & 1.3 \\
& Lead & 0.0031 & 0.0 & 0.015 \\
& Copper & 0.150 & 0.120 & 1.3 \\
& Lead & 0.0024 & 0.0018 & 0.015 \\
& Copper & 0.820 & 0.074 & 1.3 \\
\hline
\end{tabular}


Table 32. Results of detected radiological parameters of the drinking water analyses for TAN/WRRTF well, TAN-644.

\begin{tabular}{llccc}
\hline \multicolumn{1}{c}{ Location $^{\mathrm{a}}$} & Parameter & $\begin{array}{c}\text { No. of months } \\
\text { monitored }\end{array}$ & $\begin{array}{c}\text { Results } \\
(\mathrm{pCi} / \mathrm{L})\end{array}$ & $\begin{array}{c}\text { MCL } \\
(\mathrm{pCi} / \mathrm{L})\end{array}$ \\
\hline TAN/WRRTF Well & Gross Alpha & 11 & 1.32 & 15 \\
& Gross Beta & 11 & 1.83 & 50 \\
& Tritium & 11 & $<0$ & 20,000 \\
& & & \\
a. The TAN/WRRTF well was sampled for only the radiological parameters listed in Table 1. \\
b. RESL data: The estimated random uncertainty is $1.0 \mathrm{or}$
\end{tabular}

Table 33. Results of detected nonradiological parameters of the drinking water analyses for TAN/WRRTF distribution system, TAN-645.

\begin{tabular}{|c|c|c|c|}
\hline Location $^{\mathrm{a}}$ & Parameter $^{b}$ & $\begin{array}{l}\text { Results } \\
(\mathrm{mg} / \mathrm{L})\end{array}$ & $\begin{array}{l}\mathrm{MCL} \\
(\mathrm{mg} / \mathrm{L})\end{array}$ \\
\hline $\begin{array}{l}\text { TAN/WRRTF } \\
\text { Distribution } \\
\text { System }\end{array}$ & $\begin{array}{l}\text { Trichloroethylene } \\
\text { Tetrachloroethane }\end{array}$ & $\begin{array}{l}0.00658 \\
0.00245\end{array}$ & $\begin{array}{l}0.005 \\
0.005\end{array}$ \\
\hline \multicolumn{4}{|c|}{$\begin{array}{l}\text { a. The TAN/WRRTF distribution system was sampled for only VOCs and coliform bacteria. } \\
\text { b. Only the parameters detected are listed. }\end{array}$} \\
\hline
\end{tabular}


Table 34. Results of detected radiological parameters of the drinking water analyses for RWMC well, WMF-603.

\begin{tabular}{llccc}
\hline Location $^{\natural}$ & Parameter & $\begin{array}{c}\text { No. of months } \\
\text { monitored }\end{array}$ & $\begin{array}{c}\text { Results } \\
(\mathrm{pCi} / \mathrm{L})\end{array}$ & $\begin{array}{c}\mathrm{MCL} \\
(\mathrm{pCi} / \mathrm{L})\end{array}$ \\
\hline \multirow{2}{*}{ RWMC Well } & Gross Alpha & 12 & 1.65 & 15 \\
& Gross Beta & 12 & 1.13 & 50 \\
& Tritium & 12 & 1,567 & 20,000
\end{tabular}

a. The RWMC well was sampled for VOCs and radiological parameters listed on Table 1.

b. RESL data: The estimated random uncertainty is 1.00 .

Table 35. Results of detected nonradiological parameters of the drinking water analyses for RWMC well and distribution system, WMF-603.

\begin{tabular}{llclc}
\hline \multicolumn{1}{c}{ Location $^{\mathrm{a}}$} & \multicolumn{1}{c}{ Parameter $^{\mathrm{b}}$} & $\begin{array}{c}\text { No. of months } \\
\text { monitored }\end{array}$ & $\begin{array}{c}\text { Results } \\
(\mathrm{mg} / \mathrm{L})\end{array}$ & $\begin{array}{c}\text { MCL } \\
(\mathrm{mg} / \mathrm{L})\end{array}$ \\
\hline RWMC, 603 Well & $\begin{array}{l}\text { Carbon Tetrachloride } \\
\text { Trichloroethylene }\end{array}$ & 12 & 0.0017 & 0.005 \\
& $\begin{array}{l}\text { Carbon Tetrachloride } \\
\text { RWMC }\end{array}$ & 12 & 0.0009 & 0.005 \\
$\begin{array}{l}\text { Distribution } \\
\text { System }\end{array}$ & Trichloroethylene & 12 & 0.00073 & 0.005 \\
& & & 0.0006 & 0.005 \\
a. The distribution system was sampled for all parameters listed on Table 1, except for the radiological parameters. \\
b. Only the parameters detected are listed.
\end{tabular}


Table 36. Results of lead and copper sampling at the RWMC distribution system during May and September of 1992.

\begin{tabular}{|c|c|c|c|c|}
\hline Location & Parameter & $\begin{array}{l}\text { May Results } \\
(\mathrm{mg} / \mathrm{L})\end{array}$ & $\begin{array}{l}\text { Sept. Results } \\
(\mathrm{mg} / \mathrm{L})\end{array}$ & $\begin{array}{c}\mathrm{MCL} \\
(\mathrm{mg} / \mathrm{L})\end{array}$ \\
\hline \multirow[t]{4}{*}{ RWMC-604 } & Lead & 0.0019 & 0.0018 & 0.015 \\
\hline & Copper & 0.0056 & 0.0084 & 1.3 \\
\hline & Lead & 0.0027 & 0.0018 & 0.015 \\
\hline & Copper & 0.005 & 0.015 & 1.3 \\
\hline \multirow[t]{4}{*}{ RWMC-601 } & Lead & 0.0015 & 0.0012 & 0.015 \\
\hline & Copper & 0.0079 & 0.012 & 1.3 \\
\hline & Lead & 0.0021 & 0.0 & 0.015 \\
\hline & Copper & 0.031 & 0.025 & 1.3 \\
\hline \multirow[t]{4}{*}{ RWMC-617 } & Lead & 0.003 & 0.0037 & 0.015 \\
\hline & Copper & 0.083 & 0.130 & 1.3 \\
\hline & Lead & 0.0045 & - & 0.015 \\
\hline & Copper & 0.240 & - & 1.3 \\
\hline \multirow[t]{6}{*}{ RWMC-613 } & Lead & 0.0022 & 0.0019 & 0.015 \\
\hline & Copper & 0.041 & 0.089 & 1.3 \\
\hline & Lead & 0.0025 & - & 0.015 \\
\hline & Copper & 0.049 & - & 1.3 \\
\hline & Lead & 0.0023 & - & 0.015 \\
\hline & Copper & 0.069 & - & 1.3 \\
\hline \multirow[t]{6}{*}{ RWMC-610 } & Lead & - & 0.0024 & 0.015 \\
\hline & Copper & - & 0.099 & 1.3 \\
\hline & Lead & - & 0.0051 & 0.015 \\
\hline & Copper & - & 0.130 & 1.3 \\
\hline & Lead & - & 0.0029 & 0.015 \\
\hline & Copper & - & 0.140 & 1.3 \\
\hline
\end{tabular}




$$
\longrightarrow
$$




\section{REFERENCES}

1. B. D. Lewis and R. G. Jensen, Hydrologic Conditions at the Idaho National Engineering Laboratory, Idaho: 1979-1981 Update, U.S. Geological Survey, Open-File Report 84-230, 1984.

2. J. B. Robertson, Digital Modeling of Radioactive and Chemical Water Transport in the Snake River Plain Aquifer at the National Reactor Testing Station, Idaho, IDO-22054, U.S. Geological Survey, Open-File Report, 1974.

3. J. B. Robertson, R. Schoen, and J. T. Barraclough, The Influence of Liquid Waste Disposal on the Geochemistry of Water at the National Reactor Testing Station, Idaho: 1952-1970, IDO-22053, U.S. Geological Survey, 1974.

4. Idaho Regulations for Public Drinking Water Systems, IDAPA 16.01.08000-.08999, December 5, 1992.

5. Code of Federal Regulations, 40 CFR 141-143, "Protection of the Environment," Office of the Federal Register, February 1, 1993.

6. EPA Method 524.2 (revision 3), "Methods for the Determination of Organic Compounds in Drinking Water Enviornmental Monitoring Systems Laboratory," Office of Research and Development, U.S. Environmental Portection Agency, December 1988.

7. Drinking Water Monitoring Handbook for Operational Facilities at the Idaho National Engineering Laboratory, Environmental Monitoring Program, EGG-EV-9155, 1988.

8. Standard Methods for the Examination of Water and Waste Water, 18th edition, American Public Health Association, American Water Works Association, and Water Pollution Control Federation, 1992. 


\section{Appendix A}

\section{Quality Assurance}

$$
\text { A-1 }
$$


A-2

A-2

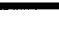




\section{Appendix A}

\section{Quality Assurance}

\section{RADIOLOGICAL MEASUREMENTS}

The objectives of the Quality Assurance (QA) Program for the DWP at EG\&G Idaho facilities at the INEL are to: (a) identify deficiencies in the sampling and measurement processes so that corrective action can be taken, and (b) ensure that the analytical results of the DWP are valid.

Specific elements used to ensure that the objectives of the QA Program are met include:

- Organizational structure and responsibilities of managerial and program personnel

- Documented procedures that describe the materials and equipment needed, specific precautions, prerequisites, and step-by-step sampling procedures for monitoring activities

- Document-control processes for the preparation, revision, and approval of procedures

- Maintenance of records pertaining to monitoring activities, such as planning documents, data sheets, sample results, and calibration records
- Proper calibration and preventive maintenance

- Analyses of quality control (QC) samples (known standards, blank samples, split samples and replicates) to assess accuracy and precision of monitoring results

- Planned and periodic self-assessments.

The DWP determines whether the analytical results for the control samples are acceptable. The activity in the QC sample, and type of analysis are taken into consideration. Each set of known values and laboratory results receives individual consideration. QC samples representative of the DWP water samples are submitted for each analysis type. 


\section{NONRADIOLOGICAL MEASUREMENTS}

The DWP follows the guidance provided in QAMS-001 80). ${ }^{A-1}$ This ensures that the program provides adequate $\mathrm{QC}$ practices to verify the representativeness of the sampling methods and the integrity of the samples themselves. Other supporting documentation includes calibration requirements for field instruments, and criteria for ensuring that field personnel are properly trained.

The portion of the QA program dealing with analytical concerns is designed to assure that data of a known quality are produced by the analyses. QC practices are used to identify and resolve any problems caused by possible matrix effects, contamination, or instrument malfunction. Addressed and documented in the QA program are such issues as intended data use, training/qualification of personnel, organization and responsibilities, corrective action in case of an out-of-control operation, calibration and standardization of analytical instrumentation, sampling and analytical methodology, source and submission of QC samples, sample and data tracking chain of custody, and auditevaluation programs. The standard operating procedures that document operation of the QA Program are appended to the Quality Program Plan. ${ }^{\mathrm{A}-2}$

For all chemical measurements (excluding radiochemical procedures) the uncertainty in an analytical result for a single sample is created by a combination of the following portions of the analytical process:

\section{Sample heterogeneity}

2. Analysis equipment calibration

3. Analysis equipment noise

4. Laboratory contamination

5. Sample contamination
6. Analyte extraction efficiency

7. Chemical interferences.

Laboratory analysis procedures are designed to minimize the uncertainties as much as practical. The uncertainties are largely a result of limitations in the analytical methods and are acceptable by approved EPA methods, including EPA Contract Laboratory Program methods.

Determining the uncertainty of each sample is not usually practical, so the normal approach is to conduct QC measurements on 10 to $20 \%$ of the samples and assume that the observed uncertainty applies to all samples. This is a valid assumption as long as monitoring of the QC results indicates results are consistently within established control limits. The control limits then indicate the maximum uncertainty of each component of the measurements.

Data undergoes a validation for conformance to three main program integrity areas: sample integrity, method validity and adherence to program data quality objectives. Logbook entries are compared against the chain of custody forms and laboratory deliverables verifying that requested analyses were performed and proper preservation techniques were employed. Next the analytical method is validated by reviewing such quality control indicators as holding time, calibrations, associated blanks, and associated laboratory control standards. Finally the data is compared against program data quality objectives which have been set to provide a level of false positives of $5 \%$ at the regulatory level based on historical method combined accuracy and precision.

Analytical uncertainty does not include uncertainties introduced by field-sampling variability and by natural spatial and temporal variability of the medium sampled in the field. A true statistical evaluation of these uncertainties can be made only by collection and analysis of multiple samples in both space and time from each sampling site. Sampling bias or contamination of samples 
can also greatly increase the uncertainty associated with the analytical result for a sample. These uncertainties can and often do exceed the analytical uncertainty. The sampling and natural field variability components of uncertainty should be established, or at least estimated, and added to analytical uncertainty before any analytical results are assumed to represent concentrations at the site of collection.

\section{Conclusion}

The data in this report have met the quality assurance objectives of the program (see Appendix A). Laboratories that were used during 1992 successfully passed a quality assurance and technical audit before samples were sent to them.

Note: Since the EPA audited both RESL and District 7 Health Department for laboratory certification for drinking water analyses, EG\&G Idaho did not audit these two laboratories. 


\section{REFERENCES}

A-1. QAMS-001, Quality Assurance Management Manual, U.S. Environmental Protection Agency, 1980.

A-2. Quality Program Plan for Environmental Monitoring, Environmental Monitoring Unit, QPP-029, May 1991. 


\section{Appendix B \\ EG\&G Idaho Facilities Water Distribution Systems and \\ Production Well Descriptions}




$$
\text { B-2 }
$$




\section{Appendix B}

\section{EG\&G Idaho Facilities Water Distribution Systems and Production Well Descriptions}

\section{EG\&G Idaho Facilities Water Distribution Systems}

1. Central Facilities Area, CFA-641

2. Main Gate, B27-603

3. Power Burst Facility, PBF-602

4. Experimental Breeder Reactor I, EBR-60I

5. Gun Range, B21-608

6. Fire Station \#2, B16-601

7. Test Reactor Area, TRA-608

8. Test Area North/Technical Support Facility, TAN-610

9. Test Area North/Containment Test Facility, TAN-614

10. Test Area North/Water Reactor Research Test Facility, TAN-645

11. Radioactive Waste Management Complex, WMF-603 


\section{CFA \#1 Production Well}

USGS Site ID\#: 433204112562001

State of Idaho PWS\#: 6120008

Location: CFA-651

Depth of hole: $685^{\prime}$

Depth of well: 639'

Depth to water: $468^{\circ}$

Date of completion: July 1942

Size and depth of casing: 16", 6 to $440^{\prime}$

Casing material: Steel

Pump information: Submersible, GPM - 650, horsepower - 150

Media: Aqueous

Special equipment: None

Access required: None

Support required: Operator (mechanic)

Point of contact: (CFA) Facilities and Management Craft Operation

Minimum purge time: 8 minutes 


\section{CFA \#2 Production Well}

USGS Site ID\#: 433144112563501

State of Idaho PWS\#: 6120008

Location: CFA-642

Depth of hole: $681^{\prime}$

Depth of well: $681^{\prime}$

Depth to water: $471^{\prime}$

Date of completion: May 1944

Size and depth of casing: $20^{\prime \prime}, 6$ to $68^{\prime} ; 16 ", 6$ to $681^{\prime}$

Casing material: Steel

Pump information: Submersible, GPM -600 , horsepower -125

Media: Aqueous

Special equipment: None

Access required: None

Support required: Operator (mechanic)

Point of contact: (CFA) Facilities and Management Craft Operation

Minimum purge time: 11 minutes 


\section{Main Gate Production Well}

USGS Site ID\#: 433042112535101

State of Idaho PWS\#: 6120015

Location: B27-605

Depth of hole: $644^{\prime}$

Depth of well: 644'

Depth to water: $489^{\prime}$

Date of completion: January 5, 1985

Size and depth of casing: 6",0 to 533'; 8", 0 to $181^{\prime}$

Casing material: Steel

Pump information: Submersible, GPM - 20, Horsepower - 5

Media: Aqueous

Special equipment: None

Access required: None

Support required: Operator (mechanic)

Point of contact: (CFA) Facilities and Management Craft Operation

Minimum purge time: 34 minutes 


\section{PBF \#1 Production Woll}

USGS Site ID\#: 433252112520301

State of Idaho PWS\#: 6120019

Location: PBF-602

Depth of hole: 653 '

Depth of well: 653'

Depth to water: $456^{\prime}$

Date of completion: February 4, 1955

Size and depth of casing: 14", 0 to 653'

Casing material: Steel

Pump information: Submersible, GPM - 400, horsepower -80

Media: Aqueous

Special equipment: None

Access required: None

Support required: Operator

Point of contact: (CFA) Facilities and Management Craft Operation

Minimum purge time: 12 minutes 


\section{PBF \#2 Production Well}

USGS site ID\#: 433247112515201

State of Idaho PWS\#: 6120019

Location: PBF-614

Depth of hole: $1217^{\prime}$

Depth of well: $1217^{\prime}$

Depth to water: $463^{\prime}$

Date of completion: April 14, 1960

Size and depth of casing: $12 " 573$ to $950^{\prime} ; 16^{\prime \prime}, 0$ to 767'

Casing material: Steel

Pump information: Line-shaft, GPM - 800, horsepower - 200

Media: Aqueous

Special equipment: None

Access required: None

Support required: Operator (mechanic)

Point of contact: (CFA) Facilities and Management Craft Operation

Minimum purge time: 22 minutes 


\section{EBR $\dashv$ Production Well}

United States Geological Survey (USGS) Site ID\#: 433051113002601

State of Idaho Public Water System Number (PWS\#): 6120009

Location: EBR-I, EBR-711

Depth of hole: 1075 ,

Depth of well: 1075'

Depth to water: 596'

Date of completion: May 1949

Size and depth of casing: 18", 6 to 750'

Casing material: Steel

Pump information: Submersible, GPM - 800, horsepower - 200

Media: Aqueous

Special equipment: None

Access required: Confined Space Permit

Support required: Operator (mechanic)

Point of contact: (CFA) Facilities and Management Craft Operation

Minimum purge time: 24 minutes 


\section{Gun Range Production Well}

USGS Site ID\#: GUN RANGE

State of Idaho PWS\#: $61200: 5$

Location: B21-607

Depth of hole: $626^{\circ}$

Depth of well: 620'

Depth to water: 508'

Date of completion: January 1990

Size and depth of casing: 5", 305 to $625^{\prime} ; 6^{\prime \prime}, 0$ to $310^{\prime} ; 8^{\prime \prime}, 0$ to 150 ';

Casing material: Steel

Pump information: Submersible, GPM -20 , horsepower - 5

Media: Aqueous

Special equipment: None

Access required: Contact Range Officer

Support required: Operator (mechanic)

Point of contact: (CFA) Facilities and Management Craft Operation

Minimum purge time: 18 minutes 


\section{Fire Station \#2 (Inactive)}

USGS Site ID\#: 433548112562301

State of Idaho PWS\#: 6120011

Location: Fire St.\#2, B16-602

Depth of hole: 518'

Depth of well: 516 '

Depth to water: 420'

Date of completion: December 11, 1957

Size and depth of casing: 10", 0 to 516'

Casing material: Steel

Pump information: Schedule 40 pipe, GPM -400 , horsepower - 75

Media: Aqueous

Special equipment: None

Access required: None

Support required: Operator (mechanic)

Point of contact: (CFA) Facilities and Management Craft Operation

Minimum purge time: 3 minutes 


\section{TRA \#1 Production Well}

USGS Site ID\#: 433521112573801

State of Idaho PWS\#: 6120020

Location: TRA-601

Depth of hole: 600 '

Depth of well: 600'

Depth to water: 453'

Date of completion: February 1, 1950

Size and depth of casing: 18", 0 to 600'

Casing material: Wrought iron

Pump information: Line-shaft, GPM - 3200, horsepower -700

Media: Aqueous

Special equipment: Hearing protection

Access required: None

Support required: Operator

Point of contact: (TRA) Utility Operators

Minimum purge time: 2 minutes 
TRA \#3 Production Well

USGS Site ID\#: 433522112573501

State of Idaho PWS\#: 6120020

Location: TRA-650

Depth of hole: 602'

Depth of well: 602'

Depth to water: 456'

Date of completion: March 17, 1957

Size and depth of casing: 20", 0 to 597'

Casing material: Steel

Pump information: Line-shaft, GPM - 3800, horsepower -700

Media: Aqueous

Special equipment: Hearing protection

Access required: None

Support required: Operator

Point of contact: (TRA) Utility Operators

Minimum purge time: 2 minutes 


\section{TRA \#4 Production Well}

USGS Site ID\#: 433521112574201

State of Idaho PWS\#: 6120020

Location: TRA-672

Depth of hole: 975 '

Depth of well: $965^{\prime}$

Depth to water: 463'

Date of completion: July 25, 1963

Size and depth of casing: 16", 705 to 970' ; 18", 300 to $765^{\prime} ; 20$ ", 0 to $418^{\prime} ; 26^{\prime \prime}, 0$ to $50^{\prime}$

Casing material: Steel

Pump information: Line-shaft, GPM - 2000, horsepower - 350

Media: Aqueous

Special equipment: Hearing protection

Access required: None

Support required: Operator

Point of contact: (TRA) Utility Operators

Minimum purge time: 9 minutes 


\section{TSF \#1 Production Well}

USGS Site ID\#: 435056112420001

State of Idaho PWS\#: 6120021

Location: TAN-612

Depth of hole: 365 '

Depth of well: 360 '

Depth to water: 208'

Date of completion: January 26, 1953

Size and depth of casing: 16", 0 to $365^{\prime}$

Casing material: Steel

Pump information: Line-shaft, GPM - 1000, horsepower -80

Media: Aqueous

Special equipment: None

Access required: None

Support required: Operator

Point of contact: (TAN) Utility Operators

Minimum purge time: 5 minutes 
TSF \#2 Production Well

USGS Site ID\#: 435100112420701

State of Idaho PWS\#: 6120021

Location: TAN-613

Depth of hole: 346 '

Depth of well: 340 '

Depth to water: $211^{\prime}$

Date of completion: August 29, 1953

Size and depth of casing: 16 ", 0 to $345^{\prime}$

Casing material: Steel

Pump information: Line-shaft, GPM - 1000, horsepower - 80

Media: Aqueous

Special equipment: None

Access required: None

Support required: Operator

Point of contact: (TAN) Utility Operators

Minimum purge time: 4 minutes 


\section{CTF \#1 Production Well}

USGS Site ID\#: 435120112432101

State of Idaho PWS\#: 6120013

Location: TAN-632

Depth of hole: 339 '

Depth of well: 330 '

Depth to water: 199'

Date of completion: November 1, 1957

Size and Depth of casing: 18", 0 to 330'

Casing material: Steel

Pump information: Line-shaft, GPM - 1000, horsepower -100

Media: Aqueous

Special equipment: None

Access required: None

Support required: Operator

Point of contact: (TAN) Utility Operators

Minimum purge time: 5 minutes 


\section{CTF \#2 Production Well}

USGS Site ID\#: 435119112431801

State of Idaho PWS\#: 6120013

Location: TAN-639

Depth of hole: 462'

Depth of well: 455 ,

Depth to water: 200'

Date of completion: April 1, 1958

Size and depth of casing: 18", 0 to $455^{\prime}$

Casing material: Steel

Pump information: Line-shaft, GPM - 1000, horsepower - 100

Media: Aqueous

Special equipment: None

Access required: None

Support required: Operator

Point of contact: (TAN) Utility Operators

Minimum purge time: 10 minutes 


\section{WRRTF Production Well (Inactive)}

USGS Site ID\#: 434952112411301

State of Idaho PWS\#: 6120014

Location: TAN-644

Depth of hole: $309^{\prime}$

Depth of well: 309'

Depth to water: 209'

Date of completion: July 12, 1956

Size and depth of casing: 8", 0 to 309'

Casing material: Steel

Pump information: Line-shaft, GPM-400, horse-

power -50

Media: Aqueous

Special equipment: None

Access required: None

Support required: Operator (mechanic)

Point of contact: (TAN) Utility Operators

Minimum purge time: 2 minutes 


\section{RWMC Production Well}

USGS Site ID\#: 433002113021701

State of Idaho PWS\#: 6120018

Location: Waste Management Facility (WMF), WMF-603

Depth of hole: $685^{\prime}$

Depth of well: 685 '

Depth to water: 568'

Date of completion: November 1974

Size and depth of casing: 10 ", 0 to $658^{\prime} ; 14^{\prime \prime}, 0$ to 562'; 18", 0 to $108^{\prime}$

Casing material: Steel

Pump information: Line-shaft, GPM-240, horsepower - 75

Media: Aqueous

Special equipment: None

Access required: None

Support required: Operator (mechanic)

Point of contact: (RWMC) Facilities and Management Craft Operation

Minimum purge time: 6 minutes 

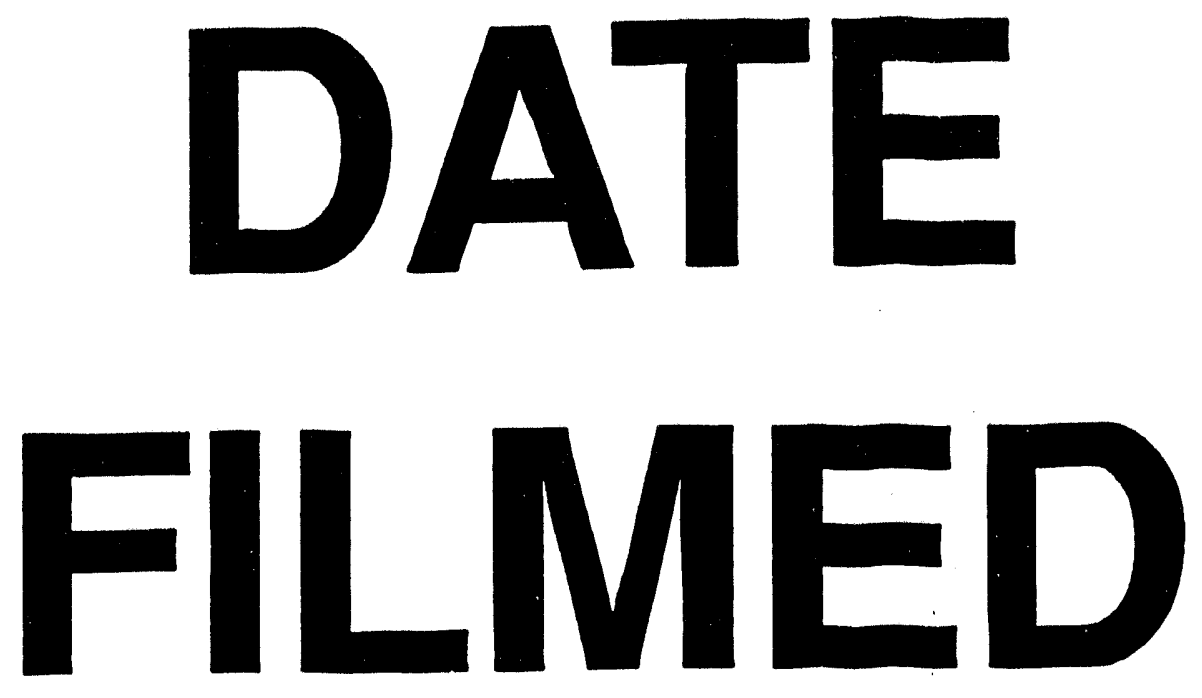

$12 / 22 / 93$
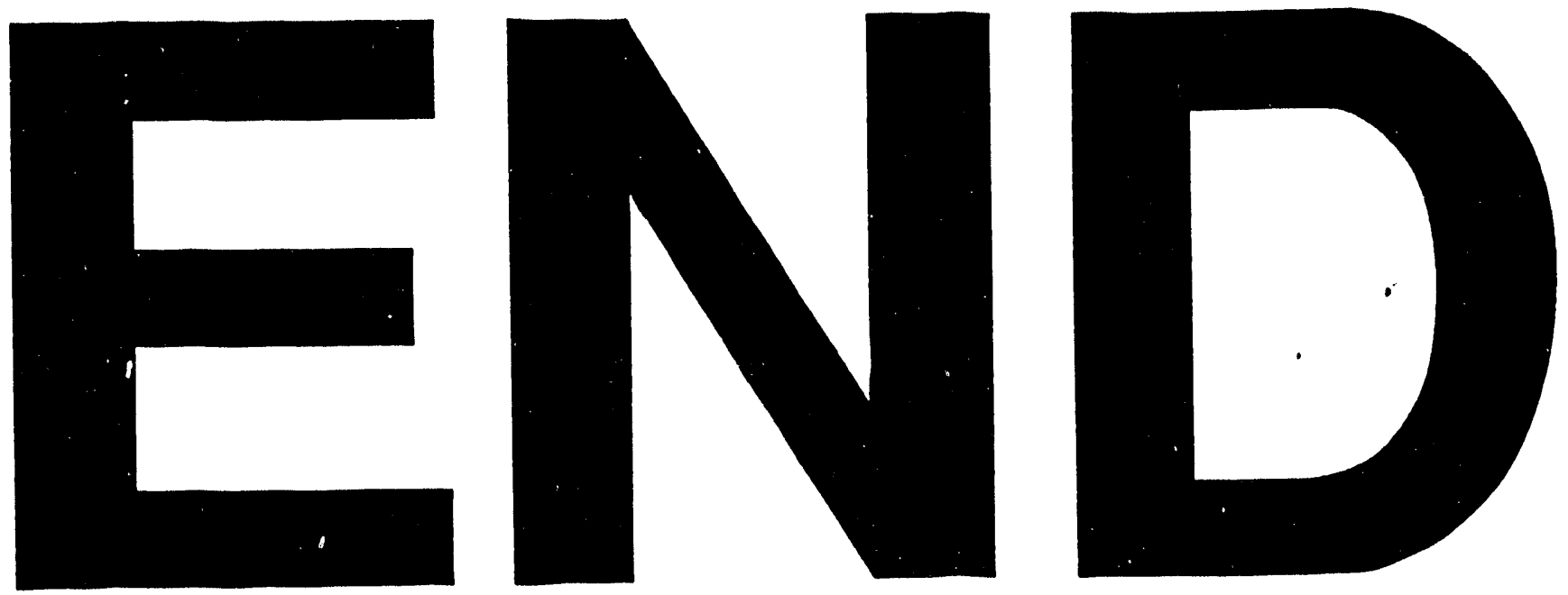
